\title{
Exploring Multidimensional Poverty in China: 2010 to 2014
}

Sabina Alkire, ${ }^{*}$ Yangyang Shen ${ }^{* *}$

July 2017

\section{This is an Author's Accepted Manuscript (AAM) of a paper which is forthcoming in Research on Economic Inequality, volume 25, 2017.}

\begin{abstract}
Most poverty research has explored monetary poverty. This paper presents and analyzes the global Multidimensional Poverty Index (MPI) estimations for China. Using China Family Panel Studies (CFPS), we find China's global MPI was 0.035 in 2010 and decreased significantly to 0.017 in 2014. The dimensional composition of MPI suggests that nutrition, education, safe drinking water, and cooking fuel contribute most to overall non-monetary poverty in China. Such analysis is also applied to subgroups, including geographic areas (rural/urban, east/central/west, provinces), as well as social characteristics such as gender of the household head, age, education level, marital status, household size, migration status, ethnicity, and religion. We find the level and composition of poverty differs significantly across certain subgroups. We also find high levels of mismatch between monetary and multidimensional poverty at the household level, which highlights the importance of using both complementary measures to track progress in eradicating poverty.
\end{abstract}

Keywords: China, multidimensional poverty, poverty, disaggregation, mismatch

JEL classification: I3, I32

* Director of Oxford Poverty and Human Development Initiative (OPHI), University of Oxford.

sabina.alkire@qeh.ox.ac.uk

** Post-doc at BNU Business School, Beijing Normal University. syy@bnu.edu.cn 


\section{Motivation and Literature Review}

\subsection{Motivation}

When the People's Republic of China was founded in 1949, China was one of the poorest countries in the world. According to the U.N. Economic and Social Commission for Asia and the Pacific (ESCAP), China's national income per capita was 27 dollars in 1949, less than two-thirds of the average per capita income in Asia of 44 dollars and less than half of India's per capita income of 57 dollars. Before China's reform and opening (1979), 250 million people (30.7\% of the population) ${ }^{1}$ were living in severe income poverty. But this tide turned after the 1980s. During 1978-2010, 250 million people moved out of monetary poverty by national definitions; 439 million people moved out of extreme income poverty from 1990 to 2011 using the $\$ 1.25 /$ day standard (Millennium Development Goals Report 2015). In 2015, the official published rural poverty national headcount ratio was $5.7 \% .^{2}$

Many studies have explored how China achieved this remarkable transformation. Economic growth is no doubt one factor. ${ }^{3}$ At the same time, China's development-oriented anti-poverty policy played an important role as well. Impact evaluation ${ }^{4}$ and analyses of causal relationships ${ }^{5}$ have been conducted, but these have explored the dramatic changes in monetary poverty. This paper has a different focus. We consider poverty to be multidimensional, and so we explore the evolution of multidimensional poverty in non-monetary dimensions. While we cannot go back to 1978 to find out how many millions of people in China have been lifted out of multidimensional poverty, we can and do rigorously explore the evolution of multidimensional poverty from 2010-2014.

The theoretical framework for our paper follows Amartya Sen's capability approach (Sen, 1999). According to Sen, poverty and development are best conceptualized in the space of capabilities, which show what each person is able to do and be. Poverty shows how people's capabilities are constricted. Poverty is multidimensional because people's lives are 'battered and diminished in many ways'. But why should Sen's approach change how we measure poverty?

Empirically, there is an emerging agreement that economic growth does not necessarily lead to an improvement in welfare (Bourguignon et al., 2010; Ahluwalia, 2011) and that monetary poverty measurement is not a sufficient proxy for poverty in all its dimensions (Ravallion, 2011b). A key motivation for this theoretical framework is that the traditional Chinese concept of poverty is multidimensional.

1 Source: Director Xiaojian Fan's report for the State Council Leading Group Office of Poverty Alleviation and Development [in Chinese].

2 Appendix A provides the poverty results in China. For related studies see: Ravallion and Jalan (1999), Chen and Ravallion (2004), Chen and Ravallion (2008), and UNDP (2013).

3 Yao (2000); 林伯强 (2003) [in Chinese]; 王祖祥, 范传强, and 何耀 (2006) [in Chinese], 万广华 and 张茵 (2006) [in

Chinese], Ravallion (2011a), Montalvo and Ravallion (2010), 沈扬扬 (2012a, 2012b) [in Chinese]) studied the

relationship of economic growth and income inequality to poverty and, in general, concluded that economic growth reduces poverty, but inequality increases poverty.

4 See Rozelle (1998), Park, Wang, and Wu (2002), Chen, Ravallion, Galasso, Piazza, and Tidrick (2005), Meng (2013), and $\mathrm{Li}$ and Sicular (2014).

5 See Ravallion and Jalan, 2000), Jalan and Ravallion, 2002), Brown and Park, 2002), Ravallion and Chen, 2007), 万广 华 and 张藕香, 2008) [in Chinese], 罗楚亮, 2010) [in Chinese]. 
'Poverty' in Chinese can be written as 贫困', which combines two characters that can be divided into 'pin' and 'kun' with different meanings. 'Pin' means 'deficient', while 'kun' means 'being trapped' and hence unable to access development-related resources. ${ }^{6}$ This concept has shaped China's anti-poverty policies since the 1980s. For example, the recent document 'Outline of China's Rural Poverty Alleviation of 2011-2020' takes a multidimensional view and articulates the general target of anti-poverty policies as removing two worries - those related to food and clothing - and providing 'three guarantees' - for basic health care, housing, and access to compulsory education. China is thus a pioneer in conceptualizing and implementing multidimensional poverty alleviation policies. But China has not yet officially applied multidimensional methods of poverty measurement. This paper creates and analyzes China's global MPI to explore what value-added an MPI for China might have.

\subsection{Literature Review}

This paper is not the first study of multidimensional poverty in China. Multiple poverty concepts emerged in the 1990s with dashboards of indicators. For instance, 吴国宝 (1997) used indicators of education, assets, caloric intake, clean drinking water, housing, health condition, time use, and health to explore the characteristics of poor people. 李小云 et al. (2005) designed a participatory multidimensional poverty index with eight dimensions, including production, living standard, and education. During the beginning of the 21 st century, multidimensional poverty concepts from outside of China were introduced. ${ }^{7}$ The pioneering empirical study using the Alkire Foster (AF) method is 王小林 and Alkire (2009). They found that nearly $20 \%$ of the households in both rural and urban China were experiencing deprivations in at least three out of eight non-income dimensions. Since then, many studies have applied the AF method for empirical analyses. For instance, 邹薇 and 方迎风 (2011), 蒋翠侠 et al. (2011) and 张全红 (2015) analyze dynamic changes in poverty; 方迎风 (2012) compares the TFR and AF method; 蒋翠侠 et al. (2011) and 张 全红 (2015) explore general weighting structures. Wang (2016) explores the relationship between income and multidimensional poverty. But none of the existing papers use nationally representative datasets, making it impossible for the existing academic literature to state how multidimensional poverty has evolved in China.

In contrast with the existing papers, our results use nationally representative data. Additionally, the MPI we compute is internationally comparable and can be compared across three time periods. Moreover, this paper explores poverty by regions, social characteristics, and indicators, and investigates the relationship between monetary and multidimensional poverty. It provides the first definitive national picture of poverty and how it changes over time according to the global MPI.

While we are very pleased to offer this new study and grateful for the CFPS dataset that makes it possible, we would like to acknowledge two shortcomings at the outset. The first is that the global

\footnotetext{
${ }^{6}$ See X. Wang, Feng, Xia, and Alkire (2016).

${ }^{7}$ For instance, the Watts multidimensional poverty index (陈立中, 2008a, 2008b); the fuzzy sets method (候卉, 王娜, and 王丹青, 2012) and (方迎风, 2012); principle factor and cluster analysis (叶初升 and 赵锐, 2012); Rasch model (范 晨辉, 薛东前, and 马蓓蓓, 2015), etc. For others, see 尚卫平 and 姚智谋 (2005) [in Chinese], 洪兴建 (2005) [in Chinese], 叶普万 $(2005,2006)$ [in Chinese], 张建华 and 陈立中 (2006) [in Chinese], 陈立中 (2008a) [in Chinese], 叶 初升 and 王红霞 (2010) [in Chinese], 刘泽琴 (2012) [in Chinese], 邹薇 and 方迎风 (2012) [in Chinese], and 丁建军 (2014).
} 
MPI, while very useful as a tool to compare China to other countries across the developing world, is actually inappropriate for contemporary China because it reflects the degree of 'acute' poverty, which has largely been resolved in China. So for the purposes of national policy, China would probably wish to build an improved national MPI. Second, despite the great benefits of the CFPS dataset, its sample size is relatively small compared to China's population. This results in estimations with high standard errors and does not permit all relevant disaggregated comparisons, for example by each province or county. Estimations should also be run on larger datasets in order to obtain high-resolution poverty maps.

The paper unfolds as follows: we present the methodology, data and indicators in the second and third sections respectively. Section four presents China's national poverty results from 2010 to 2014. Detailed disaggregated analyses are shared in section five. The relationship between monetary and multidimensional poverty is explored in section six; robustness tests for weights are shared in section seven, then the paper concludes.

\section{Methodology}

We use the AF methodology proposed by (Alkire and Foster, 2011) due to its intuitive and policyrelevant properties (Alkire et al., 2015).

\subsection{Adjusted Headcount Ratio}

Suppose there are $n$ people in China and their well-being is evaluated by $d$ indicators. We denote each person $i$ 's achievement in each indicator $j$ by $x_{i j} \in \mathbb{R}$ for all $i=1, \ldots, n$ and $j=1, \ldots, d$. Matrix $X$ with a size of $n \times d$ contains the achievements of $n$ persons in $d$ indicators. The rows denote persons and columns denote indicators.

The AF method is based on a counting approach. It identifies who is poor using two kinds of cutoffs: a deprivation cutoff for each indicator and a single cross-dimensional poverty cutoff. We denote the deprivation cutoff for indicator $j$ by $z_{j}$ in vector $z$. If any person $i$ 's achievement in any indicator $j$ falls below the deprivation cutoff - that is, if $x_{i j}<z_{j}$ - then the person is deprived in that indicator. Otherwise they are non-deprived. Then, a deprivation status score $g_{i j}$ is assigned to denote each person's deprivation status in each indicator based on $Z_{j}$. In this case, person $i$ is deprived in indicator $j, g_{i j}=1$; if non-deprived, $g_{i j}=0$. The deprivation cutoffs for China's global MPI are presented in section 3 .

Each indicator is assigned a weight based on the value of that deprivation relative to other indicator deprivations. Thus, a weighting vector $w$ is used to weight each indicator $j$. We denote each indicator's weight as $w_{j}$, such that $w_{j}>0$ and $\sum_{j=1}^{d} w_{j}=1$. Next, an overall deprivation score $c_{i} \in$ $[0,1]$ of each person $i$ is computed by summing the deprivation status of all $d$ indicators, each multiplied by the corresponding weights $w_{j}$, such that $c_{i}=\sum_{j=1}^{d} w_{j} g_{i j}$. The deprivation scores of all $n$ persons are summarized by vector $c$. The global MPI gives equal weights to each dimension and equal weights for each indicator within dimension. China's weights follow this structure, as outlined in section 3 .

A person is identified as multidimensionally poor if their deprivation score is greater than or equal to the value of the poverty cutoff $k$. Thus the $i^{\text {th }}$ person is poor if $c_{i} \geq k$, where $k \in(0,1]$, and non- 
poor if $c_{i}<k$. The case in which $k=1$ is called the intersection approach, where a person must experience all deprivations to be identified as poor. When $0<k \leq \min _{j}\left\{w_{1}, \ldots, w_{d}\right\}$, it is referred to as the union approach, where even one deprivation identifies each person as poor. For $\min _{j}\left\{w_{1}, \ldots, w_{d}\right\}<k<1$, it is referred to as the intermediate approach. Clearly, the appraisal of poverty is sensitive to cutoff $k$. The global MPI uses a poverty cutoff $k$ of one-third or $33.33 \%$, and so this is the value we apply.

Having identified the set of $q$ poor persons and their deprivation scores, we obtain the MPI, which is also called the adjusted headcount ratio or $M_{0}$. Applying the focus axioms, ${ }^{8}$ we obtain the censored deprivation score vector $c(k)$ from vector $c$, such that $c_{i}(k)=c_{i}$ if $c_{i} \geq k$ and $c_{i}(k)=0$ if $c_{i}<k$. In other words, we only consider the deprivations of persons who have been identified as poor, following Sen 1976. The MPI (or adjusted headcount ratio $M_{0}$ ) is equal to the average of the censored deprivation scores:

$M P I=M_{0}=\frac{1}{n} \sum_{j=1}^{d} c_{i}(k)$

\subsection{Properties of MPI}

As mentioned, the MPI or $M_{0}$ has good properties for analysis with strong policy implications. First, the MPI can reflect the incidence and intensity of multidimensional poverty, as it can be expressed as a product of two components:

$M P I=M_{0}=\frac{q}{n} \times \frac{1}{q} \sum_{j=1}^{d} c_{i}(k)=H \times A$,

where $q$ is the number of poor, $H$ is the share of the population who are multidimensionally poor or the headcount ratio (incidence), and $A$ is the average proportion of deprivations in which the poor are deprived (intensity). We can see transparently that either a decrease in $H$ or $A$ could reduce $M_{0}$. In this sense, $H$ and $A$ give us more information on how poverty changed: if $M_{0}$ was reduced when only $H$ decreased, then poor people exited poverty - although if $A$ increases it is likely that mainly the marginally poor left poverty. On the other hand, if a reduction in $M_{0}$ occurs by reducing the deprivation of the poorest of the poor, then $A$ certainly decreases, but $H$ might or might not change. ${ }^{9}$

Another property that is vital to policy and to the United Nations Sustainable Development Goals is disaggregation. If the entire population is divided into $g$ mutually exclusive and collectively exhaustive groups, then the overall $M_{0}$ can be expressed as a weighted average of the $M_{0}$ values of $g$ subgroups, where the weights are the respective population shares. Let the subscript $l=1, \ldots, g$

\footnotetext{
${ }^{8}$ In the multidimensional context, two types of focus axioms are needed: one relates to deprivations and says that any increase in non-deprived achievements should not affect poverty measurement, and the other relates to non-poor persons and says that any increase in the achievement of non-poor persons should not affect poverty results. See Bourguignon (2003) and Alkire and Foster (2011).

${ }^{9}$ Apablaza and Yalonetzky (2013) show the change in $M_{0}$ can be expressed as $\Delta M_{0}=\Delta H+\Delta A+\Delta M \times \Delta A$.
} 
denote the particular subpopulation with $\sum_{l=1}^{g} n_{l}=n$, the population share is $\frac{n_{l}}{n}, n_{l}$ is the subgroup population, and $M_{0}\left(n_{l}\right)$ denotes the subgroups' adjusted headcount ratio or MPI. Formally, $M_{0}$ can be expressed as

$M P I=M_{0}=\sum_{l=1}^{g} \frac{n_{l}}{n} M_{0}\left(n_{l}\right)$

This feature is called subgroup decomposability. It helps us understand each group's poverty level and the contribution of different subgroups to the overall level of poverty.

Third, the adjusted headcount ratio can also be broken down to show the contribution of each indicator to overall poverty (dimensional breakdown). The statistic of the censored headcount ratio is tremendously useful for tracking changes over time. The censored headcount ratio is the proportion of the population that is multidimensionally poor and simultaneously deprived in that particular indicator. We denote the censored headcount ratio of indicator $j$ by $h_{j}$. The MPI or $M_{0}$ can be expressed as the weighted sum of the censored headcount ratios of each of the component indicators:

$M P I=M_{0}=\sum_{j=1}^{d} w_{j} h_{j}=\sum_{j=1}^{d} w_{j}\left[\frac{1}{n} \sum_{i=1}^{n} g_{i j}(k)\right]$

Because of $M_{0}$ 's weighting structure, the statistic of 'percentage contribution' allows us to assess the dimensional deprivations that contribute the most to poverty for any given group or overall poverty. We denote the weighted contribution of indicator $j$ to $M_{0}$ by $\phi_{j}$. Then, the percentage contribution of indicator $j$ to $M_{0}$ is

$\phi_{j}=w_{j} \frac{h_{j}}{M_{0}}$.

\section{Data and Indicators}

\subsection{Data}

To estimate China's global MPI, we use the CFPS, which was conducted by the Institute of Social Science Survey (ISSS) at Peking University. The CFPS is a national longitudinal general social survey project that began in 2010 and which aims to elucidate economic and non-economic well-being aspects of the Chinese people. It has now had three waves: 2010, 2012, and 2014. This paper will present the results for all three waves. The survey is drawn from 25 provinces/cities/autonomous regions in Mainland China (excluding Xinjiang, Qinghai, Inner Mongolia, Ningxia, Tibet, and Hainan, Hong Kong, Macao, and Taiwan), ${ }^{10}$ and the weighted samples are designed to be nationally representative. ${ }^{11}$ Each year's sample contains, on average, over 40,000 eligible individuals in over 13,000 households. This paper uses the newest version of CFPS-2010; version 6.0 of the CFPS-2012

\footnotetext{
10 Tibet, Qinghai, Xinjiang, Ningxia, Inner Mongolia, and Hainan were excluded from the sample to reduce costs, but together they make up only $5 \%$ of the population (Xie, 2012, p. 14).

11 According to Xie et al. (2012), 'CFPS chooses 25 provinces which include $94.5 \%$ of the population in Mainland China... could be considered to be national representative'. The Manual of CFPS-2010 states that 'After weighting, the complete national sample represents the national population'.
} 
dataset, and the newest version of CFPS-2014, published in June 2016. The eligible sample size for multidimensional poverty calculation in this paper is 40,844, 43,532, and 44,230 persons in 2010, 2012, and 2014, respectively.

\section{Sample design}

CFPS uses a complex multistage, implicit stratification and probability sampling procedure for survey design. The sampling procedure has three stages. First, primary sampling units (PSU) are selected at the administrative districts/counties level. Next, second-stage sampling units (SSU) are drawn at the administrative villages/neighborhood/=community level. Finally, the third-stage (ultimate) sampling units (TSU) are selected at the household level. Following (Ren and Treiman, 2013), we specified the village/neighborhood as the cluster variable. In terms of the sample representativeness, six strata were initially specified. Five 'large provinces' (including Gansu, Guangdong, Henan, Liaoning, and a provincial-level city of Shanghai) were treated as separate strata; each of these subsamples is provincially representative. The sixth stratum consists of the remaining half of the households (drawn from the remaining 20 provinces sampled) without provincial representativeness. Taking all six strata together, the whole dataset creates the nationally representative sample.

\section{Sampling weights}

In 2012 and 2014, CFPS divided household members into two types. 'Gene members' are those who were included in the initial 2010 wave. Their next generation (e.g. newborn babies, adopted children) are also considered to be gene members. 'Core members' are those who were not included in the initial year of 2010 but are living together with the gene members and have marriage or blood connections to the gene members in the subsequent years. Once they no longer live with the gene members, the core members will no longer be tracked. CFPS does not apply weights for core members, ${ }^{12}$ but obviously they are important household members who affect household-level poverty. In order to take the core members into account, we constructed new individual weights ${ }^{13}$ for them.

\subsection{Global MPI Indicators for China}

The indicators we are using are defined in Table 3-1. There are two main differences compared to the standard global MPI (Alkire and Robles 2016). First, China's MPI estimations draw on nine out of the ten global MPI indicators because data on flooring is not available. Second, we have to change the indicator definition for certain indicators, as described below.

\footnotetext{
${ }^{12}$ For more details see 谢宇 et al. (2014) in chapter 9 'Weight' [in Chinese].

13 We are grateful to Cecilia Calderon from UNDP for helping us construct the individual weight for the core members. We used the gene members' weights as well as the rural/urban, province, age, and gender information. For instance, in 2012, we obtain a population of 1.2 billion by only adding the gene members' weights, which is less than the total population of 1.35 billion. After the re-weighting that considers all eligible members, we have a result of 1.31 billion people, which is a better approximation although still not perfect.
} 
Table 3-1 Dimensions, Indicators, Deprivation Thresholds and Weights

\begin{tabular}{|c|c|c|}
\hline Dimension & Indicator & $\begin{array}{l}\text { Relative } \\
\text { Weight }\end{array}$ \\
\hline \multirow[b]{2}{*}{ Education } & Years of Schooling & $\begin{array}{l}\text { No school-going household member has completed five years of } 1 / 6 \\
\text { schooling and no member has completed primary school. }\end{array}$ \\
\hline & $\begin{array}{l}\text { Child School } \\
\text { Attendance }\end{array}$ & $\begin{array}{l}\text { Any child aged } 7-15 \text { is not attending school up until the age at } 1 / 6 \\
\text { which they would complete class } 8 .\end{array}$ \\
\hline \multirow{2}{*}{ Health } & Child Mortality & Any child has died in the family. \\
\hline & Nutrition & Any person under 70 years of age is malnourished. \\
\hline \multirow{5}{*}{$\begin{array}{l}\text { Living } \\
\text { Standard }\end{array}$} & Electricity & The household has no electricity. \\
\hline & Improved Sanitation & $\begin{array}{l}\text { The household does not have a private toilet, whether indoor or } 1 / 15 \\
\text { outdoor, flush, or non-flush. }\end{array}$ \\
\hline & $\begin{array}{l}\text { Improved Drinking } \\
\text { Water }\end{array}$ & $\begin{array}{l}\text { The household does not have access to improved drinking water, } \\
\text { defined as well/spring water, tap water, or mineral/purified/filtered 1/15 } \\
\text { water. }\end{array}$ \\
\hline & Cooking Fuel & The household cooks with dung, wood, or charcoal. \\
\hline & Assets Ownership* & $\begin{array}{l}\text { The household does not own more than one of the following: TV, } \\
\text { mobile telephone, bike (motorized), motorbike, or refrigerator, and 1/15 } \\
\text { does not own a car or similar vehicle. }\end{array}$ \\
\hline
\end{tabular}

*Note: In 2010, the dataset has no data on refrigerators or similar appliances.

\section{A. Education}

Years of schooling: As in the global MPI, this indicator considers people who are aged 10 years and above to be eligible. The entire household is considered deprived if no household member has completed five years of education. ${ }^{14}$

Child school attendance: As in the global MPI, the entire household is considered deprived if any school-aged child is not attending school up to the age at which they would complete class 8 . For China, the difficulty is determining the starting age of primary school. According to the Compulsory Education Law of People's Republic of China, 'for any child who has reached the age of 6, his/her parents or other statutory guardians shall have him/her enrolled in school to finish compulsory education'. But the law also says 'for children in those areas where the conditions are not satisfied, the initial time of schooling may be postponed to 7 years old'. Meanwhile, authoritative information

\footnotetext{
${ }^{14}$ If all household members reported their education as less than five years or gave a missing value, we use a further constraint and only consider eligible those households in which at least two-thirds of members' information is not missing.
} 
from UNESCO ${ }^{15}$ suggests China's compulsory schooling age is 7. Based on these materials, either 6 or 7 could be the possible starting age. Empirically, only $27 \%$ of six-year-old children were attending primary school in 2012, while $75 \%$ of children were attending primary school at the age of 7 . We thus set seven years as the primary school starting age and set the schooling age range as $7-15$. In locations where 6-year-olds should already have been in school, this may underestimate poverty.

\section{B. Health}

Child mortality: According to the global MPI, if any child has died in the household within the last five years, the household is considered to be deprived. However, CFPS only asks 'if any of your child/children died in your family' and does not provide information on the date of the death. A similar issue happens in some of the MICS surveys. As in those cases, we include all child deaths that are reported by women under 49 years of age and men under 59 years of age.

Nutrition: As in the global MPI, we consider the whole household as deprived if at least one eligible member is malnourished. ${ }^{16}$ However, there are two noteworthy considerations that must be borne in mind when interpreting CFPS nutrition results. First, usually, scales and a ruler are needed in order to collect accurate anthropometric weight and height information. However, CFPS only used the recall process to collect the information. Such self-reported nutrition results are likely to have higher non-sampling measurement errors. Second, we only take into account persons younger than 70 years old. The global MPI ordinarily only considers women under 49 and men under 59 years of age, but the CFPS dataset has nutrition information available for all age cohorts. We restrict consideration to those under 70 years of age because of concerns that the 18.5 BMI standard may not accurately capture the nutrition status for older people due to a decline in bone density in this life cycle period. ${ }^{17}$

\section{Living Standard}

Electricity: Electricity options in CFPS's questionnaires are as follows: 1) no electricity, 2) frequent power outage, 3) occasional power outage, 4) almost no power outage at all. If the household chooses the first option, the household is considered to be deprived.

Improved sanitation: Toilet classification in CFPS is different from in the Millennium Development Goals. ${ }^{18}$ The categories in the CFPS questionnaire are as follows: 1) indoor flush toilet, 2) outdoor

\footnotetext{
${ }^{15}$ See http://stats.uis.unesco.org/unesco/TableViewer/tableView.aspx?ReportId=163.

${ }_{16}$ More specifically, we use 'igrowup' underweight for children aged 0-60 months, 'WHO 2007' BMI-for-age and sex for adolescents aged 61-179 months, and BMI for 15-69 years old. The methodologies follow the World Health Organization (WHO).

${ }^{17}$ In Appendix C, we present malnutrition data (using 18.5 BMI as standard) for different age groups as a robustness test. We can clearly find that among 15-19 year olds and those above 70 years old, the proportions of malnutrition are higher. For the adolescent group, WHO has developed a specific nutrition calculation method, but for older group there is no specific method for now. We exclude those 70 and older because a low BMI could reflect the decrease in bone density that affects this age bracket, as well as their nutritional status.

${ }_{18}$ Members of the household are considered deprived if the household's sanitation facility is not improved according to MDG guidelines or if it is improved but shared with another household. Following the definition of the MDG indicators, 'a household is considered to have access to improved sanitation if it uses: flush or pour flush to piped sewer system; septic tank or pit, latrine; pit latrine with slab; composting toilet; ventilated improved pit latrine. And the excreta
} 
private flush toilet, 3) outdoor public flush toilet, 4) indoor non-flush toilet, 5) outdoor private nonflush toilet, 6) outdoor public non-flush toilet, and 7) other. The classification 'non-flush' toilets (options 4 and 5) is too broad to distinguish some adequate toilets such as protected pit latrines from inadequate toilets. According to statistical results in the 2013 Health Yearbook of China, the prevalence of adequate toilets in rural China was $72 \%$ at the end of 2012. If, using the CFPS-2012 data, we sum options $1,2,4$, and 5 , we get a slightly larger number of $88 \% .{ }^{19}$ This suggests that $1,2,4$, and 5 should be considered as non-deprived; other options are considered deprived. We recognize that this may underestimate deprivation in sanitation, but it appears to provide the best match possible to official figures using this dataset.

Improved drinking water. Following the MDG guidelines for drinking water, we consider categories in CFPS of 'tap water', 'mineral/purified/filtered water', and 'rainwater' as non-deprived; and we consider 'river/lake water', 'well/spring water', 'cellar water', 'pond water', and 'others' as deprived. The difficult identification category is 'well/spring water', because the MDG categories clearly define protected well/spring water as non-deprived, whereas unprotected sources are deprived. However, CFPS does not distinguish between them. Thus, taking into account the Chinese government's commitment in 2012 to 'arrange a 22 billion RMB budget to make sure 8 million rural students and teachers can drink safe drinking water; make sure the prevalence for rural resident's safety drinking water [is] up to $81 \%{ }^{20}$ and considering that the ratio of 'tapped water' $(60 \%)$ and 'well/spring water' $(35 \%)$ added up to a significantly higher number of $95 \%$, we consider 'well/spring' to be nonsafe/unprotected and identify it as deprived. Of course, this has the risk of overestimating water deprivation from protected springs. We did not take into account the distance to reach water because CFPS does not include the relevant information.

Flooring: CFPS does not collect flooring information. We drop this indicator and re-weight the other five indicators from $1 / 18$ to $1 / 15$ within the 'living standard' dimension.

Cooking fuel: According to the MDGs, we consider households to be deprived if they cook with firewood/straw, coal, and 'other', and consider households using gas/liquid/natural gas, methane, and electricity to be non-deprived.

Assets ownership: We consider a household that does not own more than one of the following assets to be deprived: TV, mobile telephone, bike (motorized), motorbike, or refrigerator. If they own a car or similar vehicle, they are not deprived in assets. Compared to the global MPI, the assets indicator does not include a radio or landline telephone, and motorized bicycle is used instead of bicycle. In addition, there is no information for refrigerators and similar appliances in CFPS-2010 data, so we only consider the remaining assets.

disposal system is considered improved if it is private or shared by a reasonable number of households'. Source: The Challenge of Slums: Global Report on Human Settlements 2003 (Revised version, April 2010).

19 According to the China Health Statistics Yearbook 2013, the definition of 'sanitation toilet' in the yearbook is 'have walls around the toilet, have a roof, the toilet pit and septic tank do not leak, clean inside the toilet, no maggots, basically not smelly. The septic tank is closed and covered, the feces/dejects/excrement and urine/night soil/ordure pellet can be cleaned up in time with harmless treatment'. This means 'sanitation toilet' belongs to the type of pit latrine with slab, composting toilet, or ventilated improved pit latrine groups. Most of the non-flush toilets belong to the improved sets according to MDG goals.

${ }^{20}$ http://www.eeo.com.cn/2012/0607/227786.shtml [in Chinese in 2012-June]. 


\section{Advantages and limitations of the dataset}

The CFPS is a high-quality nationally representative survey with sufficient information to compute a global MPI for China and to undertake basic decomposition and disaggregation. The limitation, as mentioned above, is that, due to the sample size being relatively small, we are not able to decompose by all provinces but only by five provinces, and we also obtain relatively high standard errors. In terms of the indicators for the global MPI, no flooring variable is available, so we drop that indicator. Furthermore, nutrition is self-reported rather than anthropometric, which will increase non-sampling measurement errors. It also is available for a much larger age range than in other global MPI datasets, which affects cross-national comparisons. Other indicators have some differences from the global MPI computed in other countries' datasets as mentioned and justified above. Despite these issues, the CFPS dataset opens a new and significant window to undertake the first definitive nationally representative study of the reduction of multidimensional poverty in China, and that is the aim of this paper.

\section{China's Global MPI}

\subsection{Basic Results}

In general, we found that China's multidimensional poverty is not high according to the global MPI standard. Furthermore, poverty has decreased significantly over time. China's global MPI had the value of 0.035 in 2010. Its MPI decreased to 0.023 in 2012 and to 0.017 in 2014 . From 2010 to 2012 there is an absolute annualized change of 0.006 , which is statistically significant at $\alpha=0.05$. From 2010 to 2014 , the absolute annualized change is 0.05 with statistical significance at $\alpha=0.05{ }^{21}$ The headcount ratio $(\mathrm{H})$ fell from $8.2 \%$ in 2010 to $4.0 \%$ in 2014, and the change is statistically significant. Though the incidence of multidimensional poverty in China is not high, acute multidimensional poverty still affected more than 70 million people in $20 \mathrm{xx}$. The intensity (A) showing the average weighted deprivations among the poor was $42.4 \%$ in $2010,43.0 \%$ in 2012 , and $41.3 \%$ in 2014 , respectively, but the annualized changes are not statistically significant (Table 4-1). In general, the intensity means, on average, China's MPI poor people are deprived in roughly one health indicator, one education indicator, and one or two living standard indicators.

Following the full analyses of the global MPI, we explore two subsets of the MPI poor - those who experience 'severe poverty' and those living in 'destitution'. The first can be defined as those who are deprived in $50 \%$ or more of indicators $(\mathrm{k}=50 \%$ ). In 2010 , around $1.3 \%$ of the population was severely poor; this number decreases significantly to $0.3 \%$ in 2014 . We also calculated levels of 'destitution'. OPHI's destitution measure uses different deprivation thresholds for eight indicators, and we identify those who are deprived in at least one third of these extreme indicators to be destitute (see Appendix C). ${ }^{22}$ Rates of destitution are low: by 2014, destitution affected only about $0.4 \%$ of the population.

\footnotetext{
${ }^{21}$ For the MPI's annualized change results and the relative statistically significance test, please see Appendix F. Although the confidence intervals overlap the significance test for changes over time is satisfied as stated above. See Alkire et al., Chapter 9 (2015).

22 Also see: Seth (2014) and Alkire (2016).
} 
Table 4-1 China's National MPI Results: 2010, 2012, and 2014

\begin{tabular}{|c|c|c|c|c|c|c|}
\hline & M0 & Confidence Interval (95\%) & $\begin{array}{l}\mathrm{H} \\
(\%)\end{array}$ & $\begin{array}{l}\text { Confidence Interval } \\
(95 \%)\end{array}$ & $\begin{array}{l}\mathrm{A} \\
(\%)\end{array}$ & $\begin{array}{l}\text { Confidence Interval } \\
(95 \%)\end{array}$ \\
\hline \multicolumn{7}{|l|}{2010} \\
\hline MPI & 0.035 & {$[0.027,0.042]$} & 8.2 & {$[6.7,9.7]$} & 42.4 & {$[41.3,43.5]$} \\
\hline Severity & 0.007 & {$[0.004,0.011]$} & 1.3 & {$[0.8,1.9]$} & 57.2 & {$[56.0,58.4]$} \\
\hline Destitution & 0.003 & {$[0.002,0.004]$} & 0.7 & {$[0.4,1.0]$} & 41.6 & {$[40.1,43.1]$} \\
\hline \multicolumn{7}{|l|}{2012} \\
\hline MPI & 0.023 & {$[0.016,0.030]$} & 5.4 & {$[4.1,6.8]$} & 43.0 & {$[40.2,45.8]$} \\
\hline Severity & 0.006 & {$[0.001,0.011]$} & 1.0 & {$[0.1,1.8]$} & 58.8 & {$[56.6,61.0]$} \\
\hline Destitution & 0.055 & {$[0.002,0.009]$} & 1.3 & {$[0.6,2.0]$} & 42.0 & {$[39.0,45.1]$} \\
\hline \multicolumn{7}{|l|}{2014} \\
\hline MPI & 0.017 & {$[0.013,0.020]$} & 4.0 & {$[3.2,4.9]$} & 41.3 & {$[40.1,42.5]$} \\
\hline Severity & 0.569 & {$[0.544,0.594]$} & 0.3 & {$[0.1,0.5]$} & 56.9 & {$[54.4,59.4]$} \\
\hline Destitution & 0.409 & {$[0.380,0.437]$} & 0.4 & {$[0.2,0.6]$} & 40.9 & {$[38.0,43.7]$} \\
\hline
\end{tabular}

- Change is significant by $95 \%$

Notes: 1. YS is 'years of schooling', SA is 'school attendance', CM is 'child mortality', $\mathrm{N}$ is 'nutrition', $\mathrm{E}$ is 'electricity', $\mathrm{S}$ is 'sanitation', $\mathrm{W}$ is 'water', $\mathrm{CF}$ is 'cooking fuel' and $\mathrm{A}$ is 'assets'. 2. The square brackets are results at a 95\% confidence interval. Source: CFPS dataset.

\section{Figure 4-1 Multidimensional Poverty Headcount Ratios $(H)$}

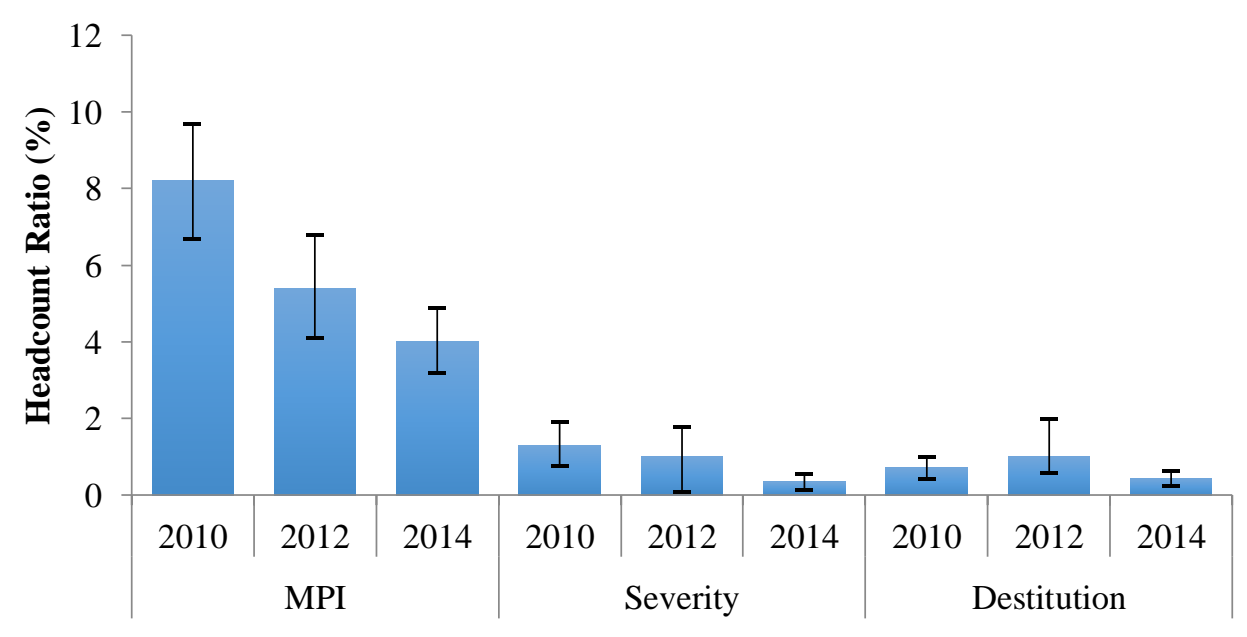




\subsection{Composition of the MPI: Indicator Analysis}

Figure 4-2 shows the raw headcount ratio (RHR) and censored headcount ratio (CHR), respectively. The RHR is the percentage of the population who are deprived in each indicator. The CHR shows the percentage of the population who are poor and at the same time are deprived in each indicator. In terms of the RHR, cooking fuel and safe drinking water have the highest levels of deprivation in each year, followed by 'nutrition' and 'sanitation'. However, the CHR shows that, besides the indicators just mentioned, the poor are also likely to be deprived in 'years of schooling. ${ }^{23}$ China is unusual in having very striking differences between its raw and censored headcount ratios for nutrition. This may be partly explained by the data issues mentioned above.

According to changes in incidence over time, from 2010 to 2014, there are statistically significant annualized decreases of 0.8 percentage points in the censored headcount ratio for years of schooling, 0.6 for nutrition, 1.9 for sanitation, 2.6 for water, and 1.6 for cooking fuel, implying improvements in those indicators. ${ }^{24}$ There is no significant change in the levels of school attendance, child mortality, and electricity, partly because the censored headcount ratios of these indicators are very low already.

\section{Figure 4-2 Raw and Censored Headcount Ratios of People Deprived in Each Indicator}

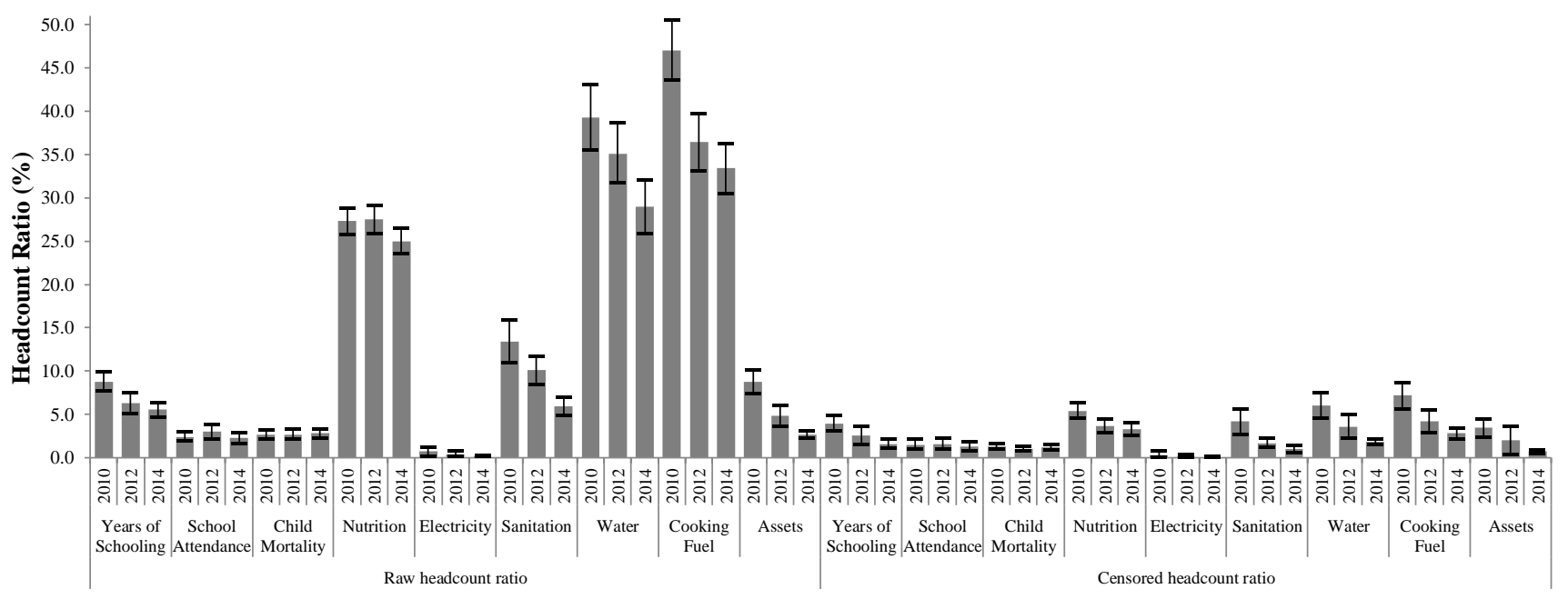

Figure 4-3 shows indicators' percentage contribution (PCB) to MPI. Because indicators are not equally weighted, it is different from the incidence result. The PCB suggests that nutrition contributes the most to MPI in 2014 (more than in previous years given the decline in poverty), followed by years of schooling, school attendance, safe drinking water, and cooking fuel. Electricity contributes only $1 \%$ to MPI, which reflects the reality of the electricity grid infrastructure in China. According to the changes, deprivations in nutrition, school attendance, and child mortality are decreasing more slowly than MPI, hence their percentage contribution is increasing. The conclusions

\footnotetext{
23 This also reflects unbalanced development in China from a unidimensional point of view, and those indicators should be considered even if they are not affecting all multidimensionally poor people.

${ }^{24}$ MPI's annualized change results and the relevant statistically significance tests, please see Appendix F.
} 
suggest anti-poverty policies should increase their emphasis on such deprivations and sustain support for adult life-long learning as well as for water and cooking fuel in the living standard dimension.

\section{Figure 4-3 Percentage Contribution of Each Indicator to MPI}

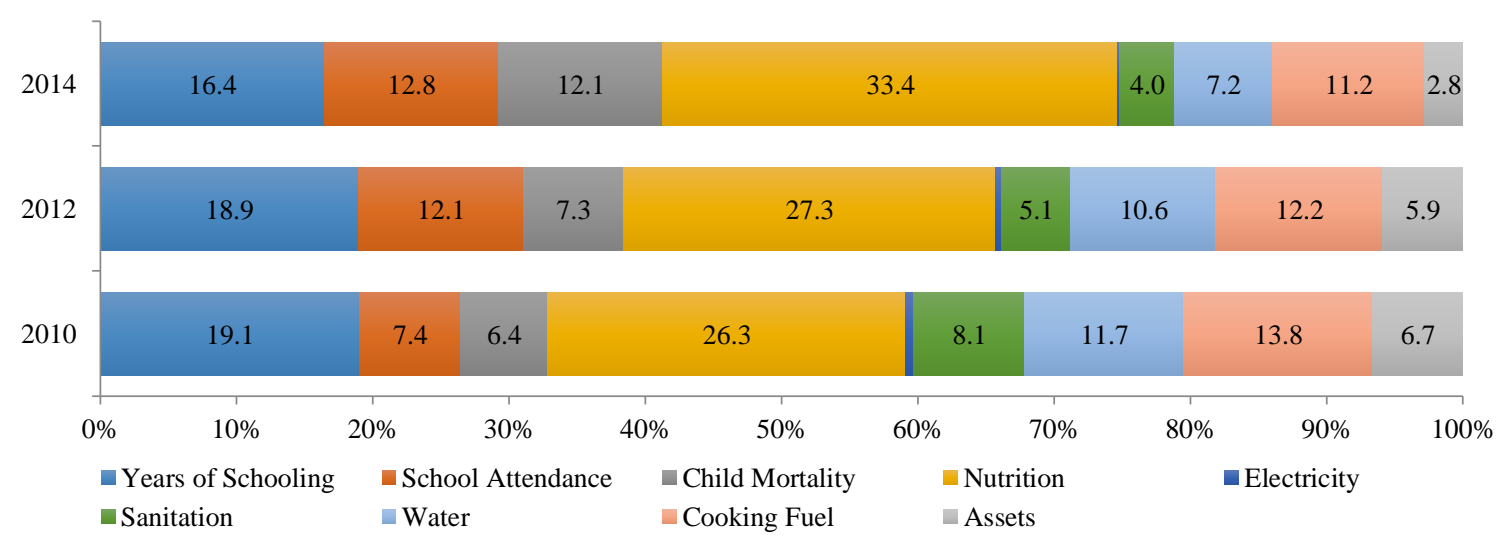

\section{Disaggregated Analysis of MPI}

\subsection{MPI in Geographic Areas}

Rural and Urban: ${ }^{25}$ As rural poverty exceeds urban poverty in many countries, we expect rural residents to be poorer. The results tell the same story (Table 5-1): People who are living in rural areas are more likely to be poor compared to people who are living in urban areas. For instance, in $2010,12.6 \%$ of the population in rural areas were MPI poor, while the headcount ratio was only $3.5 \%$ in urban areas. The intensity (A) in rural areas was also higher than in urban areas. Considering the $\mathrm{CHR}$, the incidence of deprivation in all indicators in urban areas is lower than in rural areas. In rural areas, cooking fuel, safe drinking water, and nutrition have the highest deprivation rates. ${ }^{26}$

In terms of changes, poverty is decreasing in both areas over time. The MPI in rural areas decreased from 0.054 in 2010 to 0.028 in 2014 , which is statistically significant; the headcount ratio decreased from $12.6 \%$ to $6.7 \%$ during the same period. Meanwhile, the MPI in urban areas decreased from 0.014 in 2010 to 0.007 in 2014.

\footnotetext{
25 CFPS-2012 includes four type of variables for distinguishing rural-urban areas: 1) rural-urban division standard defined by the National Bureau of Statistics (NBS) of China; 2) division by the type of village/neighborhood community; 3) rural/urban division by hukou of the household head; and 4) communities type: city, town, village, and suburb. We use the first one.

${ }^{26}$ According to J. Zhang and Smith (2005), 420 thousand people died because of indoor air pollution in China. Another report published by the World Bank (世界银行, Ald, and ASTAE, 2013) mentioned that solid fuel is still the main cooking and heating source in rural China. Since the cost for a clean fuel source is high for rural residents, in the short term, they will not change cooking fuel sources by themselves.
} 


\section{Table 5-1 Poverty in Rural and Urban Areas}

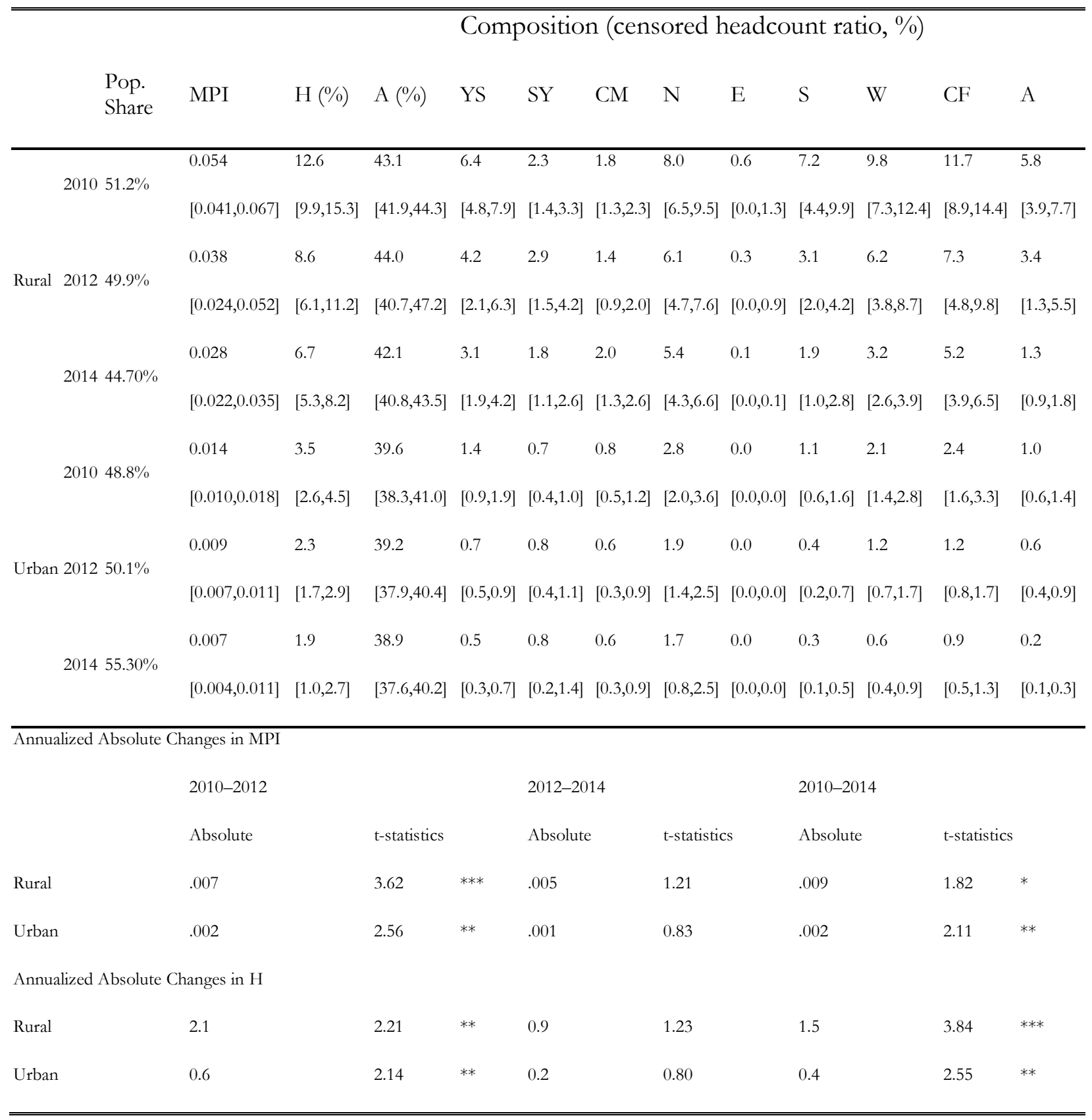

Note: *** statistically significant at $\alpha=0.01,{ }^{* *}$ statistically significant at $\alpha=0.05,{ }^{*}$ statistically significant at $\alpha=0.10$.

Three regions: China's provinces are customarily divided into three major regions: East, Central, and West (NSB of China, 2015). ${ }^{27}$ The East is the most developed region because of its advantage in

${ }_{27}$ Eastern provinces (municipalities) include Beijing, Tianjin, Hebei, Liaoning, Shanghai, Jiangsu, Zhejiang, Fujian, Shandong, and Guangdong; Central provinces include Shanxi, Jilin, Heilongjiang, Anhui, Jiangxi, Henan, Hubei, and Hunan; Western provinces (autonomous regions and municipalities) include Guangxi, Chongqing, Sichuan, Guizhou, Yunnan, Shaanxi, and Gansu (NBS of China, 2015). The definition follows not only the geographic location but also associates with each province's economic development level. 
geographic position and the national development strategy, followed by the Central region. The West is the poorest region, covered by mountains, hills and plateaus that lead to low agriculture production and inconvenient traffic. More than $70 \%$ of rural residents and most ethnic minorities live in the West.

According to our results, the West is significantly poorer than the East or Central regions. In terms of the CHR, we find the West's composition results are similar to rural areas. In the East, cooking fuel and safe drinking water contribute less to MPI, nutrition contributes relatively more. Multidimensional poverty consistently decreases from 2010 to 2014 in all three regions, but the decrease is not statistically significant in the East from 2012 to 2014, nor in the West from 2010 to 2012 and 2012 to 2014; however poverty in the West decreased significantly 2014-2010: from 15.4\% incidence to $8.1 \%$. Years of schooling, nutrition, cooking fuel and water are the indicators that decrease most in each area.

Table 5-2 Poverty in Three Regions

\begin{tabular}{|c|c|c|c|c|c|c|c|c|c|c|c|c|c|}
\hline & & & & & Comp & osition & n (cens & sored h & leadco & ant rati & $10, \%)$ & & \\
\hline & $\begin{array}{l}\text { Pop. } \\
\text { Share }\end{array}$ & MPI & $\mathrm{H}(\%)$ & A $(\%)$ & YS & SY & $\mathrm{CM}$ & $\mathrm{N}$ & $\mathrm{E}$ & S & W & $\mathrm{CF}$ & A \\
\hline \multirow{6}{*}{ East } & \multirow{2}{*}{$201037.2 \%$} & 0.018 & 4.6 & 39.8 & 2.0 & 0.8 & 1.0 & 3.5 & 0.0 & 1.4 & 3.0 & 3.3 & 1.4 \\
\hline & & {$[0.015,0.022]$} & {$[3.7,5.6]$} & {$[38.9,40.7]$} & {$[1.4,2.6]$} & {$[0.6,1.1]$} & {$[0.5,1.5]$} & {$[2.7,4.3]$} & {$[0.0,0.0]$} & {$[0.9,1.9]$} & {$[2.2,3.9]$} & {$[2.4,4.1]$} & {$[0.9,1.9]$} \\
\hline & \multirow{2}{*}{$201239.5 \%$} & 0.011 & 2.8 & 39.1 & 1.1 & 0.8 & 0.5 & 2.3 & 0.0 & 0.7 & 1.6 & 1.8 & 0.8 \\
\hline & & {$[0.008,0.014]$} & {$[2.1,3.5]$} & {$[37.8,40.4]$} & {$[0.7,1.4]$} & {$[0.4,1.2]$} & {$[0.3,0.8]$} & {$[1.6,2.9]$} & {$[0.0,0.0]$} & {$[0.3,1.1]$} & {$[1.0,2.1]$} & {$[1.2,2.4]$} & {$[0.5,1.1]$} \\
\hline & \multirow{2}{*}{$201439.9 \%$} & 0.008 & 1.9 & 40.6 & 0.9 & 0.6 & 0.4 & 1.7 & 0.0 & 0.3 & 1.1 & 1.2 & 0.4 \\
\hline & & {$[0.006,0.010]$} & {$[1.5,2.4]$} & {$[39.4,41.8]$} & {$[0.6,1.1]$} & {$[0.3,0.9]$} & {$[0.2,0.7]$} & {$[1.2,2.1]$} & {$[0.0,0.1]$} & {$[0.1,0.5]$} & {$[0.7,1.5]$} & {$[0.8,1.6]$} & {$[0.2,0.5]$} \\
\hline \multirow{6}{*}{ Centra } & \multirow{2}{*}{$201034.6 \%$} & 0.024 & 6.1 & 40.2 & 2.4 & 0.9 & 1.0 & 4.3 & 0.2 & 2.6 & 5.0 & 5.5 & 2.1 \\
\hline & & {$[0.019,0.030]$} & {$[4.8,7.4]$} & {$[39.4,41.0]$} & {$[1.8,2.9]$} & {$[0.5,1.2]$} & {$[0.6,1.4]$} & {$[3.2,5.3]$} & {$[0.1,0.5]$} & {$[1.6,3.7]$} & {$[3.7,6.3]$} & {$[4.2,6.7]$} & {$[1.6,2.6]$} \\
\hline & \multirow{2}{*}{$201239.5 \%$} & 0.015 & 3.6 & 41.1 & 1.4 & 0.8 & 0.8 & 2.9 & 0.0 & 1.2 & 2.6 & 2.9 & 0.8 \\
\hline & & {$[0.011,0.018]$} & {$[2.7,4.5]$} & {$[40.0,42.3]$} & {$[1.0,1.8]$} & {$[0.4,1.1]$} & {$[0.4,1.2]$} & {$[2.1,3.7]$} & {$[0.0,0.0]$} & {$[0.6,1.8]$} & {$[1.8,3.5]$} & {$[2.1,3.8]$} & {$[0.5,1.2]$} \\
\hline & \multirow{2}{*}{$201433.2 \%$} & 0.013 & 3.2 & 40.5 & 0.9 & 1.0 & 1.0 & 2.8 & 0.0 & 0.6 & 2.0 & 2.3 & 0.5 \\
\hline & & {$[0.010,0.016]$} & {$[2.5,4.0]$} & {$[39.3,41.7]$} & {$[0.5,1.3]$} & {$[0.6,1.4]$} & {$[0.5,1.4]$} & {$[2.1,3.6]$} & {$[0.0,0.1]$} & {$[0.2,0.9]$} & {$[1.3,2.6]$} & {$[1.6,3.0]$} & {$[0.2,0.7]$} \\
\hline \multirow{5}{*}{ West } & & 0.068 & 15.4 & 44.4 & 8.4 & 3.3 & 2.1 & 9.5 & 0.8 & 9.8 & 11.4 & 14.4 & 7.8 \\
\hline & 20 & {$[0.046,0.090]$} & {$[10.8,20.0]$} & {$[43.0,45.8]$} & {$[5.8,11.1]$} & {$[1.6,4.9]$} & {$[1.3,2.9]$} & {$[7.1,11.8]$} & {$[0.0,2.0]$} & {$[5.1,14.6]$} & {$[7.0,15.7]$} & {$[9.7,19.1]$} & {$[4.6,11.1]$} \\
\hline & \multirow[b]{2}{*}{$201226.7 \%$} & 0.052 & 11.6 & 45.1 & 5.8 & 4.6 & 2.0 & 8.0 & 0.6 & 4.0 & 8.1 & 9.4 & 5.2 \\
\hline & & {$[0.028,0.076]$} & {$[7.1,16.1]$} & {$[41.0,49.2]$} & {$[2.0,9.6]$} & {$[2.2,6.9]$} & {$[1.1,2.9]$} & {$[5.6,10.5]$} & {$[0.0,1.6]$} & {$[2.1,5.8]$} & {$[3.7,12.5]$} & {$[4.9,14.0]$} & {$[1.5,9.0]$} \\
\hline & $201426.9 \%$ & 0.034 & 8.1 & 41.9 & 3.7 & 2.7 & 2.6 & 6.4 & 0.1 & 2.7 & 2.6 & 5.8 & 1.5 \\
\hline
\end{tabular}




\begin{tabular}{|c|c|c|c|c|c|c|c|c|c|}
\hline \multicolumn{10}{|c|}{ Annualized Absolute Changes in M0 } \\
\hline & \multicolumn{3}{|l|}{ 2010-2012 } & \multicolumn{3}{|l|}{ 2012-2014 } & \multicolumn{3}{|l|}{$2010-2014$} \\
\hline & Absolute & \multicolumn{2}{|c|}{ t-statistics } & Absolute & \multicolumn{2}{|c|}{ t-statistics } & Absolute & \multicolumn{2}{|c|}{ t-statistics } \\
\hline East & .005 & 3.11 & $* * *$ & .001 & 0.68 & & .003 & 3.81 & $* * *$ \\
\hline Central & .004 & 3.20 & $* * *$ & .002 & 1.86 & $*$ & .003 & 4.94 & *** \\
\hline West & .008 & 0.97 & & .009 & 1.32 & & .007 & 3.62 & *** \\
\hline \multicolumn{10}{|c|}{ Annualized Absolute Changes in $\mathrm{H}$} \\
\hline East & 1.3 & 3.21 & $* * *$ & 0.2 & 0.59 & & 0.7 & 3.85 & *** \\
\hline Central & 0.9 & 3.10 & $* * *$ & 0.4 & 2.11 & $* *$ & .07 & 5.04 & *** \\
\hline West & 1.9 & 1.16 & & 1.7 & 1.31 & & 1.5 & 3.84 & *** \\
\hline
\end{tabular}

\subsection{MPI in Five Provinces}

As mentioned, there are five 'large provinces' (Liaoning, Shanghai, Guangdong, Henan, and Gansu) for which the CFPS data are representative at the provincial level. We use them to provide provincial comparisons.

The results show Gansu to be the poorest province, but its MPI is not significantly higher than the other provinces, except Liaoning and Shanghai. The least poor provinces are Liaoning and Shanghai, followed by Henan and Guangdong. This is quite unexpected because the ranking by GDP per capita for these provinces is rather different, with Shanghai having the highest GDP per capita and Henan and Gansu the lowest. ${ }^{28}$ However, it also reflects that economic growth and income levels do not necessarily lead to poverty reduction. ${ }^{29}$ The ranking by incidence $(\mathrm{H})$ follows the ranking by MPI across provinces.

In terms of composition, while cooking fuel, nutrition, and water are the indicators in which most people are deprived for all provinces, different provinces are facing different problems. For instance, for the poorest province of Gansu, although all indicators have larger CHRs compared to other provinces, cooking fuel, nutrition, safe drinking water, and years of schooling are particularly high. For Guangdong and Shanghai, nutrition has the highest incidence among the poor. Although deprivations in education are common in almost all provinces, Shanghai is an exception. This shows that the composition of multidimensional poverty varies considerably across different provinces,

\footnotetext{
${ }^{28}$ In general, Shanghai has a much higher GDP per capita than Liaoning and Guangdong; Liaoning and Guangdong have a much higher GDP per capita than Henan and Gansu. For more details see http://data.stats.gov.cn/english/easyquery.htm?cn=E0105

${ }^{29}$ Likewise, we observe similar rankings in terms of provincial income poverty, Shanghai is the least poor (with statistical significance), followed by Liaoning, Guangdong, and Henan; Gansu is the poorest (with statistical significance).
} 
illuminating the importance of considering provincial conditions, because different compositions require different policy responses.

Table 5-3: The Composition of Poverty in Large Provinces

\begin{tabular}{|c|c|c|c|c|c|c|c|c|c|c|c|c|c|}
\hline & & & & & Comp & positio & $\mathrm{n}[$ censc & ored he & adcour & nt ratic & $\mathrm{O}, \%]$ & & \\
\hline & $\begin{array}{l}\text { Sampl } \\
\text { e size }\end{array}$ & MPI & $\mathrm{H}(\%)$ & A $(\%)$ & YS & SY & $\mathrm{CM}$ & $\mathrm{N}$ & $\mathrm{E}$ & S & W & $\mathrm{CF}$ & A \\
\hline 2010 & & & & & & & & & & & & & \\
\hline & & 0.011 & 2.7 & 41.5 & 1.2 & 0.8 & 0.4 & 1.7 & 0.0 & 0.6 & 2.0 & 2.1 & 1.4 \\
\hline Liaoning & 3639 & $\begin{array}{l}{[0.007,0.015} \\
]\end{array}$ & {$[1.7,3.7]$} & $\begin{array}{l}{[39.1,43.9} \\
]\end{array}$ & $\begin{array}{l}{[0.7,1.8} \\
]\end{array}$ & $\begin{array}{l}{[0.1,1.5} \\
]\end{array}$ & $\begin{array}{l}{[0.0,0.8} \\
]\end{array}$ & {$[1.0,2.5]$} & $\begin{array}{l}{[0.0,0.0} \\
]\end{array}$ & ]$^{[0.0,1.2}$ & {$[1.1,2.8]$} & {$[1.2,3.1]$} & $\begin{array}{l}{[0.7,2.0} \\
]\end{array}$ \\
\hline & & 0.003 & 0.8 & 36.1 & 0.1 & 0.4 & 0.3 & 0.8 & 0.0 & 0.1 & 0.1 & 0.1 & 0.0 \\
\hline Shanghai & 3475 & $\begin{array}{l}{[0.001,0.005} \\
]\end{array}$ & {$[0.3,1.3]$} & $\begin{array}{l}{[33.4,38.7} \\
]\end{array}$ & $\begin{array}{l}{[0.0,0.2} \\
]\end{array}$ & $\begin{array}{l}{[0.0,0.8} \\
]\end{array}$ & $\begin{array}{l}{[0.0,0.7} \\
]\end{array}$ & {$[0.3,1.3]$} & $\begin{array}{l}{[0.0,0.0} \\
]\end{array}$ & $\begin{array}{l}{[0.0,0.4} \\
]\end{array}$ & {$[0.0,0.3]$} & {$[0.0,0.2]$} & $\begin{array}{l}{[0.0,0.1} \\
]\end{array}$ \\
\hline & & 0.026 & 6.3 & 41.1 & 2.5 & 0.9 & 1.9 & 4.2 & 0.0 & 2.4 & 5.4 & 5.7 & 1.6 \\
\hline Henan & 4973 & $\begin{array}{l}{[0.017,0.035} \\
]\end{array}$ & {$[4.3,8.3]$} & $\begin{array}{l}{[39.1,43.1} \\
]\end{array}$ & $\begin{array}{l}{[1.6,3.4} \\
]\end{array}$ & ]$^{[0.3,1.5}$ & $\begin{array}{l}{[0.7,3.0} \\
]\end{array}$ & {$[2.5,5.9]$} & $\begin{array}{l}{[0.0,0.1} \\
]\end{array}$ & $\begin{array}{l}{[1.0,3.9} \\
]\end{array}$ & {$[3.3,7.4]$} & {$[3.7,7.6]$} & $\begin{array}{l}{[1.0,2.3} \\
]\end{array}$ \\
\hline & & 0.034 & 8.6 & 39.9 & 2.9 & 2.2 & 1.3 & 7.3 & 0.1 & 3.9 & 5.8 & 5.6 & 1.6 \\
\hline $\begin{array}{l}\text { Guangdon } \\
\text { g }\end{array}$ & 4128 & $\begin{array}{l}{[0.024,0.044} \\
]\end{array}$ & $\begin{array}{l}{[6.1,11.0} \\
]\end{array}$ & $\begin{array}{l}{[38.4,41.5} \\
]\end{array}$ & $\begin{array}{l}{[1.7,4.2} \\
]\end{array}$ & $\begin{array}{l}{[1.3,3.1} \\
]\end{array}$ & $\begin{array}{l}{[0.3,2.2} \\
]\end{array}$ & {$[5.1,9.5]$} & ]$^{[0.0,0.1}$ & $\begin{array}{l}{[2.1,5.8} \\
]\end{array}$ & {$[3.4,8.2]$} & {$[3.4,7.9]$} & $\begin{array}{l}{[0.9,2.3} \\
]\end{array}$ \\
\hline & & 0.052 & 12.6 & 41.4 & 6.3 & 2.5 & 1.4 & 9.2 & 0.2 & 5.7 & 9.3 & 12.0 & 2.3 \\
\hline Gansu & 4853 & {$[0.035,0.069$} & {$[8.5,16.6$} & {$[40.3,42.6$} & {$[3.9,8.8$} & {$[0.8,4.1$} & {$[0.6,2.3$} & {$[6.3,12.1$} & {$[0.0,0.5$} & {$[2.7,8.6$} & {$[5.9,12.8$} & {$[8.1,15.9$} & {$[1.3,3.2$} \\
\hline 2012 & & & & & & & & & & & & & \\
\hline & & 0.005 & 1.3 & 0.5 & 0.8 & 0.3 & 0.0 & 1.0 & 0.0 & 0.0 & 0.9 & 1.1 & 0.8 \\
\hline Liaoning & 3538 & $\begin{array}{l}{[0.002,0.008} \\
]\end{array}$ & {$[0.6,2.0]$} & $\begin{array}{l}{[39.7,43.2} \\
]\end{array}$ & $\begin{array}{l}{[0.4,1.3} \\
]\end{array}$ & $\begin{array}{l}{[0.0,0.6} \\
]\end{array}$ & {$[0,0.1]$} & {$[0.4,1.6]$} & $\begin{array}{l}{[0.0,0.0} \\
]\end{array}$ & ]$^{[0.0,0.0}$ & {$[0.3,1.5]$} & {$[0.5,1.8]$} & $\begin{array}{l}{[0.3,1.3} \\
]\end{array}$ \\
\hline & & 0.009 & 2.1 & 0.9 & 0.0 & 0.1 & 0.2 & 2.1 & 0.0 & 1.8 & 1.8 & 1.8 & 1.8 \\
\hline Shanghai & 2666 & $\begin{array}{l}{[0.000,0.024} \\
]\end{array}$ & {$[0.0,5.5]$} & $\begin{array}{l}{[39.3,44.5} \\
]\end{array}$ & $\begin{array}{l}{[0.0,0.0} \\
]\end{array}$ & $\begin{array}{l}{[0.0,0.2} \\
]\end{array}$ & {$[0,0.5]$} & {$[0.0,5.5]$} & $\begin{array}{l}{[0.0,0.0} \\
]\end{array}$ & ]$^{[0.0,5.2}$ & {$[0.0,5.2]$} & {$[0.0,5.2]$} & $\begin{array}{l}{[0.0,5.2} \\
]\end{array}$ \\
\hline & & 0.020 & 4.6 & 2.0 & 1.6 & 1.6 & 1.7 & 3.4 & 0.0 & 0.9 & 4.0 & 3.3 & 0.9 \\
\hline Henan & 5631 & {$[0.012,0.028$} & {$[2.8,6.4]$} & ]$^{[41.2,45.1}$ & ]$^{[0.9,2.3}$ & ]$^{[0.6,2.5}$ & $\begin{array}{l}{[0.5,2.8} \\
]^{[}\end{array}$ & {$[1.8,5.0]$} & $\begin{array}{l}{[0.0,0.0} \\
]\end{array}$ & $\begin{array}{l}{[0.0,1.9} \\
]\end{array}$ & {$[2.2,5.7]$} & {$[1.8,4.9]$} & ]$^{[0.5,1.3}$ \\
\hline Guangdon & 4520 & 0.022 & 5.3 & 2.2 & 1.7 & 1.6 & 1.3 & 4.7 & 0.0 & 1.3 & 3.6 & 3.5 & 1.1 \\
\hline
\end{tabular}




\begin{tabular}{|c|c|c|c|c|c|c|c|c|c|c|c|c|c|}
\hline $\mathrm{g}$ & & {$[0.013,0.03]$} & {$[3.4,7.2]$} & $\begin{array}{l}{[38.5,43.4} \\
]\end{array}$ & ]$^{[0.8,2.6}$ & $\begin{array}{l}{[0.4,2.9} \\
]\end{array}$ & $\begin{array}{l}{[0.6,1.9} \\
]\end{array}$ & {$[2.8,6.5]$} & $\begin{array}{l}{[0.0,0.1} \\
]\end{array}$ & $\begin{array}{l}{[0.3,2.3} \\
]\end{array}$ & {$[1.7,5.4]$} & {$[1.8,5.2]$} & $\begin{array}{l}{[0.4,1.8} \\
]\end{array}$ \\
\hline & & 0.029 & 7.0 & 2.9 & 3.5 & 1.1 & 1.0 & 5.7 & 0.0 & 2.5 & 4.5 & 6.3 & 1.5 \\
\hline Gansu & 5768 & $\begin{array}{l}{[0.018,0.039} \\
]\end{array}$ & {$[4.5,9.5]$} & $\begin{array}{l}{[39.4,42.6} \\
]\end{array}$ & ]$^{[2.0,5.0}$ & $\begin{array}{l}{[0.4,1.8} \\
]\end{array}$ & ]$^{[0.4,1.5}$ & {$[3.5,8.2]$} & ]$^{[0.0,0.0}$ & $\begin{array}{l}{[0.8,4.3} \\
]\end{array}$ & {$[2.5,6.6]$} & {$[4.1,8.5]$} & $\begin{array}{l}{[0.8,2.1} \\
]\end{array}$ \\
\hline \multicolumn{14}{|l|}{2014} \\
\hline \multirow[b]{2}{*}{ Liaoning } & \multirow[b]{2}{*}{3616} & 0.004 & 0.9 & 42.3 & 0.7 & 0.2 & 0.3 & 0.5 & 0.0 & 0.0 & 0.5 & 0.7 & 0.3 \\
\hline & & $\begin{array}{l}{[0.001,0.006} \\
]\end{array}$ & {$[0.3,1.5]$} & $\begin{array}{l}{[38.6,46.0} \\
]\end{array}$ & $\begin{array}{l}{[0.2,1.1} \\
]\end{array}$ & $\begin{array}{l}{[0.0,0.5} \\
]\end{array}$ & $\begin{array}{l}{[0.0,0.6} \\
]\end{array}$ & {$[0.1,0.9]$} & $\begin{array}{l}{[0.0,0.0} \\
]\end{array}$ & $\begin{array}{l}{[0.0,0.1} \\
]\end{array}$ & {$[0.1,0.8]$} & {$[0.3,1.1]$} & $\begin{array}{l}{[0.1,0.4} \\
]\end{array}$ \\
\hline \multirow[b]{2}{*}{ Shanghai } & \multirow[b]{2}{*}{2477} & 0.001 & 0.4 & 34.6 & 0.1 & 0.0 & 0.3 & 0.3 & 0.0 & 0.0 & 0.0 & 0.1 & 0.0 \\
\hline & & $\begin{array}{l}{[0.000,0.003} \\
]\end{array}$ & {$[0.0,0.7]$} & $\begin{array}{l}{[32.2,37.1} \\
]\end{array}$ & ]$^{[0.0,0.2}$ & $\begin{array}{l}{[0.0,0.0} \\
]\end{array}$ & $\begin{array}{l}{[0.0,0.6} \\
]^{2}\end{array}$ & {$[0.0,0.7]$} & ]$^{[0.0,0.0}$ & $\begin{array}{l}{[0.0,0.1} \\
]\end{array}$ & {$[0.0,0.1]$} & {$[0.0,0.2]$} & $\begin{array}{l}{[0.0,0.1} \\
]\end{array}$ \\
\hline \multirow[b]{2}{*}{ Henan } & \multirow[b]{2}{*}{5819} & 0.013 & 3.1 & 41.3 & 0.6 & 1.6 & 1.4 & 2.6 & 0.0 & 0.1 & 1.4 & 2.0 & 0.5 \\
\hline & & $\begin{array}{l}{[0.008,0.018} \\
]\end{array}$ & {$[1.9,4.3]$} & $\begin{array}{l}{[38.8,43.7} \\
]\end{array}$ & $\begin{array}{l}{[0.3,0.8} \\
]\end{array}$ & $\begin{array}{l}{[0.7,2.6} \\
]\end{array}$ & $\begin{array}{l}{[0.7,2.1} \\
]\end{array}$ & {$[1.4,3.7]$} & $\begin{array}{l}{[0.0,0.0} \\
]\end{array}$ & $\begin{array}{l}{[0.0,0.2} \\
]\end{array}$ & {$[0.6,2.2]$} & {$[1.0,3.0]$} & $\begin{array}{l}{[0.1,0.8} \\
]\end{array}$ \\
\hline \multirow[b]{2}{*}{$\begin{array}{l}\text { Guangdon } \\
\text { g }\end{array}$} & \multirow[b]{2}{*}{4280} & 0.017 & 4.2 & 41.7 & 1.2 & 1.9 & 1.5 & 3.9 & 0.0 & 0.5 & 2 & 2.2 & 0.4 \\
\hline & & ]$^{[0.011,0.024}$ & {$[2.7,5.7]$} & $\begin{array}{l}{[39.8,43.7} \\
]\end{array}$ & $\begin{array}{l}{[0.5,1.9} \\
]\end{array}$ & $\begin{array}{l}{[0.9,2.9} \\
]\end{array}$ & $\begin{array}{l}{[0.6,2.4} \\
]\end{array}$ & {$[2.4,5.3]$} & ]$^{[0.0,0.0}$ & $\begin{array}{l}{[0.1,0.8} \\
]\end{array}$ & {$[1.0,2.9]$} & {$[1.0,3.3]$} & $\begin{array}{l}{[0.1,0.7} \\
]\end{array}$ \\
\hline \multirow[b]{2}{*}{ Gansu } & \multirow[b]{2}{*}{5739} & 0.023 & 5.3 & 43.1 & 3.1 & 1.3 & 0.9 & 4.4 & 0.0 & 2.0 & 2.6 & 5.0 & 0.6 \\
\hline & & $\begin{array}{l}{[0.012,0.034} \\
]\end{array}$ & {$[2.8,7.9]$} & $\begin{array}{l}{[41.2,45.0} \\
]\end{array}$ & $\begin{array}{l}{[1.3,4.8} \\
]\end{array}$ & $\begin{array}{l}{[0.2,2.4} \\
]\end{array}$ & $\begin{array}{l}{[0.4,1.4} \\
]\end{array}$ & {$[2.3,6.5]$} & $\begin{array}{l}{[0.0,0.0} \\
]\end{array}$ & $\begin{array}{l}{[0.5,3.4} \\
]\end{array}$ & {$[1.2,4.1]$} & {$[2.5,7.4]$} & $\begin{array}{l}{[0.1,1.1} \\
]\end{array}$ \\
\hline
\end{tabular}

\subsection{MPI by Social Groups}

What else do we know about MPI poor people in China? In this section, we disaggregate MPI by population subgroups that vary according to household characteristics/socioeconomic status. The subgroups selected are usually studied for income poverty. Part of the analysis presented should only be considered to be illustrative because the standard errors are high, but they indicate relationships worth

exploring.

Age: The Sustainable Development Goals require the MPI - the measure of poverty in all its dimensions - to be disaggregated by age. UNICEF defines a child as a person aged 0-17, so we define three population groups, children, adults 18-60 years of age, and those 61 and above. By the CFPS sample, $21 \%$ of the population are children. Their poverty is not significantly different from adults at the 5\% level, but at 10\% they are significantly poorer, although those aged 61 and above are the poorest. The good news is that poverty in all three age groups decreased significantly 2010 2014. Child poverty fell from $9.7 \%$ in 2010 to $4 \%$ in 2014 (Child MPI from 0.42 to 0.17). And elder poverty plummeted from $15 \%$ to $5.6 \%$, even as the share of elders in the population increased slightly. This positive finding suggests that no age cohort is being left behind and that the poorest two - elders and children - are included in MPI reduction. 
Table 5-4 Poverty Comparison: Age Cohort of the Population

\begin{tabular}{|c|c|c|c|c|c|c|c|c|c|c|c|}
\hline & & $\begin{array}{l}\text { populatio } \\
\text { n share }\end{array}$ & MPI & $\mathrm{ub}$ & $\mathrm{lb}$ & $\mathrm{H}$ & $\mathrm{ub}$ & $\mathrm{lb}$ & A & ub & $\mathrm{lb}$ \\
\hline \multirow{6}{*}{2010} & 017 & 2006 & 0.04 & 0.05 & 0.03 & $070 /$ & 12.1 & 740 & 43.6 & 44.9 & 42.4 \\
\hline & $0-17$ & 20.90 & & & & 9.170 & & 1.470 & & & \\
\hline & & & 0.02 & 0.03 & 0.02 & & & & 42.2 & 43.4 & 40.9 \\
\hline & $18-60$ & 66.1 & 7 & 3 & 1 & $6.3 \%$ & $7.6 \%$ & $5.0 \%$ & $\%$ & $\%$ & $\%$ \\
\hline & 61 and & & 0.06 & 0.07 & 0.05 & 15.0 & 17.5 & 12.5 & 41.5 & 42.5 & 40.5 \\
\hline & above & 12.93 & 2 & 3 & 1 & $\%$ & $\%$ & $\%$ & $\%$ & $\%$ & $\%$ \\
\hline \multirow{6}{*}{2012} & & & 0.03 & 0.04 & 0.02 & & 10.1 & & 44.7 & 48.5 & 40.8 \\
\hline & 0-17 & 20.43 & 4 & 8 & 1 & $7.7 \%$ & $\%$ & $5.2 \%$ & $\%$ & $\%$ & $\%$ \\
\hline & & & 0.01 & 0.02 & 0.01 & & & & 42.8 & 45.5 & 40.1 \\
\hline & $18-60$ & 67.11 & 7 & 3 & 2 & $4.0 \%$ & $5.1 \%$ & $2.9 \%$ & $\%$ & $\%$ & $\%$ \\
\hline & 61 and & & 0.03 & 0.04 & 0.03 & & 11.1 & & 41.0 & 42.6 & 39.5 \\
\hline & above & 12.46 & 9 & 6 & 1 & $9.4 \%$ & $\%$ & $7.8 \%$ & $\%$ & $\%$ & $\%$ \\
\hline \multirow{5}{*}{2014} & & & 0.01 & 0.02 & 0.01 & & & & 43.1 & 45.0 & 41.3 \\
\hline & $0-17$ & 18.4 & 7 & 3 & 1 & $4.0 \%$ & $5.3 \%$ & $2.7 \%$ & $\%$ & $\%$ & $\%$ \\
\hline & & & 0.01 & 0.01 & 0.00 & & & & 41.1 & 42.2 & 40.0 \\
\hline & $18-60$ & 67.16 & 1 & 3 & 8 & $2.6 \%$ & $3.2 \%$ & $2.0 \%$ & $\%$ & $\%$ & $\%$ \\
\hline & $\begin{array}{l}61 \text { and } \\
\text { above }\end{array}$ & 14.44 & $\begin{array}{l}0.02 \\
4\end{array}$ & $\begin{array}{l}0.02 \\
8\end{array}$ & $\begin{array}{l}0.01 \\
9\end{array}$ & $5.6 \%$ & $6.6 \%$ & $4.6 \%$ & $\begin{array}{l}42.2 \\
\%\end{array}$ & $\begin{array}{l}43.1 \\
\%\end{array}$ & $\begin{array}{l}41.3 \\
\%\end{array}$ \\
\hline
\end{tabular}

Given that household heads tend to make proportionately more decisions (Bilenkisi et al., 2015), we start by looking at them by gender.

Gender of household head ${ }^{30}$ Intuitively, female-headed households are thought to be poorer due to women's disadvantages in the labor market, discrimination, low productivity, or low education. ${ }^{31}$ But

${ }^{30}$ CFPS does not directly gather data on head of household in the questionnaire. To determine the household head, we assumed that the male would be the household head, as is traditional in China, unless the woman had a significantly higher income, in which case, she was considered the household head.

31 See Pearce (1978), McLanahan (1985), Smith (1988), Sen (1989), Appleton (1996), Okojie (2002), and Deutsch and Silber (2005). 
in our dataset, there is no statistically significant difference in poverty between genders. The absolute changes of MPI and H from 2010 to 2014 are similar. Inspired by Buvinić and Gupta (1997), we did other explorations - exploring the heads' marriage status (e.g. 'female -maintained', 'female-led', 'single-parent', 'male-absent'), gender and marriage status (see Appendix D), and gender differences under different migration actions (see Appendix E) ${ }^{32}$. Again, there are no statistically significant differences.

Does this mean there are no gender differences at all? We cannot support such a statement since our analysis does not focus on the individual level. In most developing countries, women may head a house for two possible reasons: either they have the means to live independently or males are absent but sending remittances - women in such households could show lower poverty rates (World Bank, 2016).

Table 5-4 Poverty Comparison: Gender of the Household Head

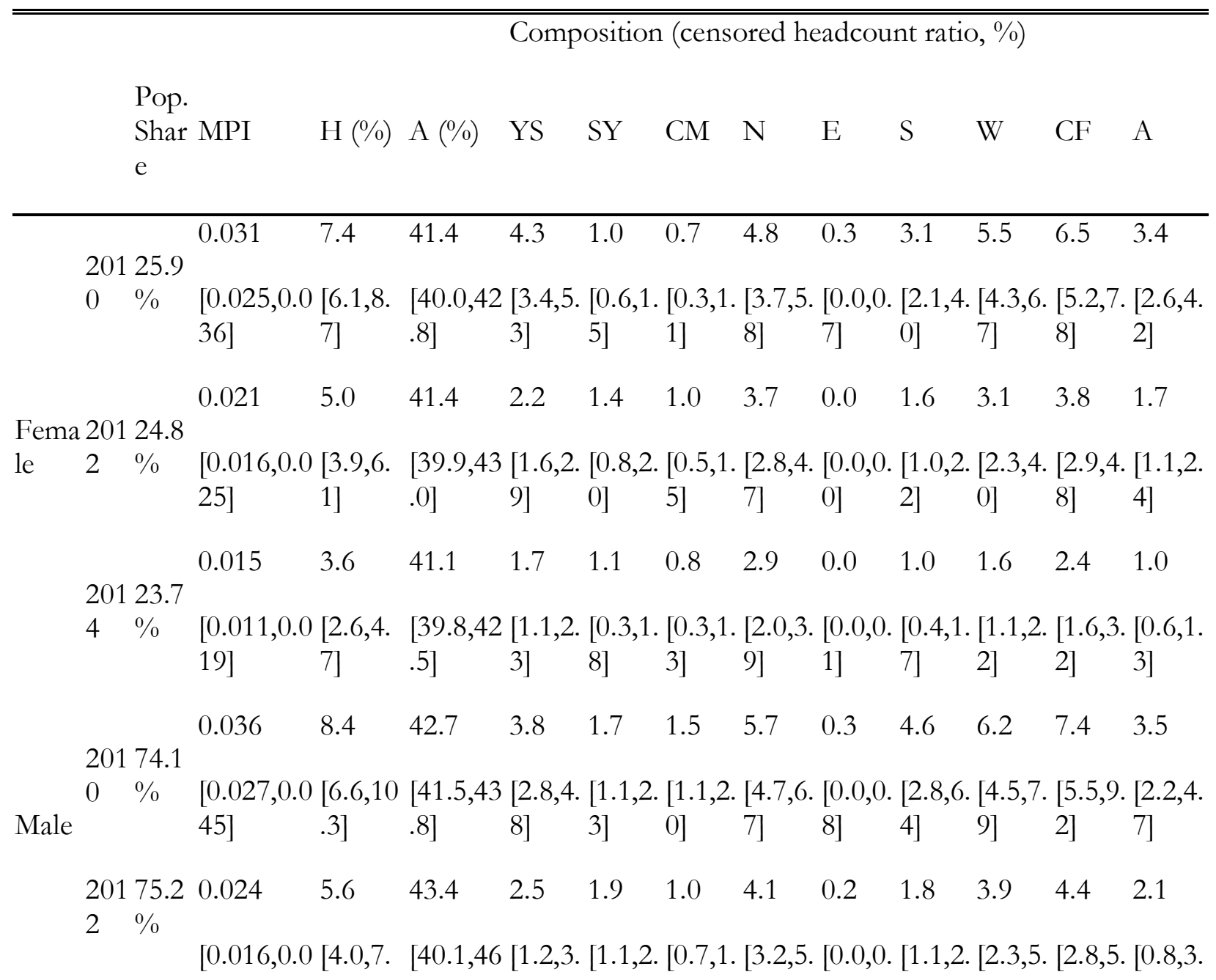

\footnotetext{
32 Another argument is that women who are working away from the household tend to send a higher proportion of their income, although their salaries might be lower than men's. What is more, female migrants often send remittances to the person (often a woman) taking care of her children (UN-INSTRAW, 2007) or the household (UN-INSTRAW, 2008a).
} 


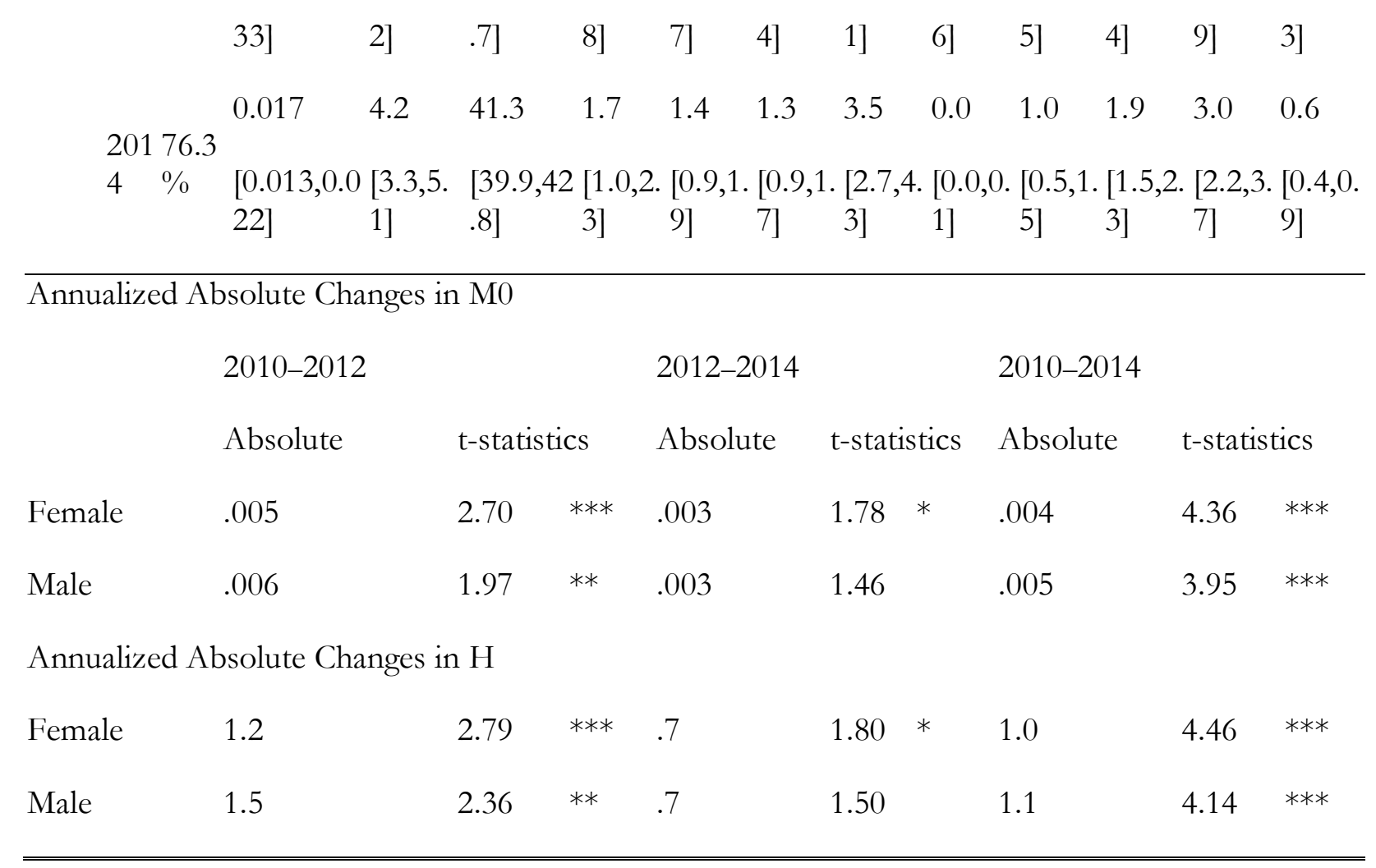

In terms of marital status, our results suggest divorced or widowed families are significantly poorer, suggesting 'male/female-absent' families may also be poorer. In addition, we find that most of the divorced/widowed families are female-headed, and they are more likely to be deprived in years of schooling, school attendance, nutrition, water, cooking fuel, and assets. Finally, poverty decreased from 2010 to 2014 for all subgroups, but the reduction was fastest for single or divorced/widowed families, which is a positive and equalizing finding. However, note that the population share of these groups is too small for us to claim that the data are representative; we merely indicate topics for future study.

Table 5-5 Poverty Level and Composition: Marital Status of Household Heads

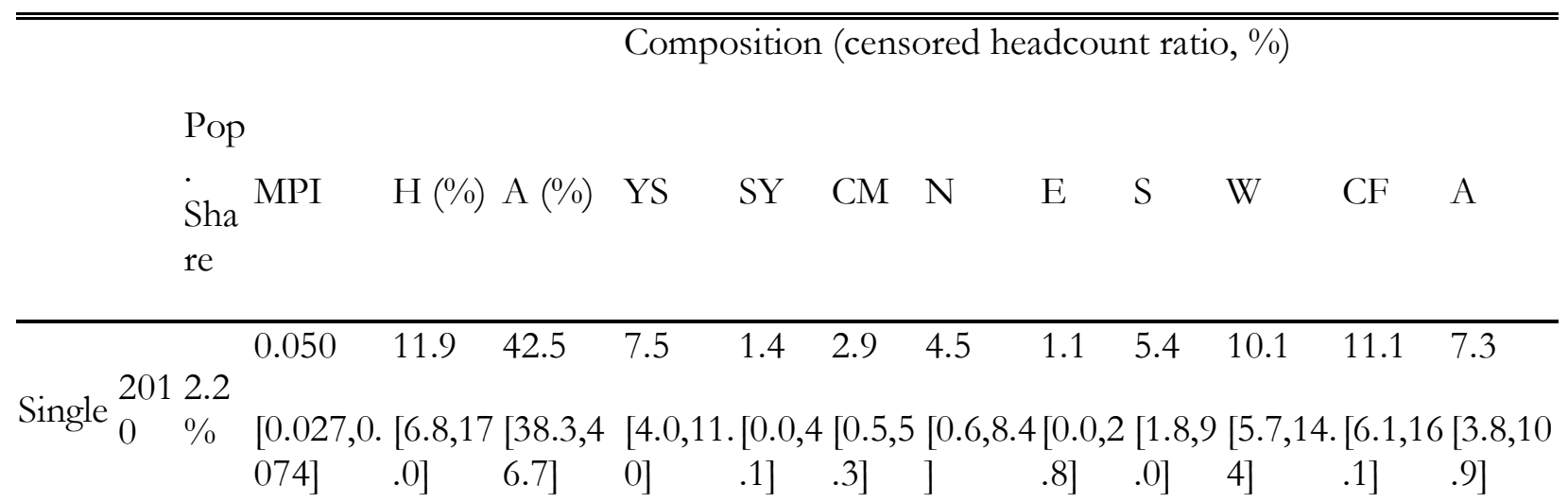




\section{$\begin{array}{llllllllllll}0.027 & 5.9 & 45.2 & 3.4 & 0.0 & 1.7 & 4.0 & 0.2 & 2.6 & 5.5 & 5.5 & 3.2\end{array}$}

2012.0

$2 \% \quad[0.011,0 .[2.7,9 .[39.8,5][1.1,5.8[0.0,0[0.1,3[1.2,6.9[0.1,0[0.2,5[2.3,8.7[2.3,8 .[0.9,5$.

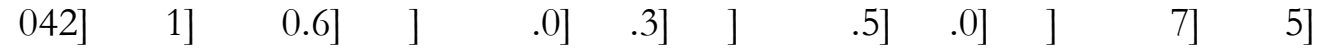

2013.4

$$
\begin{array}{llllllllllll}
0.018 & 4.3 & 42.0 & 2.5 & 0.4 & 0.6 & 3.2 & 0.2 & 0.9 & 2.9 & 3.9 & 2.2
\end{array}
$$

$4 \% \quad[0.009,0 .[2.2,6 .[39.4,4][0.9,4.2[0.0,1[0.0,1[1.3,5.1[0.1,0[0.1,1[1.2,4.6[1.9,5 .[0.8,3$.

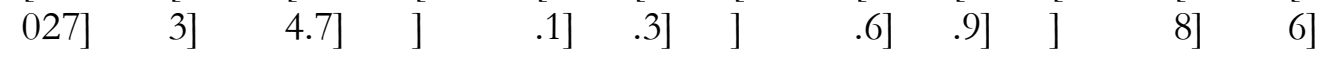

20192.3

$$
\begin{array}{llllllllllll}
0.032 & 7.6 & 42.3 & 3.5 & 1.5 & 1.2 & 5.3 & 0.3 & 4.0 & 5.6 & 6.7 & 3.0
\end{array}
$$

Marri $0 \quad \% \quad[0.025,0 .[6.1,9$. [41.2,4 [2.7,4.4[1.0,1 [0.9,1 [4.4,6.2 [0.1,0 [2.6,5 [4.2,6.9 [5.1,8. [2.0,4.

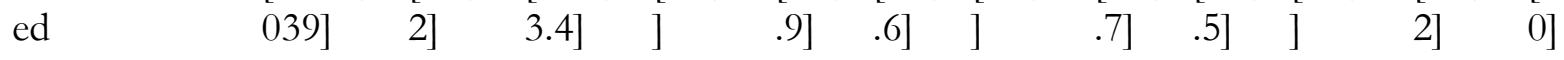
or $\quad \begin{array}{rrrrrrrrrrrr}0.022 & 5.1 & 43.1 & 2.2 & 1.8 & 0.9 & 3.9 & 0.1 & 1.7 & 3.4 & 3.9 & 1.7\end{array}$ 20191.6

Coha $2 \% \quad[0.015,0 .[3.8,6$. [40.2,4 [1.2,3.2 [1.2,2 [0.6,1 [3.1,4.7 [0.1,0 [1.1,2 [2.2,4.7 [2.6,5. [0.7,2.

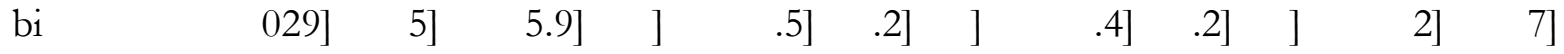
tation 20189.9

$$
\begin{array}{llllllllllll}
0.016 & 3.8 & 41.3 & 1.4 & 1.3 & 1.2 & 3.2 & 0.0 & 0.9 & 1.6 & 2.6 & 0.6
\end{array}
$$

$4 \% \quad[0.012,0 .[3.0,4 .[40.0,4] 0.9,1.9[0.8,1[0.9,1[2.5,3.9[0.0,0[0.5,1[1.3,2.0[1.9,3 .[0.3,0$.

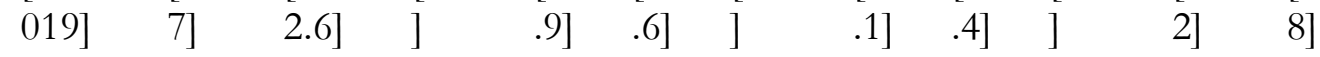

2015.6

$\begin{array}{llllllllllll}0.066 & 15.4 & 42.5 & 9.1 & 2.9 & 2.3 & 7.8 & 0.3 & 6.8 & 12.6 & 14.0 & 9.3\end{array}$

$0 \% \quad[0.049,0 .[11.8,1[40.9,4][6.8,11 .[0.8,5[0.5,4[5.2,10 \cdot[0.3,1[3.7,9[9.3,15 .[10.6,1[6.7,11$

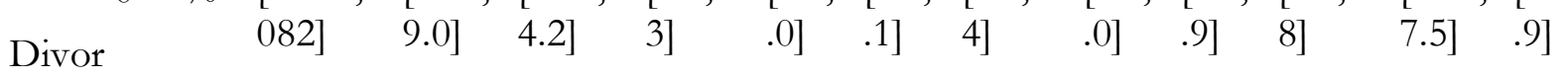
$\begin{array}{lllllllllllll}\text { ced } & 0.040 & 9.6 & 41.8 & 5.5 & 1.7 & 2.0 & 5.5 & 0.2 & 2.8 & 6.6 & 8.1 & 5.8\end{array}$ $\begin{array}{lll}\text { or } & 2016.5 & 0\end{array} \quad[0.028,0 .[6.9,12[38.8,4][3.4,7.5[0.3,3[0.8,3[3.6,7.4[0.0,0[1.4,4[4.2,9.0[5.5,10[3.5,8$.

Wido

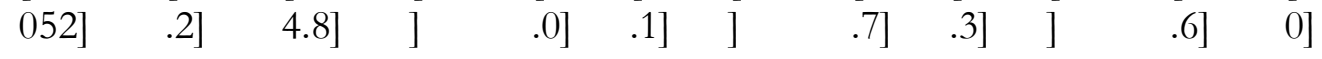

wed

2016.8

$$
\begin{array}{llllllllllll}
0.031 & 7.4 & 41.3 & 4.3 & 1.4 & 1.4 & 5.8 & 0.0 & 2.3 & 4.1 & 5.7 & 1.8
\end{array}
$$

\begin{tabular}{|c|c|c|c|c|c|c|c|c|}
\hline \multirow[b]{3}{*}{ Single } & \multicolumn{3}{|c|}{ 2010-2012 } & \multicolumn{2}{|c|}{ 2012-2014 } & \multicolumn{3}{|c|}{ 2010-2014 } \\
\hline & Absolute & t-sta & ics & Absolute & t-statistics & Absolute & t-stat & tics \\
\hline & 0.013 & 1.74 & $*$ & 0.004 & 0.93 & 0.008 & 2.64 & $* * *$ \\
\hline Married or & 0.005 & 2.09 & ** & 0.003 & 1.63 & 0.004 & 4.24 & *** \\
\hline
\end{tabular}

$4 \% \quad[0.021,0 .[5.1,9 .[39.3,4][2.6,6.0[0.3,2[0.7,2[3.6,7.9[0.0,0[0.8,3[2.3,5.9[3.5,7 .[1.1,2$.

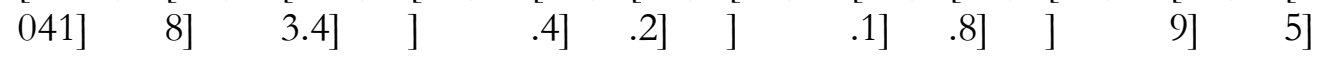

Annualized Absolute Changes in M0 
Cohabitation

Divorced or

Widowed

0.013

$2.48 \quad * * \quad 0.005$

1.15

0.009

$3.61 * * *$

Annualized Absolute Changes in $\mathrm{H}$

\begin{tabular}{lccccccccc} 
Single & 2.9 & 2.59 & $* * *$ & 0.8 & 0.82 & 2.0 & 2.83 & $* * *$ \\
$\begin{array}{l}\text { Married or } \\
\text { Cohabitation }\end{array}$ & 1.3 & 2.49 & $* *$ & 0.7 & $1.68 *$ & 1.0 & 4.43 & $* * *$ \\
$\begin{array}{l}\text { Divorced or } \\
\text { Widowed }\end{array}$ & 3.2 & 2.06 & $* *$ & 1.1 & 1.19 & 2.0 & 3.67 & $* * *$ \\
\hline
\end{tabular}

Education of housebold head: As expected, there is an inverse relationship between MPI and the education level of household heads. The results suggest that people who are living with illiterate household heads experience the greatest levels of poverty. Poverty tends to decrease as the educational level of the head of household increases. The highest education group has the lowest poverty rate, but the '7-9' and ' 9 and above' groups are not significantly different from each other. The policy implication could be that education is important in helping people get out of poverty and stay out of poverty; education for children thus may be important for reducing the intergenerational transmission of poverty.

In terms of changes over time, the proportion of people who are living with illiterate household heads is decreasing; their poverty is decreasing across time mainly due to decreased deprivations in years of schooling, electricity, sanitation, cooking fuel, and assets. For the more highly educated subgroups, because their censored headcount ratios are already quite low, there is no significant reduction across indicators. More highly educated groups are less likely to be deprived in school attendance or in health-related indicators. This may be because household heads with higher education levels tend to invest in human capital for themselves and their children.

Table 5-6 Poverty Level and Composition: Education Level of the Household Head

\begin{tabular}{|c|c|c|c|c|c|c|c|c|c|c|c|c|c|}
\hline & Pop & & \multicolumn{11}{|c|}{ Composition (censored headcount ratio, $\%$ ) } \\
\hline & $\begin{array}{l}\text { Sha } \\
\text { re }\end{array}$ & MPI & $\mathrm{H}(\%)$ & $\mathrm{A}(\%)$ & YS & SY & $\mathrm{CM}$ & $\mathrm{N}$ & $\mathrm{E}$ & S & W & $\mathrm{CF}$ & A \\
\hline $\begin{array}{ll}\text { No } & \\
& 20\end{array}$ & 17.6 & 0.104 & 23.7 & 43.7 & 18.7 & 3.5 & 2.0 & 11.6 & 0.8 & 12.1 & 17.7 & 22.0 & 13.5 \\
\hline $\begin{array}{l}\text { educat } 10 \\
\text { ion }\end{array}$ & $\%$ & $\begin{array}{l}{[0.083} \\
125]\end{array}$ & $\begin{array}{l}{[19.5,2} \\
8.0]\end{array}$ & $\begin{array}{l}{[42.2,4} \\
5.3]\end{array}$ & $\begin{array}{l}{[15.4,2} \\
2.1]\end{array}$ & $\begin{array}{l}{[1.5} \\
5.5]\end{array}$ & $\begin{array}{l}{[1.2,} \\
2.8]\end{array}$ & $\begin{array}{l}{[9.6,1} \\
3.6]\end{array}$ & $\begin{array}{l}{[0.1,} \\
1.6]\end{array}$ & $\begin{array}{l}{[7.5,1} \\
6.6]\end{array}$ & $\begin{array}{l}{[13.7,2} \\
1.7]\end{array}$ & $\begin{array}{l}{[17.7,2} \\
6.3]\end{array}$ & $\begin{array}{l}{[10.4,1} \\
6.6]\end{array}$ \\
\hline
\end{tabular}


2017.1

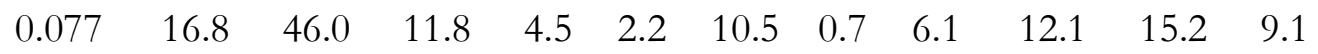

$12 \% \quad[0.044,0 .[10.9,2[41.9,5[6.7,17[1.1,[1.1,[7.4,1][0.0,[3.6,8 .[6.1,18[9.1,21[3.9,14$ $\begin{array}{llllllllllll}111] & 2.8] & 0.0] & .0] & 7.9] & 3.2] & 3.7] & 2.1] & 6 & \text {.2] } & \text {.3] } & \text {.3] }\end{array}$

2016.4

$\begin{array}{llllllllllll}0.058 & 13.5 & 42.6 & 8.6 & 3.6 & 2.9 & 10.1 & 0.2 & 3.7 & 5.8 & 10.4 & 3.2\end{array}$

$14 \% \quad[0.043,0 .[10.4,1][41.0,4[5.8,11[1.9,[1.8,[7.6,1][0.0,[1.8,5 .[4.4,7].[7.6,13[2.1,4$.

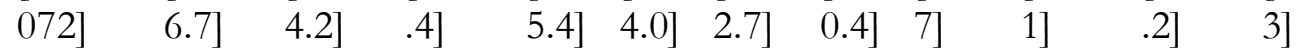

2028.6

$\begin{array}{llllllllllll}0.038 & 9.0 & 41.9 & 2.3 & 1.8 & 2.1 & 7.5 & 0.5 & 4.7 & 6.8 & 7.6 & 2.9\end{array}$

$10 \% \quad[0.028,0 .[6.8,11[40.7,4[1.5,3] 1.2,.[1.3,[5.9,9 .[0.0,[2.5,6 .[4.8,8 .[5.4,9 .[1.5,4$.

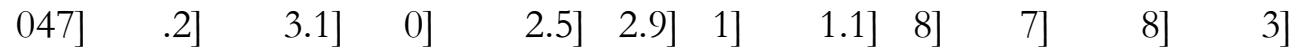

$\begin{array}{llllllllllll}0.021 & 5.3 & 40.6 & 1.4 & 2.1 & 1.0 & 4.3 & 0.1 & 1.5 & 3.5 & 3.8 & 1.2\end{array}$

2030.4

$12 \% \quad[0.017,0 .[4.1,6 .[39.7,4$ [0.8,1. [1.4, [0.5, [3.3,5. [0.1, [0.9,2. [2.5,4. [2.8,4. [0.7,1.

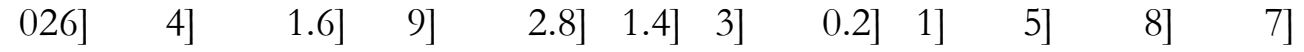

2029.7

$\begin{array}{llllllllllll}0.014 & 3.5 & 41.0 & 0.8 & 1.2 & 1.3 & 3.0 & 0.0 & 0.9 & 1.8 & 2.6 & 0.4\end{array}$

$14 \% \quad[0.011,0 .[2.7,4 .[39.7,4[0.5,1] 0.7,.[0.8,[2.2,3 .[0.0,[0.5,1 .[1.2,2 .[1.8,3 .[0.2,0$.

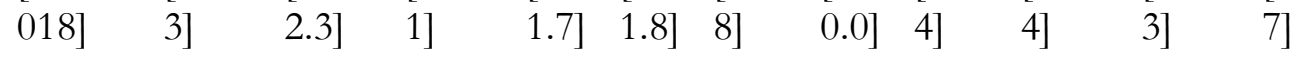

$\begin{array}{llllllllllll}0.013 & 3.3 & 39.4 & 0.0 & 1.0 & 0.7 & 3.0 & 0.1 & 1.9 & 2.4 & 2.9 & 0.6\end{array}$

2032.3

$10 \% \quad[0.010,0 .[2.4,4 .[38.3,4[0.0,0].[0.6,[0.3,[2.2,3 .[0.0,[1.2,2 .[1.6,3 .[2.1,3 .[0.3,1$.

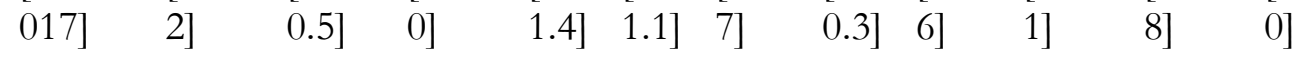

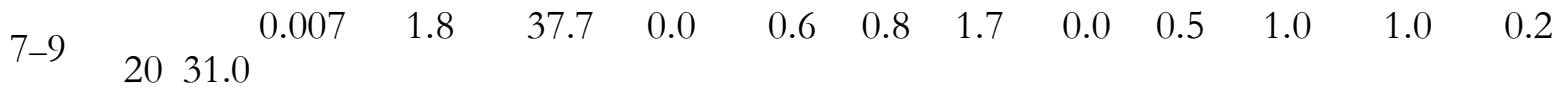

years

$12 \% \quad[0.004,0 .[1.2,2] 36.0,.3[0.0,0 .[0.2,[0.3,[1.0,2 .[0.0,[0.2,0 .[0.6,1 .[0.5,1 .[0.0,0$.

$\begin{array}{llllllllllll}009] & 5] & 9.4] & 0] & 1.1] & 1.2] & 3] & 0.0] & 8] & 5] & 4] & 3]\end{array}$

2030.8

$\begin{array}{llllllllllll}0.008 & 2.0 & 38.4 & 0.0 & 0.9 & 0.7 & 2.0 & 0.0 & 0.4 & 0.7 & 0.9 & 0.2\end{array}$

$14 \% \quad[0.004,0 .[1.1,2 .[36.8,4[0.0,0] 0.1,.[0.3,[1.1,2 .[0.0,[0.1,0 .[0.4,1 .[0.4,1 .[0.0,0$.

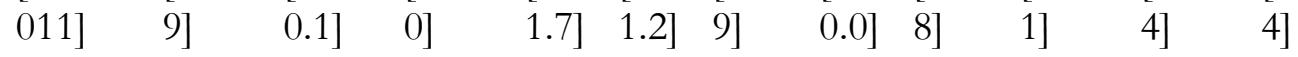

2021.5

$\begin{array}{llllllllllll}0.006 & 1.5 & 38.5 & 0.0 & 0.3 & 0.7 & 1.5 & 0.0 & 0.6 & 1.0 & 0.9 & 0.2\end{array}$

$9 \quad 10 \% \quad[0.003,0 .[0.9,2 .[36.0,4[0.0,0 .[0.0,[0.2,[0.8,2 .[0.0,[0.3,1 .[0.5,1 .[0.4,1 .[0.1,0$.

years

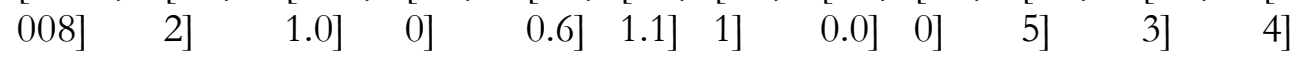

above 2021.5

$\begin{array}{llllllllllll}0.007 & 1.7 & 37.6 & 0.0 & 0.9 & 0.5 & 1.7 & 0.0 & 0.5 & 0.9 & 0.7 & 0.1\end{array}$

$12 \% \quad[0.004,0 .[1.0,2] 35.0,.4[0.0,0] 0.3,.[0.1,[1.0,2 .[0.0,[0.1,0 .[0.4,1 .[0.3,1 .[0.0,0$.

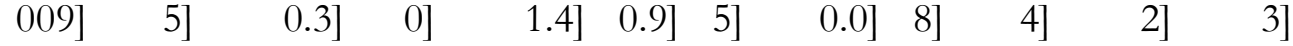



0.003
$0.9 \quad 37.7 \quad 0.0$
$\begin{array}{lll}0.2 & 0.6 & 0.9\end{array}$
$0.0 \quad 0.0$
0.4
$0.3 \quad 0.1$

2023.0

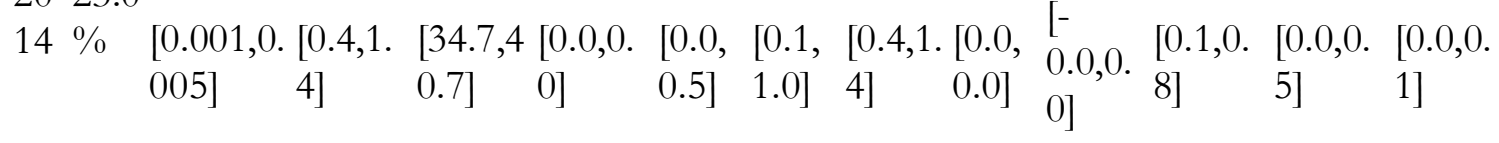

\begin{tabular}{|c|c|c|c|c|c|c|c|c|c|}
\hline \multicolumn{10}{|c|}{ Annualized Absolute Changes in M0 } \\
\hline & \multicolumn{3}{|c|}{ 2010-2012 } & \multicolumn{3}{|c|}{$2012-2014$} & \multicolumn{3}{|l|}{ 2010-2014 } \\
\hline & Absolute & \multicolumn{2}{|c|}{ t-statistics } & Absolute & \multicolumn{2}{|c|}{ t-statistics } & Absolute & \multicolumn{2}{|c|}{ t-statistics } \\
\hline No education & 0.003 & 2.92 & $* * *$ & 0.000 & 0.31 & & 0.001 & 2.29 & $* *$ \\
\hline $1-6$ years & 0.000 & 0.26 & & 0.002 & 1.82 & $*$ & 0.001 & 1.66 & $*$ \\
\hline $7-9$ years & 0.013 & 1.34 & & 0.012 & 1.36 & & 0.013 & 4.08 & $* * *$ \\
\hline 9 years above & 0.008 & 3.05 & $* * *$ & 0.003 & 2.39 & $* *$ & 0.006 & 4.55 & $* * *$ \\
\hline \multicolumn{10}{|c|}{ Annualized absolute changes of $\mathrm{H}$} \\
\hline No education & 0.8 & 2.72 & $* * *$ & -0.1 & 0.24 & & 0.4 & 2.16 & $* *$ \\
\hline 1-6 years & -0.1 & 0.34 & & 0.4 & 1.83 & $*$ & 0.2 & 1.64 & \\
\hline $7-9$ years & 3.5 & 1.89 & * & 2.3 & 1.34 & & 2.9 & 4.43 & $* * *$ \\
\hline 9 years above & 1.9 & 3.06 & $* * *$ & 0.9 & 2.48 & $* *$ & 1.4 & 4.71 & $* * *$ \\
\hline
\end{tabular}

Age of household head: According to Okojie (2002), the age of the household head influences household welfare in an inverse U-shaped relationship. Welfare initially increases with age because workers can acquire more human capital (education and experience) as they grow older; however, income and welfare may subsequently fall due to retirement or productivity decline.

In order to test this relationship, we draw the poverty distribution graphs for monetary poverty and MPI according to the age of the household head. While remaining mindful of the small sample size, you can see in Figure 5.2 that the relationship also follows the inverse- $U$ logic. The youngest household heads (mainly between 16 to 18 years old) are quite poor in both poverty measurements. ${ }^{33}$ Then poverty falls until 24 years of age, where it reaches its lowest point, and stabilizes at 35 years of age. Between the ages of 36 and 60 , poverty fluctuates in a fixed range.

\footnotetext{
33 According to Marriage Law of the People's Republic of China, No marriage may be contracted before the man has reached 22 years of age and the woman 20 years of age. Early marriages are illegal and mostly come from bad customs. We consider that the young heads might come from poorer families or do not have the necessary abilities to raise the families yet.
} 
After 60 years of age, poverty rises again. Based on this, we set up three age groups for the household heads: 16-35 years old, 36-60 years old, and 61 years old and above.

Figure 5-2: Poverty Headcount Ratios in Terms of Monetary Poor and MPI
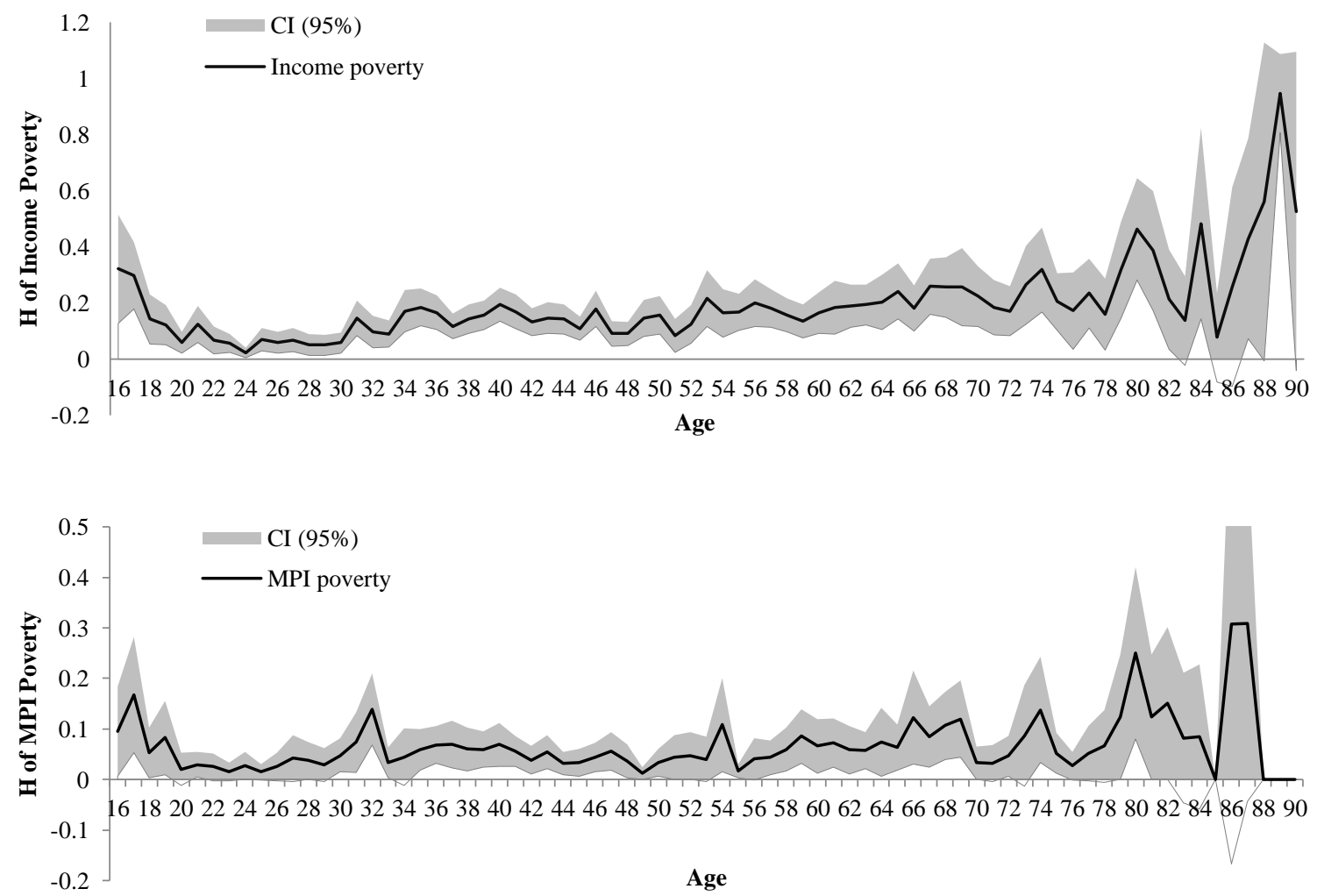

According to the results, people living with 36- to 60-year-old household heads are the least likely to be poor. The poorest households are those headed by the elderly group. As expected, the oldest group is highly deprived in almost all the indicators. They are rarely deprived in school attendance due to the fact that older people usually do not live with their grandchildren. But they are consistently deprived in years of schooling, nutrition, and living standard. This generation was born before China's liberation with scarce economic and social welfare resources. In terms of the composition of poverty, households with elderly heads of household have improved as fast as other groups, especially in living standards, which is a good sign of the equalizing trends of the current social anti-poverty projects. Comparing the annualized absolute changes in MPI and $\mathrm{H}$ for each subgroup, all the groups' poverty levels decrease from 2010 to 2014, especially the oldest - and poorest - group. 
Table 5.7 Poverty Comparison: Age of the Household Head

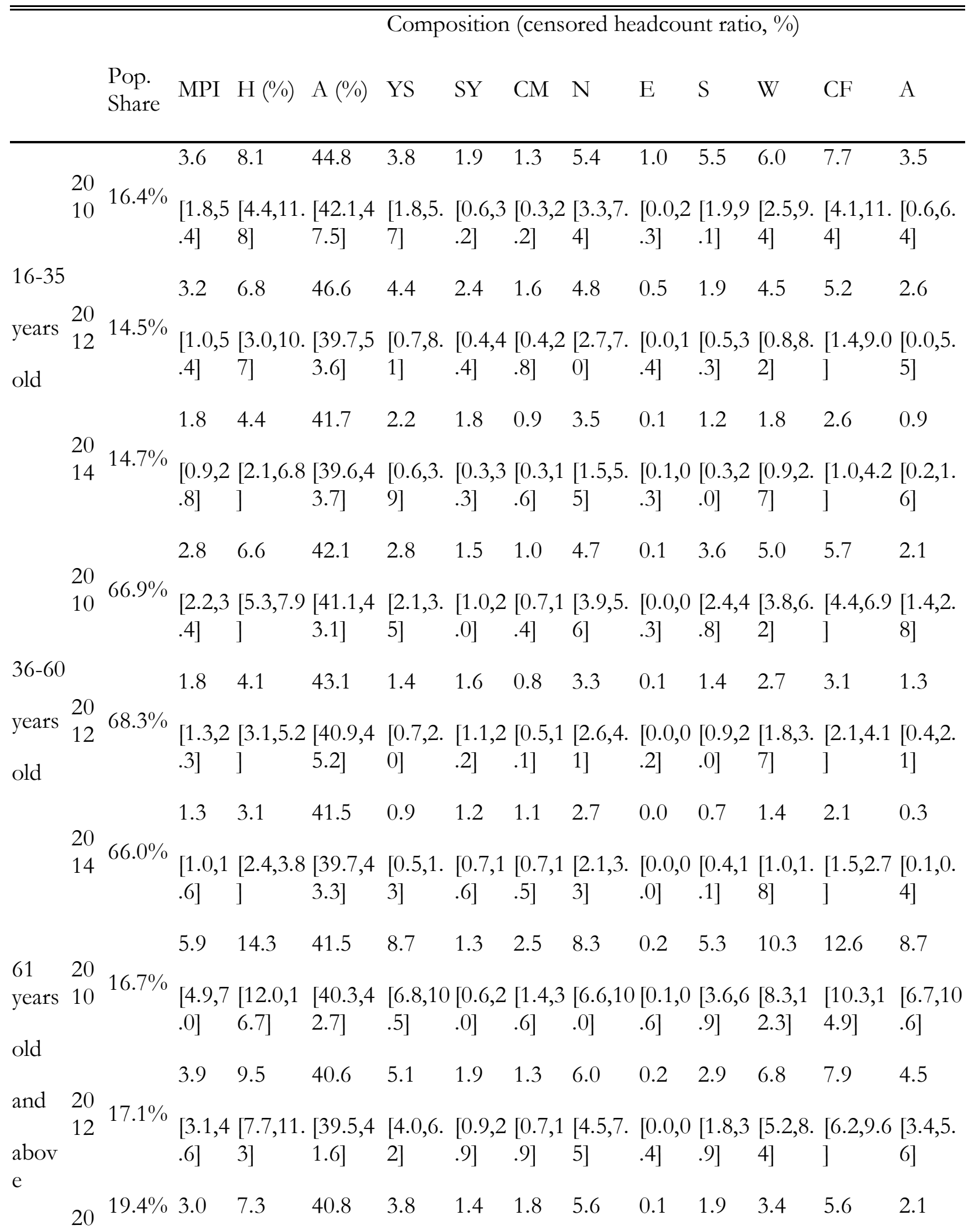


Annualized Absolute Changes in M0

\begin{tabular}{|c|c|c|c|c|c|c|c|c|c|}
\hline & $2010-2012$ & & & $2012-201$ & & & 2010-201 & & \\
\hline & Absolute & t-stati & & Absolute & t-stat & istics & Absolute & t-stat & tics \\
\hline $16-35$ years old & 0.002 & 0.31 & & 0.007 & 1.09 & & 0.004 & 1.72 & * \\
\hline $36-60$ years old & 0.005 & 2.69 & $* * *$ & 0.003 & 1.67 & $*$ & 0.004 & 4.70 & $* * *$ \\
\hline $\begin{array}{l}61 \text { years old and } \\
\text { above }\end{array}$ & 0.010 & 3.24 & $* * *$ & 0.004 & 1.78 & $*$ & 0.007 & 4.83 & $* * *$ \\
\hline Annualized Abs & lute Chang & & & & & & & & \\
\hline 16-35 years old & 0.6 & 0.47 & & 1.2 & 1.04 & & 0.9 & 1.65 & $*$ \\
\hline 36-60 years old & 1.3 & 3.07 & $* * *$ & 0.5 & 1.69 & $*$ & 0.9 & 4.92 & $* * *$ \\
\hline $\begin{array}{l}61 \text { years old and } \\
\text { above }\end{array}$ & 2.4 & 3.19 & $* * *$ & 1.1 & 1.85 & $*$ & 1.8 & 4.95 & $* * *$ \\
\hline
\end{tabular}

Migrant status. The bukou system ${ }^{34}$ is often regarded as a caste system in China (Chan and Zhang, 1999; Young, 2013). It causes issues of discrimination (Kuang and Liu, 2012), inequality, and monetary poverty (Park and Wang, 2010; Zhang et al., 2015).

How does hukou affect multidimensional poverty? Our data suggest people living with rural hukou household heads are more likely to be poor. If we compare rural and urban composition results, the rural hukou group is less deprived in living standard indicators compared to people who live in rural areas (see Table 5-1). Rural migration could be one of the possible explanations for this. Comparing the poverty changes from 2010 to 2014, the rural hukou group has a statistically significant decrease, but the urban hukou group's improvement is not significant.

\footnotetext{
${ }^{34}$ Hukou is a record in the system of household registration required by law in China. It is an institution controlling population movement.
} 
Table 5.8 Poverty Comparison: Hukou Status of the Household Head

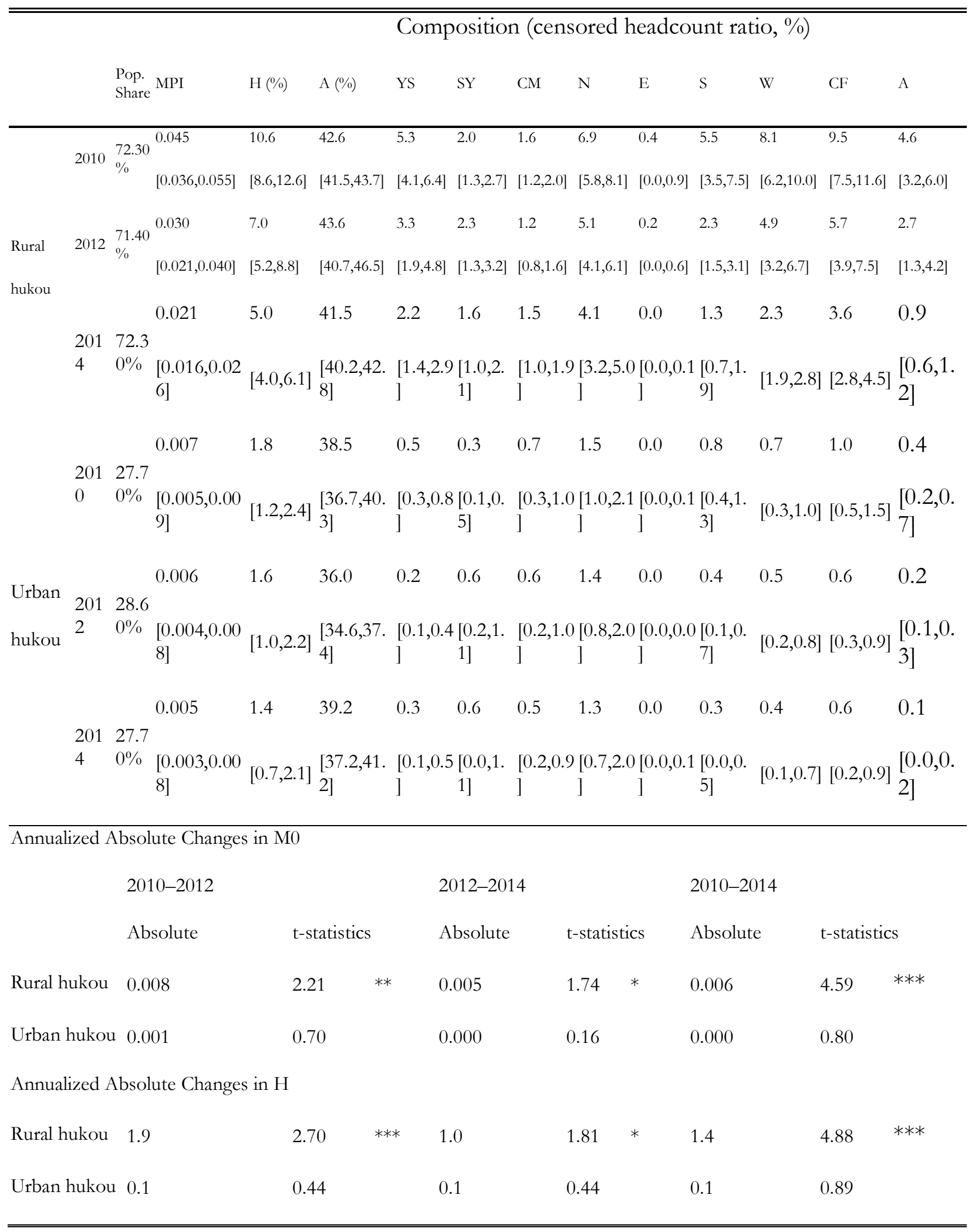


In terms of rural migrants, over the past 30 years, China has experienced massive internal migration. ${ }^{35}$ Though rural migrants are able to escape income poverty (罗楚亮, 2010; Du, Park, and Wang, 2005) non-monetary dimensions prove challenging. Because the informal migrant workers cannot register in the city, they are not able to enjoy proper social benefits. This leads to difficulties for children's school enrolment and medical care; indirectly, the emotional well-being of the children left behind in rural areas may also suffer. ${ }^{36}$ All in all, there might be a different story of poverty from the multidimensional point of view.

Following the National Statistics Bureau's (NSB) definition of migrants, ${ }^{37}$ we divide the whole population into four groups: 1. whole family moved out - the whole family has moved from rural to urban areas; 2. rural households with partial migrants - some of the members are working outside of the rural area, while the rest remain in the rural area; 3. rural non-migrants - rural residents who have not migrated; and 4. urban non-migrants - urban residents.

The results show that group 3 is the poorest, followed by group 2. Group 4 is the least poor of all. We deduce that migration has a strong effect in reducing multidimensional poverty. In particular, the 'whole family moved out' category has the strongest effects.

How should we understand the possible linkage between migration and low MPI? We have three hypotheses: 1. economic drivers suggest that families with higher income levels can easily access multiple resources and reduce multidimensional poverty; 2 . human capital indicates that migrants who can migrate usually already have better education or are healthier, meaning they have a lower MPI in advance; and 3. environmental change, which assumes that changing location from the rural to urban can automatically reduce MPI. To explore the 'economic drivers' effect, we compare CHRs on education and living standard dimensions and focus on the differences between migrants and rural non-migrants. As expected, we find poverty in group 1 is significantly lower than in group 3 . But, quite unexpectedly, CHRs are higher in group 2 than in group 3. One possible explanation could come from the left-behind children/elderly people issue, and this calls for thinking about how to reduce poverty in order to avoid polarization. To explore the human capital effect, we focus on indicators of years of schooling and nutrition and compare rural migrants and rural non-migrants. The results suggest that years of schooling is strongly associated with migration, but this is not the case for nutrition. To test environmental change, we focus on living standard. We find that group 1 is less likely to be deprived in sanitation, water, cooking fuel, and assets compared to group 2 or group 3, which verified our test. In sum, migration is associated with lower multidimensional poverty, potentially through complicated mechanisms. From the policy point of view, in order to harness migration to reduce multidimensional poverty, policies should reinforce education while creating equal opportunities for migrants to enjoy the social welfare system. Still, the poorest group

\footnotetext{
35 According to National Bureau of Statistics, there were more than 263 million migrants (approximately $20 \%$ of the population) in 2012. See http://www.stats.gov.cn/tjsj/zxfb/201305/t20130527_12978.html [Chinese].

36 UNDP (2013), Ren and Treiman (2013), and Xu and Xie (2013).

${ }^{37}$ According to the NSB, rural migrants are rural residents holding rural hukou who work on non-agriculture locally, or who leave their home communities for work for more than 6 months. More specifically, rural migrants can be divided into three categories: local migrants, who work within the same village/county in which he/she is registered; outside migrants, who work outside the county in which he/she is registered; and whole families who leave their place of registry to work and live in another area. We put the first and second types together in this paper.
} 
is non-migrants, so schemes to stimulate rural livelihoods and to encourage the return of skilled migrants to rural areas may be explored as well.

In terms of annualized changes, we only observe statistically significant decreases for non-migrants from 2010-2012 and 2010-2014, but not for migrants, suggesting the migrants' improvements over time are not statistically significant.

Table 5.9 Poverty Comparison: Migration Action

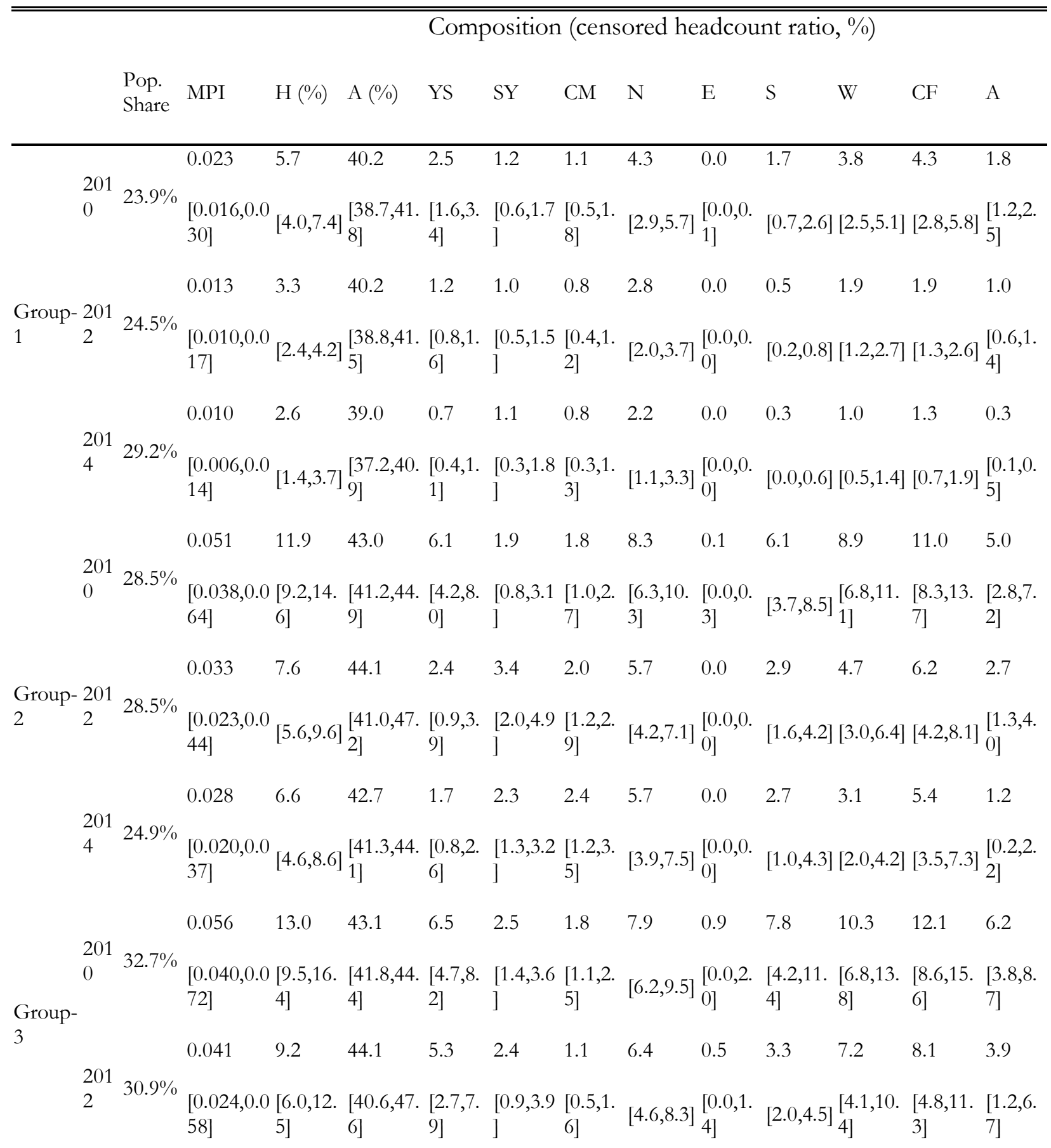




\begin{tabular}{|c|c|c|c|c|c|c|c|c|c|c|c|c|c|}
\hline & & 0.027 & 6.5 & 41.9 & 3.7 & 1.6 & 1.6 & 5.0 & 0.1 & 1.5 & 3.2 & 4.9 & 1.4 \\
\hline 4 & $\begin{array}{l}201 \\
4\end{array} 29.6 \%$ & $\begin{array}{l}{[0.020,0.0} \\
35]\end{array}$ & {$[4.8,8.2$} & 2] ${ }_{7]}^{[40.0,43 .}$ & $\begin{array}{l}{[2.3,5 .} \\
1]\end{array}$ & $\begin{array}{l}{[0.7,2.6} \\
]\end{array}$ & $\begin{array}{l}{[1.0,2 .} \\
2]\end{array}$ & {$[3.7,6.4]$} & $\begin{array}{l}{[0.0,0 .} \\
2]\end{array}$ & {$[0.7,2.3]$} & {$[2.4,4.0]$} & {$[3.4,6.4]$} & $\begin{array}{l}{[0.9,1 .} \\
9]\end{array}$ \\
\hline & & 0.005 & 1.5 & 37.4 & 0.4 & 0.3 & 0.5 & 1.3 & 0.0 & 0.6 & 0.5 & 0.7 & 0.2 \\
\hline & $\begin{array}{l}201 \\
0\end{array} 24.9 \%$ & $\begin{array}{l}{[0.003,0.0} \\
08]\end{array}$ & {$[0.9,2.0$} & o] $\begin{array}{l}{[35.6,39 .} \\
3]\end{array}$ & $\begin{array}{l}{[0.2,0 .} \\
6]\end{array}$ & $\begin{array}{l}{[0.1,0.5} \\
]\end{array}$ & $\begin{array}{l}{[0.2,0 .} \\
8]\end{array}$ & {$[0.8,1.8]$} & $\begin{array}{l}{[0.0,0 .} \\
0]\end{array}$ & {$[0.2,1.0]$} & {$[0.1,0.8]$} & {$[0.3,1.0]$} & $\begin{array}{l}{[0.1,0 .} \\
4]\end{array}$ \\
\hline & & 0.005 & 1.4 & 35.8 & 0.3 & 0.7 & 0.4 & 1.1 & 0.0 & 0.3 & 0.3 & 0.5 & 0.2 \\
\hline Group- 2 & $20126.2 \%$ & & & & & & & & & & & & \\
\hline 2 & $2 \quad 20.2 \%$ & $\begin{array}{l}{[0.003,0.0} \\
07]\end{array}$ & {$[0.8,2.0$} & $\begin{array}{l}{[34.2,37 .} \\
4]\end{array}$ & $\begin{array}{l}{[0.1,0 .} \\
4]\end{array}$ & $\begin{array}{l}{[0.1,1.2} \\
]\end{array}$ & $\begin{array}{l}{[0.1,0 .} \\
8]\end{array}$ & {$[0.5,1.7]$} & $\begin{array}{l}{[0.0,0 .} \\
0]\end{array}$ & {$[0.1,0.5]$} & {$[0.1,0.6]$} & {$[0.2,0.7]$} & $\begin{array}{l}{[0.0,0 .} \\
3]\end{array}$ \\
\hline & & 0.006 & 1.4 & 39.1 & 0.3 & 0.5 & 0.5 & 1.3 & 0.0 & 0.3 & 0.4 & 0.6 & 0.1 \\
\hline & $\begin{array}{l}201 \\
4\end{array} 26.3 \%$ & $\begin{array}{l}{[0.003,0.0} \\
08]\end{array}$ & {$[0.7,2.1$} & ]$_{2]}^{[37.1,41 .}$ & $\begin{array}{l}{[0.1,0 .} \\
5]\end{array}$ & $\begin{array}{l}{[-} \\
0.0,1.1]\end{array}$ & $\begin{array}{l}{[0.2,0 .} \\
9]\end{array}$ & {$[0.7,2.0]$} & $\begin{array}{l}{[0.0,0 .} \\
1]\end{array}$ & {$[0.0,0.6]$} & {$[0.1,0.8]$} & {$[0.2,1.0]$} & $\begin{array}{l}{[0.0,0 .} \\
2]\end{array}$ \\
\hline Annualiz & zed Absolut & te Changes & s in M0 & & & & & & & & & & \\
\hline & & 2010-2012 & & & & 2012-2 & 2014 & & & 2010-20 & & & \\
\hline & & Absolute & & t-statistic & & Absolu & & t-statist & & Absolute & & t-statistic & \\
\hline Group-1 & & 0.008 & & 1.31 & & 0.007 & & 1.40 & & 0.007 & & 3.19 & $* * *$ \\
\hline Group-2 & & 0.000 & & 0.33 & & 0.000 & & 0.32 & & 0.000 & & 0.04 & \\
\hline Group-3 & & 0.005 & & 2.42 & $* *$ & 0.002 & & 1.09 & & 0.003 & & 3.05 & $* * *$ \\
\hline Group-4 & & 0.009 & & 2.18 & $* *$ & 0.003 & & 0.76 & & 0.006 & & 2.93 & $* * *$ \\
\hline Annualiz & ed Absolut & te Changes & in $\mathrm{H}$ & & & & & & & & & & \\
\hline Group-1 & & 1.9 & & 1.59 & & 1.4 & & 1.46 & & 1.6 & & 3.35 & $* * *$ \\
\hline Group-2 & & 0.0 & & 0.18 & & 0.0 & & 0.06 & & 0.0 & & 0.10 & \\
\hline Group-3 & & 1.2 & & 2.50 & ** & 0.4 & & 0.96 & & 0.8 & & 3.00 & $* * *$ \\
\hline Group-4 & & 2.2 & & 2.58 & $* * *$ & 0.5 & & 0.66 & & 1.3 & & 3.13 & $* * *$ \\
\hline
\end{tabular}

Note: group-1 whole family move out; group-2 rural households with partial migrants; group-3 rural non-migrants; group-4 urban non-migrants.

Household size is another common variable for studying poverty. ${ }^{38}$ While the results depend upon the equivalence scale used for monetary poverty, many studies found smaller households often indicate a higher quality of human capital (Gottschalk and Danziger, 1993; Becker, 1995). Also, smaller household size may imply more economic independence and a lower dependency ratio.

38 Bourguignon (1989), Atkinson (1992), and Gottschalk and Danziger (1993). 
At the first glance, the MPI results tell a similar story. Smaller household size is associated with lower levels of poverty, except for one- or two-member households. This is similar to the results for income poverty. ${ }^{39}$ According to the poverty composition, one- or two-member households are mainly deprived in years of schooling, assets, and cooking fuel. They are seldom deprived in childrelated indicators, as this type of household usually has no children. Larger households are more likely to be deprived in school attendance, child mortality, nutrition, water, and cooking fuel. The intensity values show that households with more than four members have higher average deprivation scores compared to three-member households; for households with six members and above, all their CHRs are higher. Finally, in terms of changes over time, there has been a substantial and statistically significant decrease in poverty for all subgroups from 2010 to 2014. Remember, however, that household size is also a cultural issue, with rural areas and ethnic minorities having higher household sizes. Thus it is not clear whether household size alone affects MPI levels - or only in combination with these other features.

\section{Poverty Table 5.10: Poverty Comparison: Household Size}

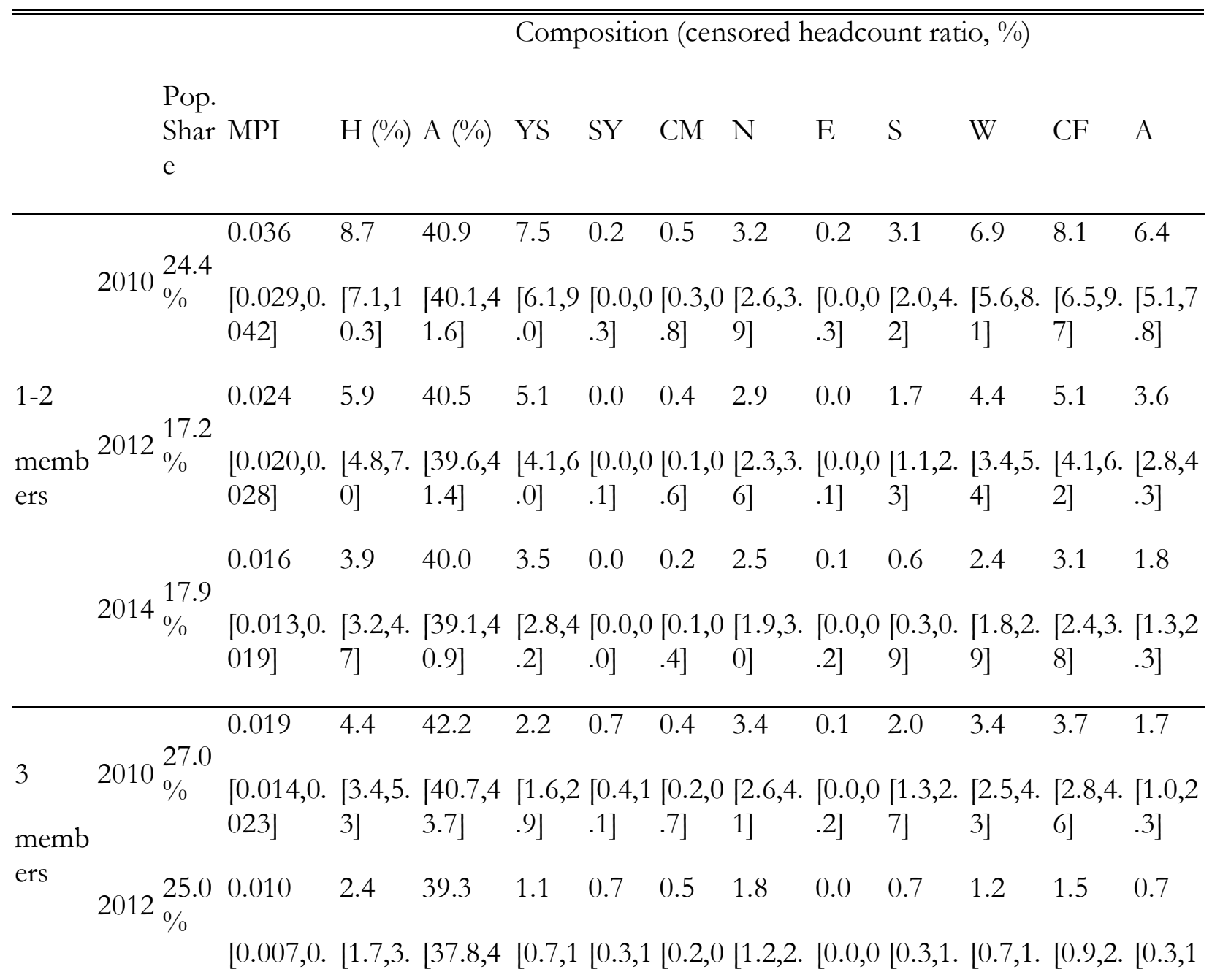

\footnotetext{
${ }^{39}$ For instance, 罗楚亮 (2010) find that the larger the household size, the poorer the group in terms of income poverty; but one- and two-member families also belong to the poorer groups.
} 


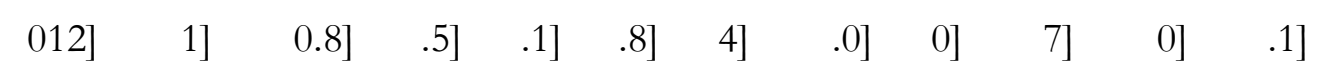

$\begin{array}{llllllllllll}0.007 & 1.7 & 41.5 & 0.8 & 0.4 & 0.4 & 1.5 & 0.0 & 0.4 & 1.0 & 1.1 & 0.3\end{array}$ $2014 \underset{\%}{23.8}[0.005,0$. [ [1.2,2. [39.9, 4 [0.4,1 [0.2,0 [0.2,0 [1.0,2. [0.0,0 [0.1,0. [0.6,1. [0.7,1. [0.1,0

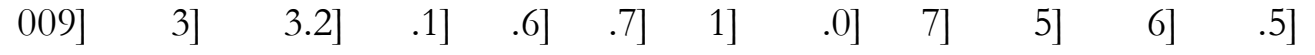

\begin{tabular}{|c|c|c|c|c|c|c|c|c|c|c|c|c|c|}
\hline \multirow{3}{*}{\multicolumn{2}{|c|}{$2010 \%$}} & 0.031 & 7.4 & 42.2 & 2.8 & 1.9 & 0.8 & 6.0 & 0.3 & 4.1 & 5.5 & 6.3 & 2.1 \\
\hline & & {$[0.024,0$.} & $5.7,9$. & {$[40.6,4$} & {$[1.8,3$} & {$[1.2,2$} & $2[0.4,1$ & {$[4.6,7$.} & {$[0.0,0$} & $0[2.6,5$. & {$[3.9,7$} & {$[4.6,8$.} & {$[1.0,3$} \\
\hline & & 039] & $2]$ & $3.7]$ & $.9]$ & .6] & $.3]$ & 4] & $.6]$ & 6] & $0]$ & $0]$ & .1] \\
\hline \multirow{6}{*}{$\begin{array}{l}4 \\
\text { memb } \\
\text { ers }\end{array}$} & & 0.020 & 4.9 & 41.8 & 1.9 & 1.7 & 0.5 & 4.1 & 0.1 & 1.7 & 3.3 & 3.5 & 1.4 \\
\hline & $2012 \begin{array}{l}21.4 \\
\%\end{array}$ & {$[0.014,0$.} & {$[3.5,6$.} & {$[39.1,4$} & {$[0.9,3$} & {$[1.0,2$} & $2[0.1,0$ & {$[3.1,5$.} & {$[0.0,0$} & $0[0.9,2$. & {$[2.1,4$} & . $[2.3,4$. & {$[0.4,2$} \\
\hline & & 027] & 3] & 4.4] & .0] & .4] & $.9]$ & 2] & .4] & 5] & $5]$ & $8]$ & $.3]$ \\
\hline & & 0.010 & 2.5 & 40.5 & 0.9 & 0.8 & 0.9 & 1.9 & 0.0 & 0.8 & 1.3 & 1.6 & 0.4 \\
\hline & $2014 \underset{\%}{20.8}$ & {$[0.007,0$} & {$[1.7,3$.} & {$[38.5,4$} & $\lceil 0.4,1$ & {$[0.3,1$} & $1[0.4,1$ & {$[1.2,2$} & {$[0.0,0$} & $0[0.3,1$. & {$[0.7,1$} & {$[1.0,2$.} & {$[0.1,0$} \\
\hline & & 013] & 3] & 2.5] & $.4]$ & $.2]$ & .4] & 6] & $.0]$ & 2] & 9] & 2] & .7] \\
\hline \multirow{9}{*}{$\begin{array}{l}5 \\
\text { memb } \\
\text { ers }\end{array}$} & & 0.040 & 9.4 & 43.1 & 2.7 & 2.6 & 2.2 & 7.5 & 0.4 & 5.1 & 6.2 & 7.9 & 3.3 \\
\hline & $2010 \begin{array}{l}15.3 \\
\%\end{array}$ & {$[0.028$} & {$[6.7 .1$} & [41.0.4 & {$[1.4,4$} & $=[1.6,3$ & $3[1.3,3$ & {$[5.4,9$.} & {$[0.0,1$} & $1[2.9$, & {$[4.0, \varepsilon$} & .55 .3 & {$[1$} \\
\hline & & 053] & 2.0] & $5.2]$ & $.0]$ & $.7]$ & $.2]$ & 6] & .1] & 3] & 4] & $0.5]$ & $.2]$ \\
\hline & & 0.021 & 4.4 & 46.9 & 1.5 & 2.4 & 1.0 & 3.6 & 0.2 & 1.5 & 3.1 & 3.7 & 1.4 \\
\hline & $2012 \%$ & {$[0.011,0$.} & {$[2.5,6$.} & {$[42.4,5$} & {$[0.2,2$} & {$[1.0,3$} & $3[0.4,1$ & {$[2.2,5$. } & {$[0.2,0$} & $0[0.6,2$. & {$[1.3,4$} &.$[1.9$ &.$[0$ \\
\hline & & 031] & 3] & $1.5]$ & $.8]$ & $.8]$ & $.5]$ & 0] & $.6]$ & 4] & 8] & $5]$ & $.7]$ \\
\hline & & 0.017 & 4.0 & 41.1 & 1.2 & 1.7 & 1.7 & 3.4 & 0.0 & 0.9 & 1.5 & 2.3 & 0.3 \\
\hline & $2014 \begin{array}{l}17.4 \\
\%\end{array}$ & {$[0.011,0$.} & {$[2.7$} & {$[38.9,4$} & {$[0.4,1$} & {$[0.7$} & $2[0.9$ & {$[2$.} & {$[0$.} & 2,1 & 8,2 . & & {$[0.0,0$} \\
\hline & & $022]$ & 3] & $3.3]$ & .9] & $.7]$ & $.5]$ & 5] & $.0]$ & 6] & 1] & 3] & $.7]$ \\
\hline \multirow{9}{*}{$\begin{array}{l}6 \\
\text { memb } \\
\text { ers } \\
\text { and }\end{array}$} & & 0.067 & 15.2 & 43.8 & 4.0 & 4.1 & 4.8 & 11.0 & 1.1 & 10.5 & 11.1 & 13.7 & 4.1 \\
\hline & $2010 \begin{array}{l}12.0 \\
\%\end{array}$ & {$[0.037,0$.} & {$[8.9,2$} & {$[41.7,4$} & {$[0.7,7$} & {$[1.6,6$} & $6[2.8,6$ & {$[7.7,1$} & {$[0.0,2$} & $2[3.9,1$ & {$[4.9,1$} & {$[7.2,2$} & {$[0.1,8$} \\
\hline & & 096] & 1.6] & 5.9] & $.3]$ & $.5]$ & .7] & 4.3] & $.6]$ & 7.1] & 7.4] & $0.1]$ & .1] \\
\hline & & 0.047 & 10.6 & 44.4 & 3.4 & 4.4 & 2.9 & 8.3 & 0.4 & 3.6 & 7.4 & 8.5 & 3.6 \\
\hline & $2012 \begin{array}{l}18.4 \\
\%\end{array}$ & {$[0.025,0$.} & {$[6.5,1$} & {$[40.4,4$} & {$[0.2,6$} & {$[2.3,6$} & $6[1.6,4$ & {$[5.8,1$} & {$[0.0,1$} & . & {$[3.5,1$} & 14 & 0.0 \\
\hline & & 069] & $4.8]$ & 8.4] & $.5]$ & $.6]$ & $.2]$ & $0.8]$ & $.2]$ & $2]$ & $1.3]$ & 2.5] & $.8]$ \\
\hline & & & & & & & & & & & & & \\
\hline & $2014 \underset{\%}{20.2}$ & 0.036 & 8.4 & 42.1 & 2.1 & 3.6 & 2.9 & 7.7 & 0.1 & 2.4 & 3.0 & 6.1 & 0.9 \\
\hline & & {$[0.024,0$.} & {$[5.7,1$} & {$[40.2,4$} & {$[0.3,4$} & {$[1.9,5$} & $5[1.8,4$ & {$[5.3,1$} & {$[0.0,0$} & $0[0.9,3$. & {$[2.0,4$} & . $[4.0,8$. & {$[0.2,1$} \\
\hline
\end{tabular}


Annualized Absolute Changes in M0

\begin{tabular}{|c|c|c|c|c|c|c|c|c|c|}
\hline & 2010-2012 & & & 2012-201 & & & 2010-201 & & \\
\hline & Absolute & t-stat & & Absolute & t-stat & stics & Absolute & t-stat & tics \\
\hline $1-2$ members & 0.006 & 2.16 & $* *$ & 0.005 & 2.86 & $* * *$ & 0.005 & 5.00 & $* * *$ \\
\hline 3 members & 0.010 & 2.48 & $* *$ & 0.002 & 0.72 & & 0.006 & 3.55 & $* * *$ \\
\hline 4 members & 0.010 & 1.05 & & 0.006 & 0.92 & & 0.008 & 1.92 & $*$ \\
\hline 5 members & 0.006 & 2.95 & $* * *$ & 0.004 & 3.06 & $* * *$ & 0.005 & 5.41 & $* * *$ \\
\hline $\begin{array}{l}6 \text { members and } \\
\text { above }\end{array}$ & 0.005 & 3.56 & $* * *$ & 0.001 & 1.31 & & 0.003 & 4.67 & $* * *$ \\
\hline Annualized Abs & olute Chan & $\mathrm{n} \mathrm{H}$ & & & & & & & \\
\hline 1-2 members & 1.3 & 2.28 & $* *$ & 1.2 & 2.98 & $* * *$ & 1.2 & 5.07 & $* * *$ \\
\hline 3 members & 2.5 & 3.04 & $* * *$ & .2 & 0.34 & & 1.4 & 3.62 & $* * *$ \\
\hline 4 members & 2.3 & 1.19 & & 1.1 & 0.86 & & 1.7 & 1.92 & $*$ \\
\hline 5 members & 1.4 & 2.94 & $* * *$ & 1.0 & 2.98 & $* * *$ & 1.2 & 5.43 & $* * *$ \\
\hline $\begin{array}{l}6 \text { members and } \\
\text { above }\end{array}$ & 1.0 & 3.32 & $* * *$ & 0.4 & 1.53 & & 0.7 & 4.80 & $* * *$ \\
\hline
\end{tabular}

In terms of ethnicity and religion, we put them together mainly because they are both culturally specific. For ethnicity, many studies suggest that ethnic minorities have higher levels of income poverty (Hannum and Xie, 1998; Bhalla and Luo, 2012; Ravallion and Jalan, 2000). In China, there are 55 ethnic minority groups (called 'non-Han'), and Han is the majority. Minorities comprised $8.5 \%$ of the population in Mainland China in $2010 .{ }^{40}$ In our dataset, if at least one household member is a minority, the whole household is defined as minority. In this case, $12-15 \%$ of the population belongs to ethnic groups. We use the same definitional method for religion (any religion) and find $18-25 \%$ of the population belong to some religious group, depending on the survey year.

The MPI results show that ethnic minorities are significantly poorer than the majority. Almost all of the indicators show higher deprivation rates among minorities. Interestingly, we do not find differences between religious and non-religious groups in terms of MPI.

40 See http://news.xinhuanet.com/english2010/china/2011-04/28/c_13849933.htm. 
Table 5.11 Poverty Comparison: Ethnicity and Religion

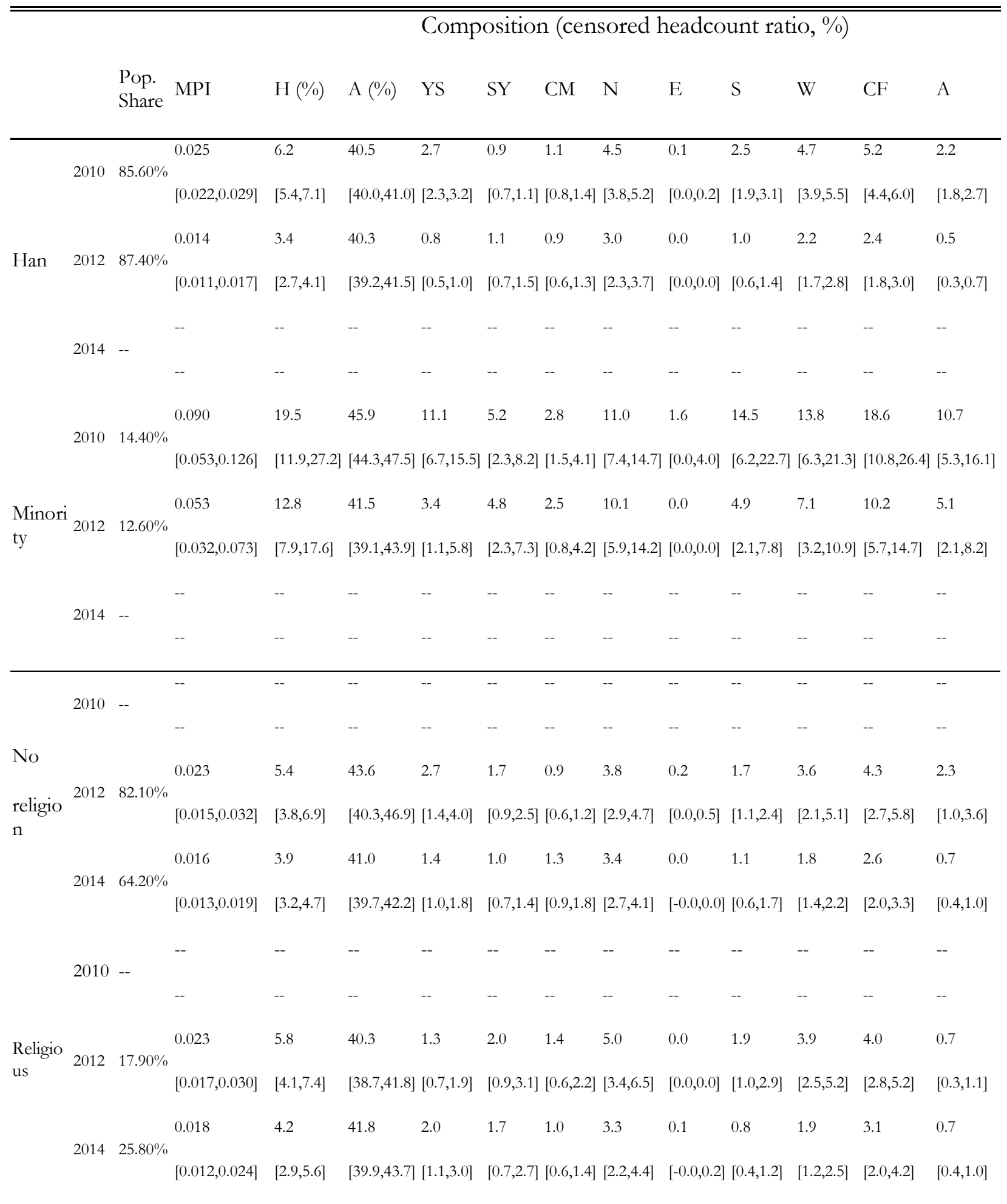

Note: There is no ethnicity variable in 2014, no religion variable in 2010. 


\section{MPI and Monetary Poverty}

\subsection{Monetary Poverty with MPI}

The CFPS includes income/expenditure aggregates for each household, thus we are able to define monetary poverty levels. Note that MPI was reduced far more than income poverty (which increased) and seems to have decreased proportionally faster than expenditure poverty in relative terms. Using the official poverty line (2300 yuan of per capita net income for rural households based on 2010 constant prices), we obtain an income poverty headcount ratio of $13.1 \%$ in $2010^{41}$ and a consumption poverty headcount ratio of $10.7 \%$. Considering the incidence of multidimensional poverty is $8.2 \%$ in the same year, we expect most of the multidimensionally poor people would also be monetarily poor. However, in fact, the mismatch is surprisingly high. Only $2.8 \%$ (with CI from $1.7 \%$ to $3.8 \%$ ) of the population are poor according to both the MPI and income poverty, and only $2.4 \%$ (with CI from 1.5\% to 3.4\%) are poor according to both the MPI and expenditure poverty. For the following years, we see similar trends.

Table 6-1 Overlap of Monetary Poverty and MPI

\begin{tabular}{|c|c|c|c|c|c|c|}
\hline & 2010 & & 2012 & & 2014 & \\
\hline & $\mathrm{H}(\%)$ & CI $(95 \%)$ & $\mathrm{H}$ & CI $(95 \%)$ & $\mathrm{H}$ & CI $(95 \%)$ \\
\hline MPI poor & 8.2 & {$[6.6,9.7]$} & 5.4 & {$[4.1,6.8]$} & 4.0 & {$[3.2,4.9]$} \\
\hline Income poor & 13.1 & {$[11.5,14.8]$} & 15.0 & $\begin{array}{l}{[13.5} \\
16.4]\end{array}$ & 15.0 & $\begin{array}{l}{[13.6,} \\
16.4]\end{array}$ \\
\hline Expenditure poor & 10.7 & {$[9.3,12.2]$} & 9.9 & {$[8.8,11.0]$} & 5.8 & {$[4.9,6.7]$} \\
\hline Overlap of income and MPI & 2.8 & {$[1.7,3.8]$} & 2.2 & {$[1.1,3.3]$} & 1.4 & {$[0.9,1.9]$} \\
\hline Overlap of expenditure and MPI & 2.4 & {$[1.5,3.4]$} & 1.3 & {$[0.9,1.8]$} & 0.8 & {$[0.4,1.1]$} \\
\hline $\begin{array}{l}\text { Proportion of overlap in MPI (income } \\
\text { measure) }\end{array}$ & $33.9 \%$ & & $40.7 \%$ & & $35.0 \%$ & \\
\hline $\begin{array}{l}\text { Proportion of overlap in MPI (expenditure } \\
\text { measure) }\end{array}$ & $29.8 \%$ & & $24.4 \%$ & & $19.4 \%$ & \\
\hline Proportion of overlap in income poverty & $21.1 \%$ & & $14.7 \%$ & & $9.4 \%$ & \\
\hline Proportion of overlap in expenditure poverty & $22.7 \%$ & & $13.3 \%$ & & $13.4 \%$ & \\
\hline
\end{tabular}

${ }^{41}$ CFPS was found to have higher rates of poverty than the official estimates (C. Zhang, Xu, Zhou, Zhang, and Xie, 2013; C. Zhang et al., 2013; Xie and Zhou, 2014). 
To investigate this mismatch further, we divide the population into five groups in terms of income/expenditure per capita, each containing roughly $20 \%$ of the population. The first quintile contains people who have the lowest income/expenditure. The fifth quintile contains the $20 \%$ of the population with the highest income/expenditure. We presume if only $8.2 \%$ of the population is MPI poor, all MPI poor people would be found among the $20 \%$ of the population that has the lowest income/expenditure in the society. However, they are not. MPI poor people exist in every quintile, even in the top quintile. ${ }^{42}$ Although we find the highest MPI incidence in the first quintile, still, the incidence of multidimensional poverty in that quintile is less than $20 \%$ in 2010 and falls to $10 \%$ in 2014 under both monetary poverty measurements. In other words, we find that less than half of MPI poor people belong to the bottom monetary quintile. This finding is surprising, even shocking, but it is not uncommon; for example, Tran et al. (2015) found that $16 \%$ of the MPI poor in Vietnam were in the top two quintiles of consumption.

If we compare the percentage contribution for each indicator to MPI by quintile (see Figure 6-1 for 2014), we find that, unlike in the first (poorest) quintile group, indicators in the living standard dimension have relatively smaller contributions to overall poverty in the higher quintiles, which makes sense as some members of this group might be able to purchase some of these items. Thus nutrition and school attendance have a relatively larger contribution to overall poverty for the monetarily richer quintiles. But even for the poorest quintile group, years of schooling and nutrition have the largest contribution to the overall poverty.

Figure 6-1 Percentage Contributions in Terms of Income Quintile

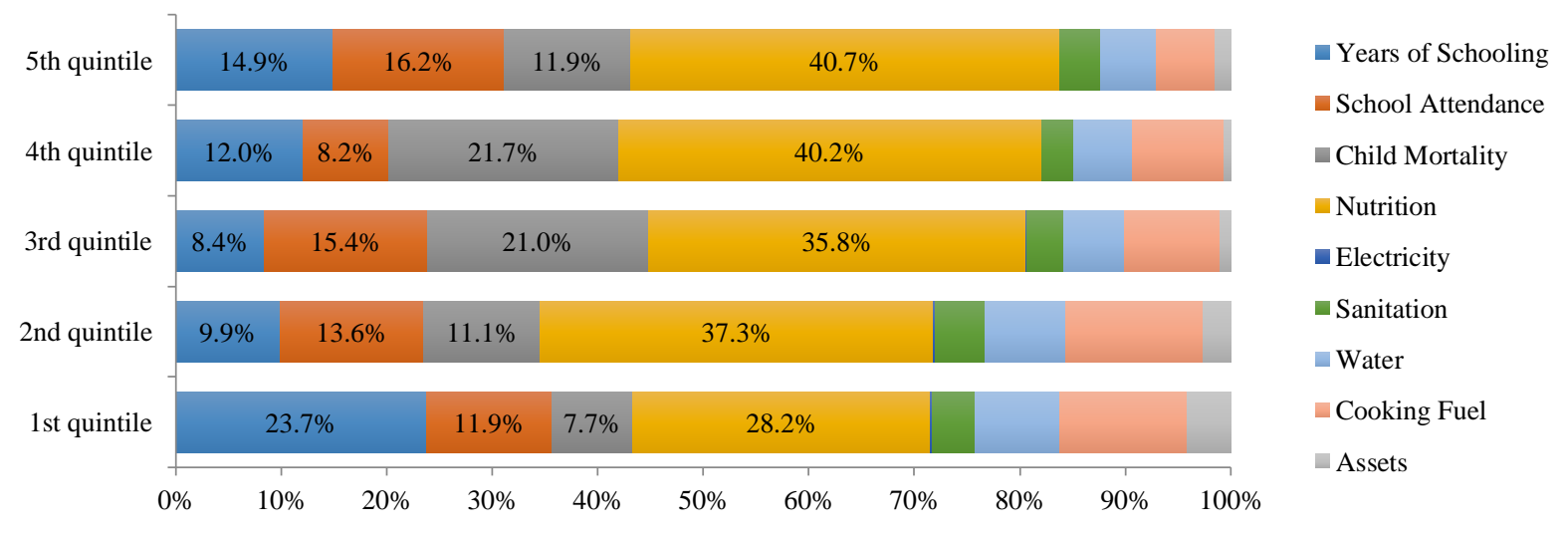

Another insight comes from considering government transfers. ${ }^{43}$ People who receive subsidies are supposed to be the poorest. So, we again expect that most multidimensionally poor people would receive subsidies. However, this is not the case. True, the $\mathrm{H}$ value in the group receiving government transfers is much higher (see Figure 6-2), but, considering the population share, actually only a small proportion of MPI poor people are, at the same time, receiving government transfers. In other

\footnotetext{
42 This is also true when we consider destitution and severe poverty.

43 Based on the CFPS questionnaire, transfer payment categories include the following: 1. minimum living allowance (Dibao); 2. reforestation subsidy (Tuigeng huanlin); 3. agricultural subsidy; 4.Wubaohu subsidy (targeted at low-income, blind, disabled, elderly, and youth who cannot support themselves); 5. Tekunhu subsidy (targeted at very poor families); 6.work injury subsidies to the linear relatives; 7. emergency or disaster relief (including material goods); 8 . other; and 9. none of the above. We define 1, 4, 5, 6, and 7 as being in the 'receives subsidy' group.
} 
words, less than 30\% (depending on the year) of the multidimensionally poor population are receiving subsidies. ${ }^{44}$ Again, it shows that people who are multidimensionally poor do not always belong to the targeted monetary poor group and that taking multidimensional poverty into account might improve the targeting of certain subsidies. In terms of the percentage contributions, the results suggest only years of schooling and nutrition have different relative contributions between the two groups. We find that nutrition has a relatively larger contribution to overall poverty for the poor who receive subsidies, while years of schooling has a relatively larger contribution for the poor who are not receiving subsidies (see Figure 6-3).

Figure 6-2 Incidence of MPI (H) by Quintiles and Subsidy Groups

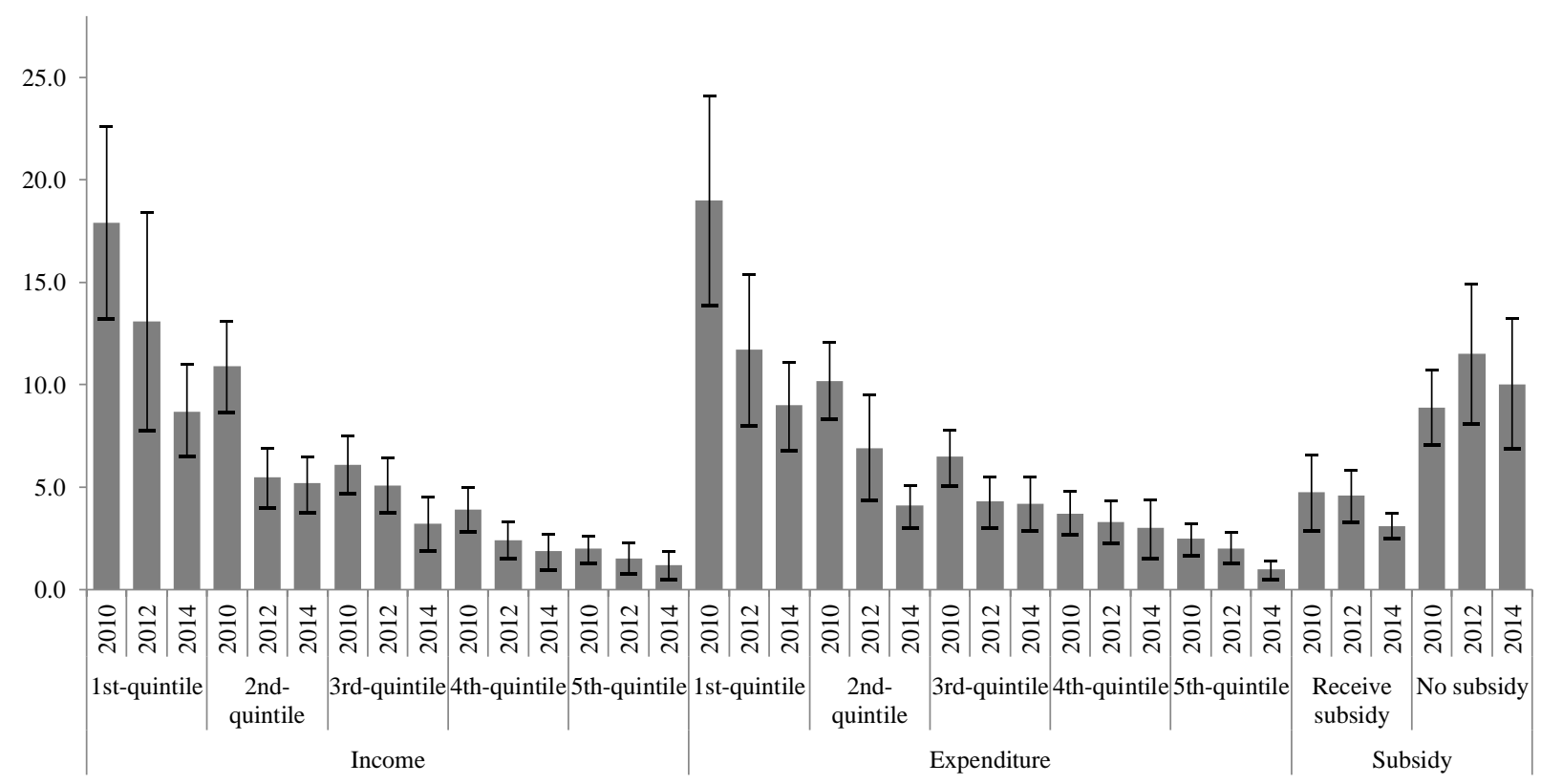

Figure 6-3 Relative Contributions for Subsidy Receiving/Not Receiving Subgroups

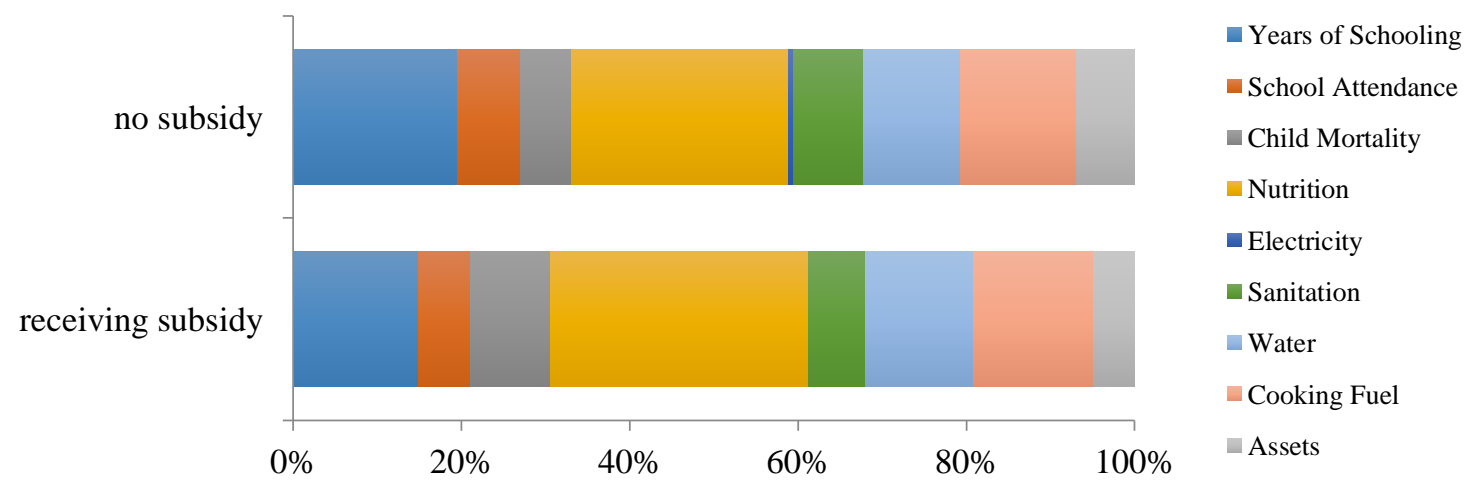

44 'Dibao' is supposed to focus on those whose disposable income is lower than a certain amount, aiming to guarantee a subsistence life for the poor. 
In general, we find a striking mismatch between monetary and multidimensional poverty. How do we explain this? On the one hand, it makes sense because non-monetary dimensions may reflect anti-poverty policies focused on infrastructure and social services, while monetary poverty decreases may reflect remittances, cash transfers, and economic activities. On the other hand, some cases also reflect someone's unsustainable decision to chase money at the cost of sacrificing their (or even the next generation's) education or health. In this sense, for the people who are both MPI and income poor, they are in a very severe situation because they lack both income and basic capabilities. If they do not belong to areas that are targeted for special interventions, it will be very difficult for them to exit poverty. ${ }^{45}$

\section{Robustness of MPI to Different Weights}

We use three additional weighting structures to do the robustness checks. In each, one dimension is iteratively weighted at one half and the other two at one quarter, and nested indicator weights are adjusted accordingly.

Table 7.1: The Original Weighting Vector and Three Additional Weighting Vectors

\begin{tabular}{|c|c|c|c|c|c|c|c|c|c|}
\hline \multirow{3}{*}{\begin{tabular}{|l|} 
Education \\
\end{tabular}} & \multirow{3}{*}{$\begin{array}{l}\text { Years of schooling } \\
\text { School attendance }\end{array}$} & \multicolumn{2}{|l|}{$\mathrm{W}-0$} & \multicolumn{2}{|l|}{ W-1 } & \multicolumn{2}{|l|}{$\mathrm{W}-2$} & \multicolumn{2}{|l|}{ W-3 } \\
\hline & & \multirow[t]{2}{*}{$1 / 3$} & $1 / 6$ & \multirow[t]{2}{*}{$1 / 2$} & $1 / 4$ & \multirow[t]{2}{*}{$1 / 4$} & $1 / 8$ & \multirow[t]{2}{*}{$1 / 4$} & $1 / 8$ \\
\hline & & & $1 / 6$ & & $1 / 4$ & & $1 / 8$ & & $1 / 8$ \\
\hline \multirow[t]{2}{*}{ Health } & Child mortality & \multirow[t]{2}{*}{$1 / 3$} & $1 / 6$ & \multirow[t]{2}{*}{$1 / 4$} & $1 / 8$ & \multirow[t]{2}{*}{$1 / 2$} & $1 / 4$ & \multirow[t]{2}{*}{$1 / 4$} & $1 / 8$ \\
\hline & Nutrition & & $1 / 6$ & & $1 / 8$ & & $1 / 4$ & & $1 / 8$ \\
\hline \multirow{5}{*}{$\begin{array}{l}\text { Living } \\
\text { Standard }\end{array}$} & Electricity & \multirow[t]{5}{*}{$1 / 3$} & $1 / 15$ & \multirow[t]{5}{*}{$1 / 4$} & $1 / 20$ & \multirow[t]{5}{*}{$1 / 4$} & $1 / 20$ & \multirow[t]{5}{*}{$1 / 2$} & $1 / 10$ \\
\hline & Improved sanitation & & $1 / 15$ & & $1 / 20$ & & $1 / 20$ & & $1 / 10$ \\
\hline & Improved drinking water & & $1 / 15$ & & $1 / 20$ & & $1 / 20$ & & $1 / 10$ \\
\hline & Cooking fuel & & $1 / 15$ & & $1 / 20$ & & $1 / 20$ & & $1 / 10$ \\
\hline & Assets ownership & & $1 / 15$ & & $1 / 20$ & & $1 / 20$ & & $1 / 10$ \\
\hline
\end{tabular}

What we wish to assess using different weighting vectors is whether the level of MPI and the ranking of MPI by subgroups or time periods will change. Three approaches to assessing the robustness to weights have been articulated elsewhere: (1) hypothesis testing with analytical distribution; (2) testing the significance of pairwise comparisons using analytical standard errors; and (3) testing the significance of pairwise comparisons using confidence intervals (Alkire et al., 2015; cf. Alkire and Santos, 2014). Given that the sample cannot be disaggregated by many subgroups, we do not implement approach (2), but rather (1) and (3).

Using analytical standard errors we find that the national estimations of MPI and $\mathrm{H}$ are not significantly different from one another for the original weighting structure or for W1 and W3,

\footnotetext{
45 We find more than 60\% of people who are deprived in both income and MPI reside in Sichuan, Guizhou, Yunnan, Sanxi, and Gansu.
} 
which reweight education and living standards at 50\%. However the estimations of MPI and $\mathrm{H}$ using W2 are significantly higher than the others. The reason, as specified earlier, is the issues related to self-reporting in the nutrition variable, which means that many non-MPI poor people are also apparently undernourished, but this may be due to non-sampling measurement error. Hence these results cannot be conclusive as to the robustness of the MPI to changes in health unless data quality issues are resolved. The robustness of MPI to weights on the health dimension needs to be assessed using a data source with anthropometric nutrition indicators.

The bootstrapped results and kernel density analysis verify this pattern. In theory, bootstrap process can obtain a consistent distribution, bootstrap distribution, with observed distribution, which equals the desired distribution of population if the sample is reprehensive with three ways (Efron, 1979). In this paper we choose the Monte Carlo approximation, which was also used for the global MPI (Alkire and Santos, 2014). To obtain the bootstrap distribution, we resample the CFPS data randomly with replacement. The bootstrap sample size is the same as the observed samples, but some individuals are replacements. The MPI estimators are calculated using the bootstrap sample; the resampling is replicated 1000 times. We compare our bootstrap MPI estimators for the four weighting structures, assessing whether the level or ranking of MPI/H within different subgroups is similar under different weighting structures and across time periods. Of course, under this estimation, the MPI/H/A we estimated is not one number but a statistical distribution. Relatively, we are able to estimate the $95 \%$ confidence interval, meaning the range of the MPI series values. Figure 7-1 shows the bootstrap results of MPI under different weighting structures from 2010-2014. Confidence intervals, added within each distribution plot, are represented by the dark areas. We use the kernel density method to draw the figure below. ${ }^{46}$

We emphasize three findings. First, from 2010-2012, we observe highly overlapping MPI results under the W0, W1, and W3 weight structures. In 2014, although the distributions are distinct, the absolute values are very close, and in 2014 the MPI values are already quite low. This suggests, as before, that MPI results are robust to a plausible range of weights across education and living standards.

Second, in 2010, distribution W3 is on the right-hand side of distributions W1 and W0, meaning that when we increase the weight on living standards, MPI increases. However, in 2012 and 2014 we observe the opposite results. This interesting result reminds us of the rapid improvement in living standards after 2012 (mainly because of China's national efforts focused on living standard improvement).

Third, the national estimation of MPI is not robust if we re-weight the health dimension to $50 \%$. In this case, MPI rises, as before, significantly.

\footnotetext{
46 When estimating the probability density curve, determining bandwidth is key. The bandwidth will divide MPI values into non-overlapping zones and calculate probabilities (frequencies) within each zone. By default, to choose the bandwidth of a Gaussian kernel density estimator we use a rule-of-thumb of 0.9 times the minimum of the standard deviation and the interquartile range, divided by 1.34 times the sample size, to the negative one-fifth power (= Silverman's 'rule of thumb' in Silverman [1986, p. 48, equation 3.31]) unless the quartiles coincide, in which a positive result will be guaranteed.
} 
As the detailed table shows, the findings reported earlier for $\mathrm{H}$ and $\mathrm{A}$, and for the population subgroups analyzed previously, are also robust across W0, W1, and W3 weighting vectors in all years.

Figure 7.1
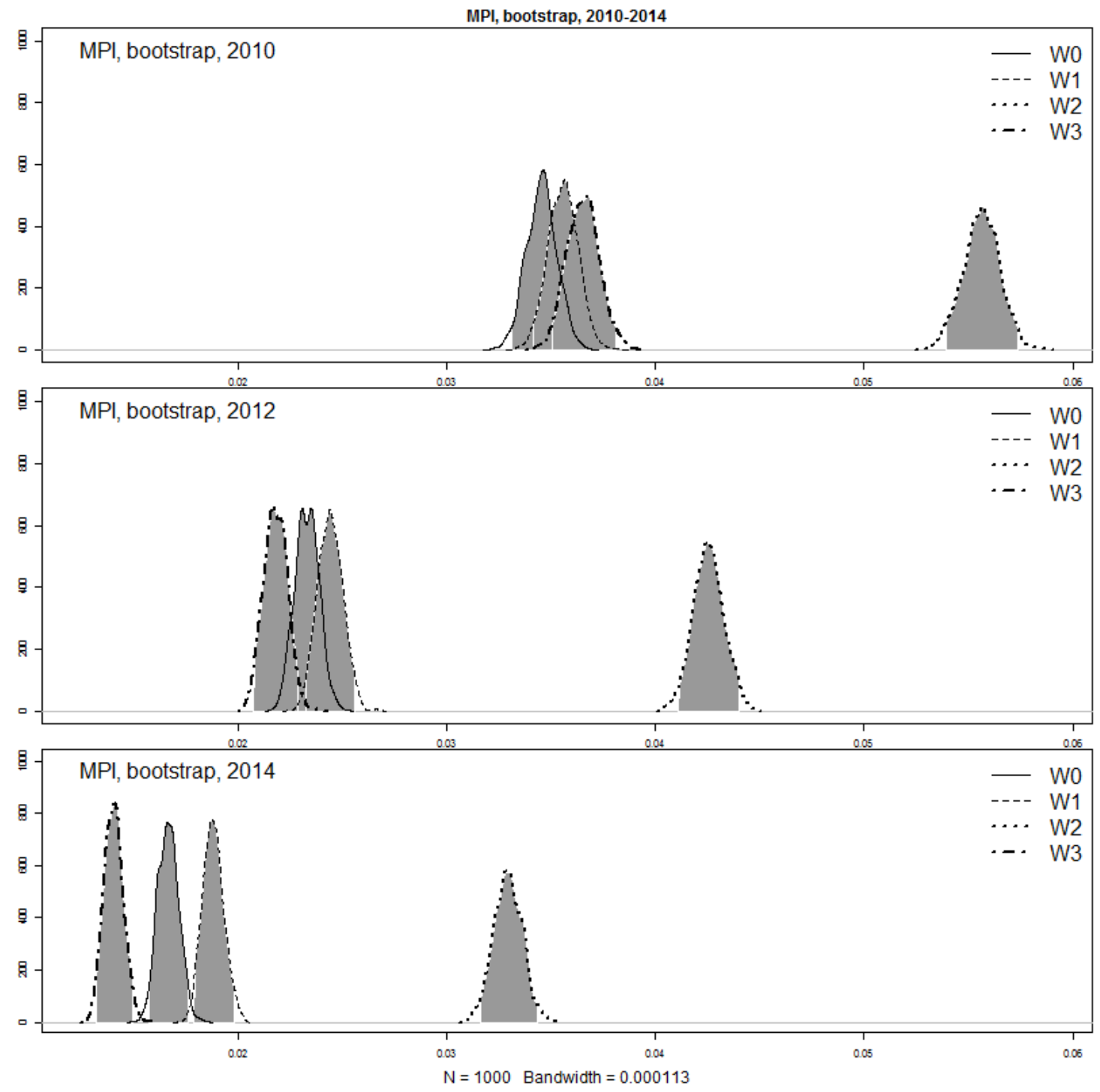
Table 7.2: The Bootstrap Confidence Intervals with Different Weights for Subgroups and Periods

\begin{tabular}{|c|c|c|c|c|c|c|c|c|c|c|}
\hline \multicolumn{4}{|l|}{2010} & \multicolumn{4}{|l|}{2012} & \multicolumn{3}{|l|}{2014} \\
\hline W0 & W1 & W2 & W3 & W0 & W1 & W2 & W3 & W0 & W1 & W2 \\
\hline$[0.033,0.036]$ & {$[0.034,0.037]$} & {$[0.054,0.057]$} & {$[0.035,0.038]$} & {$[0.022,0.024]$} & {$[0.023,0.026]$} & {$[0.041,0.044]$} & {$[0.021,0.023]$} & {$[0.016,0.018]$} & {$[0.018,0.020]$} & {$[0.032,0.034]$} \\
\hline$[0.052,0.056]$ & {$[0.054,0.058]$} & {$[0.079,0.084]$} & {$[0.057,0.062]$} & {$[0.036,0.040]$} & {$[0.038,0.042]$} & {$[0.063,0.068]$} & {$[0.035,0.039]$} & {$[0.027,0.030]$} & {$[0.029,0.033]$} & {$[0.052,0.057]$} \\
\hline$[0.013,0.015]$ & {$[0.013,0.015]$} & {$[0.026,0.030]$} & {$[0.011,0.014]$} & {$[0.008,0.010]$} & {$[0.008,0.010]$} & {$[0.019,0.022]$} & {$[0.006,0.008]$} & {$[0.006,0.008]$} & {$[0.008,0.010]$} & {$[0.014,0.017]$} \\
\hline$[0.017,0.020]$ & {$[0.019,0.022]$} & {$[0.033,0.038]$} & {$[0.015,0.018]$} & {$[0.010,0.012]$} & {$[0.012,0.014]$} & {$[0.022,0.026]$} & {$[0.008,0.010]$} & {$[0.007,0.009]$} & {$[0.009,0.012]$} & {$[0.017,0.020]$} \\
\hline$[0.022,0.026]$ & {$[0.022,0.026]$} & {$[0.049,0.054]$} & {$[0.024,0.028]$} & {$[0.013,0.016]$} & {$[0.014,0.017]$} & {$[0.039,0.044]$} & {$[0.013,0.016]$} & {$[0.012,0.015]$} & {$[0.012,0.015]$} & {$[0.031,0.035]$} \\
\hline$[0.065,0.072]$ & {$[0.066,0.074]$} & {$[0.083,0.091]$} & {$[0.072,0.080]$} & {$[0.049,0.056]$} & {$[0.049,0.056]$} & {$[0.068,0.076]$} & {$[0.047,0.054]$} & {$[0.031,0.037]$} & {$[0.035,0.040]$} & {$[0.051,0.058]$} \\
\hline$[0.028,0.033]$ & {$[0.033,0.039]$} & {$[0.040,0.046]$} & {$[0.029,0.035]$} & {$[0.019,0.023]$} & {$[0.020,0.025]$} & {$[0.034,0.039]$} & {$[0.017,0.021]$} & {$[0.013,0.017]$} & {$[0.016,0.020]$} & {$[0.024,0.029]$} \\
\hline$[0.034,0.038]$ & {$[0.034,0.037]$} & {$[0.058,0.062]$} & {$[0.036,0.040]$} & {$[0.023,0.025]$} & {$[0.024,0.026]$} & {$[0.043,0.046]$} & {$[0.021,0.024]$} & {$[0.016,0.019]$} & {$[0.018,0.021]$} & {$[0.034,0.037]$} \\
\hline$[0.038,0.064]$ & {$[0.049,0.079]$} & {$[0.038,0.063]$} & {$[0.043,0.071]$} & {$[0.019,0.035]$} & {$[0.026,0.045]$} & {$[0.035,0.058]$} & {$[0.021,0.038]$} & {$[0.013,0.024]$} & {$[0.018,0.030]$} & {$[0.025,0.040]$} \\
\hline$[0.031,0.034]$ & {$[0.031,0.034]$} & {$[0.053,0.057]$} & {$[0.033,0.035]$} & {$[0.021,0.023]$} & {$[0.022,0.024]$} & {$[0.041,0.044]$} & {$[0.019,0.022]$} & {$[0.015,0.017]$} & {$[0.016,0.018]$} & {$[0.031,0.034]$} \\
\hline$[0.057,0.074]$ & {$[0.072,0.088]$} & {$[0.055,0.071]$} & {$[0.061,0.079]$} & {$[0.034,0.046]$} & {$[0.038,0.051]$} & {$[0.042,0.055]$} & {$[0.034,0.047]$} & {$[0.026,0.036]$} & {$[0.035,0.046]$} & {$[0.033,0.043]$} \\
\hline
\end{tabular}




\begin{tabular}{|c|c|c|c|c|c|c|c|c|c|c|}
\hline$[0.099,0.109]$ & {$[0.132,0.143]$} & {$[0.089,0.098]$} & {$[0.107,0.118]$} & {$[0.072,0.082]$} & {$[0.087,0.098]$} & {$[0.081,0.091]$} & {$[0.073,0.084]$} & {$[0.053,0.062]$} & {$[0.072,0.081]$} & {$[0.070,0.079]$} \\
\hline$[0.035,0.040]$ & {$[0.029,0.033]$} & {$[0.072,0.079]$} & {$[0.036,0.042]$} & {$[0.020,0.023]$} & {$[0.020,0.023]$} & {$[0.046,0.052]$} & {$[0.018,0.022]$} & {$[0.013,0.016]$} & {$[0.013,0.016]$} & {$[0.035,0.040]$} \\
\hline$[0.011,0.015]$ & {$[0.005,0.007]$} & {$[0.037,0.042]$} & {$[0.012,0.016]$} & {$[0.006,0.008]$} & {$[0.003,0.005]$} & {$[0.024,0.029]$} & {$[0.004,0.006]$} & {$[0.006,0.009]$} & {$[0.004,0.006]$} & {$[0.022,0.026]$} \\
\hline$[0.005,0.007]$ & {$[0.002,0.004]$} & {$[0.021,0.026]$} & {$[0.004,0.006]$} & {$[0.005,0.008]$} & {$[0.003,0.006]$} & {$[0.019,0.024]$} & {$[0.003,0.005]$} & {$[0.002,0.004]$} & {$[0.002,0.003]$} & {$[0.009,0.012]$} \\
\hline$[0.033,0.040]$ & {$[0.029,0.036]$} & {$[0.051,0.060]$} & {$[0.036,0.044]$} & {$[0.028,0.036]$} & {$[0.026,0.034]$} & {$[0.042,0.050]$} & {$[0.025,0.032]$} & {$[0.016,0.021]$} & {$[0.019,0.025]$} & {$[0.024,0.031]$} \\
\hline$[0.026,0.029]$ & {$[0.027,0.030]$} & {$[0.050,0.054]$} & {$[0.028,0.031]$} & {$[0.017,0.019]$} & {$[0.016,0.019]$} & {$[0.039,0.042]$} & {$[0.015,0.017]$} & {$[0.012,0.014]$} & {$[0.012,0.014]$} & {$[0.028,0.031]$} \\
\hline$[0.055,0.064]$ & {$[0.063,0.072]$} & {$[0.066,0.075]$} & {$[0.058,0.067]$} & {$[0.036,0.042]$} & {$[0.044,0.051]$} & {$[0.045,0.052]$} & {$[0.035,0.042]$} & {$[0.027,0.032]$} & {$[0.034,0.040]$} & {$[0.045,0.052]$} \\
\hline$[0.043,0.047]$ & {$[0.045,0.049]$} & {$[0.069,0.073]$} & {$[0.047,0.051]$} & {$[0.029,0.032]$} & {$[0.031,0.034]$} & {$[0.052,0.056]$} & {$[0.028,0.031]$} & {$[0.020,0.022]$} & {$[0.023,0.025]$} & {$[0.040,0.043]$} \\
\hline$[0.006,0.008]$ & {$[0.005,0.007]$} & {$[0.013,0.017]$} & {$[0.004,0.006]$} & {$[0.005,0.007]$} & {$[0.004,0.006]$} & {$[0.013,0.016]$} & {$[0.002,0.003]$} & {$[0.004,0.007]$} & {$[0.004,0.006]$} & {$[0.010,0.013]$} \\
\hline$[0.021,0.025]$ & {$[0.022,0.027]$} & {$[0.042,0.049]$} & {$[0.019,0.024]$} & {$[0.011,0.015]$} & {$[0.013,0.016]$} & {$[0.027,0.032]$} & {$[0.010,0.013]$} & {$[0.009,0.012]$} & {$[0.011,0.015]$} & {$[0.020,0.025]$} \\
\hline$[0.048,0.055]$ & {$[0.049,0.057]$} & {$[0.084,0.093]$} & {$[0.051,0.059]$} & {$[0.031,0.037]$} & {$[0.027,0.033]$} & {$[0.070,0.078]$} & {$[0.029,0.035]$} & {$[0.025,0.032]$} & {$[0.025,0.031]$} & {$[0.055,0.063]$} \\
\hline$[0.053,0.059]$ & {$[0.055,0.061]$} & {$[0.075,0.081]$} & {$[0.059,0.066]$} & {$[0.038,0.043]$} & {$[0.043,0.049]$} & {$[0.057,0.063]$} & {$[0.038,0.043]$} & {$[0.025,0.029]$} & {$[0.030,0.035]$} & {$[0.047,0.053]$} \\
\hline$[0.004,0.006]$ & {$[0.003,0.005]$} & {$[0.010,0.013]$} & {$[0.003,0.004]$} & {$[0.004,0.006]$} & {$[0.004,0.007]$} & {$[0.009,0.013]$} & {$[0.002,0.003]$} & {$[0.004,0.007]$} & {$[0.004,0.006]$} & {$[0.009,0.012]$} \\
\hline$[0.033,0.038]$ & {$[0.054,0.061]$} & {$[0.024,0.029]$} & {$[0.037,0.043]$} & {$[0.021,0.026]$} & {$[0.039,0.047]$} & {$[0.018,0.023]$} & {$[0.022,0.028]$} & {$[0.014,0.018]$} & {$[0.028,0.033]$} & {$[0.014,0.018]$} \\
\hline
\end{tabular}




\begin{tabular}{|c|c|c|c|c|c|c|c|c|c|c|}
\hline$[0.017,0.021]$ & {$[0.018,0.022]$} & {$[0.034,0.040]$} & {$[0.017,0.021]$} & {$[0.008,0.011]$} & {$[0.008,0.011]$} & {$[0.019,0.023]$} & {$[0.006,0.009]$} & {$[0.006,0.008]$} & {$[0.007,0.009]$} & {$[0.015,0.019]$} \\
\hline$[0.028,0.034]$ & {$[0.026,0.032]$} & {$[0.060,0.067]$} & {$[0.029,0.035]$} & {$[0.018,0.023]$} & {$[0.017,0.021]$} & {$[0.040,0.046]$} & {$[0.016,0.021]$} & {$[0.009,0.012]$} & {$[0.009,0.013]$} & {$[0.021,0.026]$} \\
\hline$[0.037,0.044]$ & {$[0.027,0.033]$} & {$[0.071,0.081]$} & {$[0.036,0.044]$} & {$[0.018,0.023]$} & {$[0.016,0.021]$} & {$[0.046,0.053]$} & {$[0.017,0.022]$} & {$[0.014,0.019]$} & {$[0.015,0.020]$} & {$[0.036,0.043]$} \\
\hline$[0.061,0.073]$ & {$[0.040,0.050]$} & {$[0.109,0.123]$} & {$[0.068,0.080]$} & {$[0.044,0.051]$} & {$[0.036,0.043]$} & {$[0.080,0.089]$} & {$[0.040,0.047]$} & {$[0.032,0.039]$} & {$[0.027,0.033]$} & {$[0.066,0.075]$} \\
\hline$[0.074,0.083]$ & {$[0.077,0.086]$} & {$[0.100,0.110]$} & {$[0.083,0.093]$} & {$[0.057,0.065]$} & {$[0.065,0.074]$} & {$[0.068,0.077]$} & {$[0.057,0.065]$} & {$[0.034,0.040]$} & {$[0.046,0.054]$} & {$[0.055,0.062]$} \\
\hline$[0.041,0.048]$ & {$[0.039,0.045]$} & {$[0.070,0.078]$} & {$[0.043,0.050]$} & {$[0.020,0.025]$} & {$[0.023,0.027]$} & {$[0.046,0.053]$} & {$[0.018,0.023]$} & {$[0.019,0.024]$} & {$[0.019,0.023]$} & {$[0.045,0.051]$} \\
\hline$[0.024,0.029]$ & {$[0.022,0.027]$} & {$[0.049,0.056]$} & {$[0.023,0.029]$} & {$[0.018,0.023]$} & {$[0.015,0.019]$} & {$[0.049,0.056]$} & {$[0.016,0.020]$} & {$[0.011,0.015]$} & {$[0.012,0.015]$} & {$[0.028,0.033]$} \\
\hline$[0.014,0.018]$ & {$[0.016,0.020]$} & {$[0.029,0.035]$} & {$[0.013,0.018]$} & {$[0.008,0.011]$} & {$[0.008,0.011]$} & {$[0.024,0.029]$} & {$[0.007,0.010]$} & {$[0.006,0.009]$} & {$[0.004,0.006]$} & {$[0.016,0.021]$} \\
\hline$[0.006,0.009]$ & {$[0.011,0.014]$} & {$[0.015,0.019]$} & {$[0.006,0.009]$} & {$[0.005,0.007]$} & {$[0.004,0.007]$} & {$[0.013,0.018]$} & {$[0.003,0.005]$} & {$[0.004,0.006]$} & {$[0.004,0.006]$} & {$[0.008,0.011]$} \\
\hline
\end{tabular}




\section{Concluding Remarks}

Using the AF methodology with the global MPI standard, we find China's global MPI value is low and has kept falling over time. Although the incidence of multidimensional poverty is not high, it still affects millions of people.

In terms of who is poor, some findings confirm what we would expect: rural areas are poorer than urban areas, and the West region is poorer that the Central and East regions. This implies that the imbalance in regional development affects poverty. But, in the meantime, the poverty ranking for the 'large provinces' tells us that economic growth does not necessarily go together with multidimensional poverty reduction.

In terms of household characteristics, households that have household heads with higher levels of education, are smaller in size, or that have migrated are often associated with lower multidimensional poverty. Households that have household heads who are divorced or widowed, have members that belong to minority ethnic groups, or hold a rural hukou are often associated with a higher likelihood of poverty.

In terms of the ways in which people are poor at the national level, we have found nutrition, years of schooling, cooking fuel and safe drinking water are the main contributors to MPI. But these percentage contributions vary according to area and depend on household characteristics. The MPI thus can play a very useful role in guiding efficient integrated and multisectoral policy design and planning.

Last, and most surprisingly, we found a striking mismatch between households suffering from monetary and multidimensional poverty, suggesting that monetary measures do not tell the whole story of poverty. The importance of using multidimensional poverty methods to evaluate, target, and design policies to fight multidimensional poverty is worthy of attention. 


\section{Appendices}

\section{Appendix A: China's Rural Official Poverty Line and Rural Poverty: 1980-2014}

\begin{tabular}{|c|c|c|c|}
\hline Year & Official Poverty Line (yuan) & Headcount Ratio (\%) & Poverty People (10thousand) \\
\hline 1980 & 130 & 26.8 & 22000 \\
\hline 1985 & 206 & 14.8 & 12500 \\
\hline 1990 & 300 & 9.4 & 8500 \\
\hline 1995 & 530 & 7.1 & 6500 \\
\hline 2000 & 625 & 3.5 & 3209 \\
\hline 2001 & 630 & 3.2 & 2927 \\
\hline 2002 & 627 & 3 & 2820 \\
\hline 2003 & 637 & 3.1 & 2900 \\
\hline 2004 & 668 & 2.8 & 2610 \\
\hline 2005 & 683 & 2.5 & 2360 \\
\hline 2006 & 693 & 2.3 & 2148 \\
\hline 2007 & 785 & 1.6 & 1479 \\
\hline 2008 & 1196 & 4.2 & 4007 \\
\hline 2009 & 1196 & 3.8 & 3597 \\
\hline 2010 & 1247 & 2.8 & 2688 \\
\hline 2010 (new) & 2300 & 17.2 & 16567 \\
\hline 2011 & 2536 & 13.8 & 12238 \\
\hline 2012 & 2673 & 10.2 & 9899 \\
\hline 2013 & 2736 & 8.6 & 8249 \\
\hline 2014 & 2800 & 7.2 & 7017 \\
\hline 2015 & 2855 & 5.7 & 5575 \\
\hline
\end{tabular}

Note: a. In 2008, China used a 'low income poverty line' to replace the previous extreme poverty line. The official poverty standard increased, so rural poverty increased. 
b. At the end of 2011, China adjusted and increased the rural poverty line again. The rural poverty line increased to 2300 yuan (2011 constant price), so rural poverty increased correspondingly.

Source: China Rural Household Survey Yearbook, 1980-2010 [in Chinese]; China Housebold Survey Yearbook, $2011-2014$ [in Chinese]; Statistical Communiqué of the People's Republic of China on the 2014 National Economy

\section{Appendix B: Nutrition (BMI) Distribution among Ages for Adults}

\begin{tabular}{lll}
\hline \hline $\begin{array}{l}\text { Age } \\
\text { Group }\end{array}$ & Population Share $(\%)$ & $\begin{array}{l}\text { Percentage of Malnourished } \\
(\mathrm{bmi}<18.5)\end{array}$ \\
\hline$[15,19)$ & 7.37 & 0.29 \\
{$[19,30)$} & 20.1 & 0.12 \\
{$[30,40)$} & 16.4 & 0.06 \\
{$[40,50)$} & 21.7 & 0.05 \\
{$[50,60)$} & 16.3 & 0.07 \\
{$[60,70)$} & 11.5 & 0.12 \\
{$[70,80)$} & 5.40 & 0.18 \\
{$[80,90)$} & 1.20 & 0.23 \\
{$[90,90+]$} & 0.07 & 0.41 \\
\hline \hline
\end{tabular}

Source: $\overline{\overline{C F P S}-2012 .}$

\section{Appendix C: Extreme Indicators of Destitution Poverty and Deprivation Thresholds}

\begin{tabular}{|c|c|c|c|c|}
\hline Dimension & Indicator & Deprived if... & $\begin{array}{l}\text { Related } \\
\text { to... }\end{array}$ & Weight \\
\hline \multirow{3}{*}{ Education } & Years of schooling & $\begin{array}{l}\text { No household member has completed at least one year of schooling } \\
(>=1) .\end{array}$ & MDG2 & $1 / 6$ \\
\hline & & & & \\
\hline & $\begin{array}{l}\text { Child School } \\
\text { Attendance }\end{array}$ & $\begin{array}{l}\text { No child is attending school up to the age at which they should finish } \\
\text { class } 6 .\end{array}$ & MDG2 & $1 / 6$ \\
\hline \multirow[b]{2}{*}{ Health } & Child Mortality & Two or more children have died in the household. & MDG4 & $1 / 6$ \\
\hline & Nutrition & $\begin{array}{l}\text { Severe undernourishment of any adult }\left(\mathrm{BMI}<17 \mathrm{~kg} / \mathrm{m}^{2}\right) \text { or any child }(-3 \\
\text { standard deviations from the median). }\end{array}$ & MDG1 & $1 / 6$ \\
\hline \multirow{4}{*}{$\begin{array}{l}\text { Living } \\
\text { Standard }\end{array}$} & Electricity & The household has no electricity (no change). & & $1 / 15$ \\
\hline & Improved Sanitation & There is no facility (open defecation). & MDG7 & $1 / 15$ \\
\hline & Safe Drinking Water & The household does not have access to safe drinking water. & MDG7 & $1 / 15$ \\
\hline & Cooking Fuel & The household cooks with dung or wood (coal/lignite/charcoal are now & MDG7 & $1 / 15$ \\
\hline
\end{tabular}


Source: http://www.ophi.org.uk/wp-content/uploads/Poverty-in-China-2015_digital.pdf.

\section{Appendix D: Poverty Comparison: Gender Differences under Different Marriage Statuses}

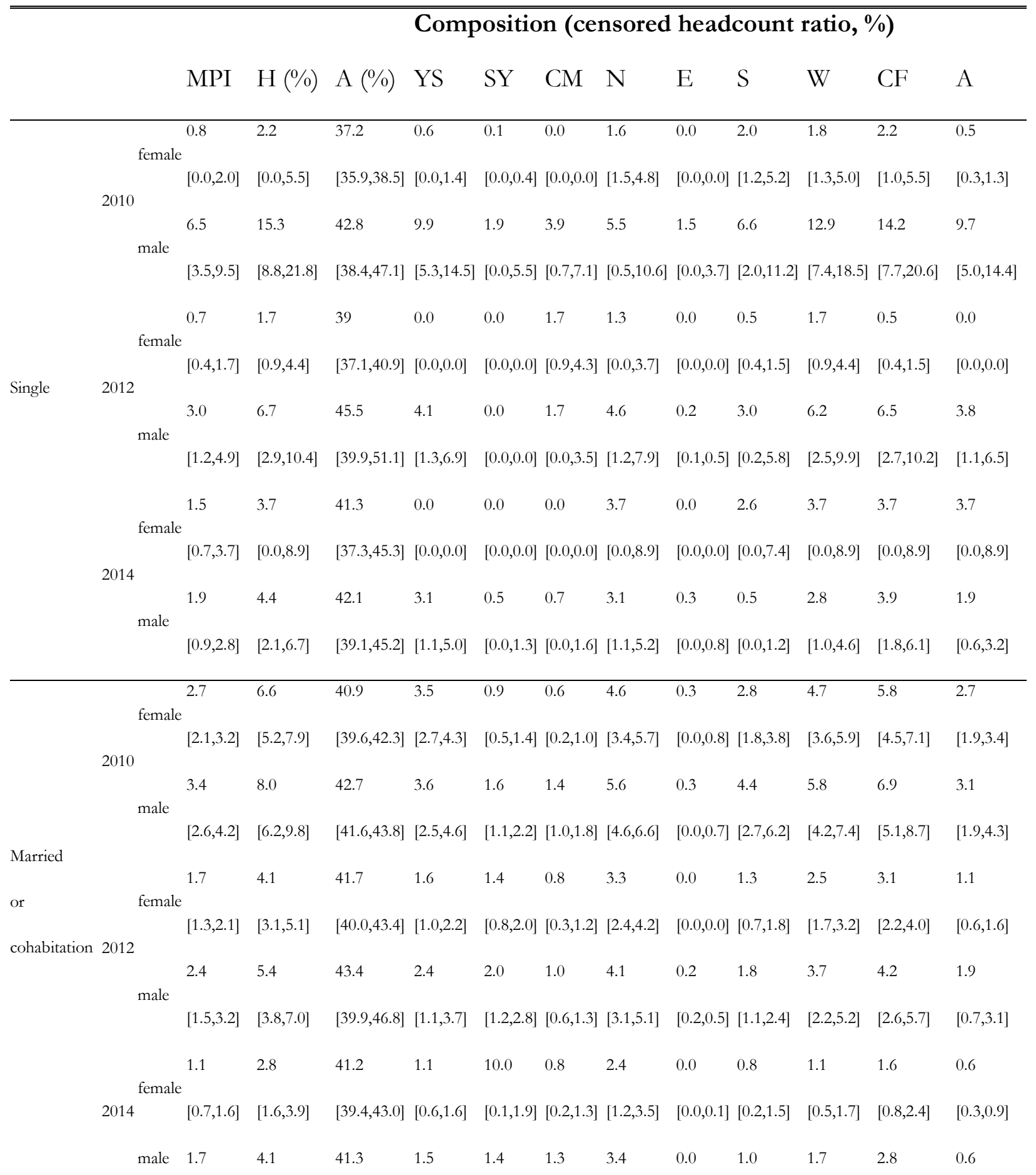




\begin{tabular}{|c|c|c|c|c|c|c|c|c|c|c|c|c|c|c|}
\hline & & & {$[1.3,2.1]$} & {$[3.2,5.0]$} & {$[39.8,42.8]$} & {$[0.9,2.1]$} & {$[0.9,2.0]$} & {$[0.9,1.7]$} & {$[2.7,4.2]$} & {$[0.0,0.1]$} & {$[0.5,1.4]$} & {$[1.3,2.2]$} & {$[2.1,3.6]$} & {$[0.3,0.9]$} \\
\hline & & & 5.8 & 13.5 & 43.0 & 10.1 & 2.0 & 1.4 & 6.7 & 0.0 & 5.2 & 11.1 & 11.9 & 8.6 \\
\hline & & female & & & & & & & & & & & & \\
\hline & & & {$[4.3,7.3]$} & {$[10.2,16.9]$} & {$[40.6,45.4]$} & {$[7.3,12.9]$} & {$[0.6,3.5]$} & {$[0.0,2.8]$} & {$[4.2,9.1]$} & {$[0.0,0.0]$} & {$[2.9,7.4]$} & {$[7.9,14.3]$} & {$[8.8,15.0]$} & {$[5.9,11.2]$} \\
\hline & 2010 & & & & & & & & & & & & & \\
\hline & & & 7.7 & 18.3 & 42.0 & 7.4 & 4.2 & 3.8 & 9.6 & 0.9 & 9.4 & 14.8 & 17.3 & 10.4 \\
\hline & & male & & & & & & & & & & & & \\
\hline & & & {$[5.0,10.4]$} & {$[12.2,24.5]$} & {$[39.8,44.3]$} & {$[4.6,10.2]$} & {$[0.2,8.2]$} & {$[0.0,7.9]$} & {$[4.6,14.6]$} & {$[0.7,2.5]$} & {$[3.7,15.2]$} & {$[9.4,20.2]$} & {$[11.2,23.5]$} & {$[6.3,14.4]$} \\
\hline & & & 4.1 & 10.0 & 40.9 & 5.7 & 1.7 & 1.9 & 6.2 & 0.0 & 3.4 & 6.5 & 8.1 & 4.9 \\
\hline \multirow[t]{2}{*}{ Divorced } & & female & & & & & & & & & & & & \\
\hline & & & {$[2.7,5.5]$} & {$[7.0,13.1]$} & {$[37.4,44.4]$} & {$[3.5,7.9]$} & {$[0.2,3.1]$} & {$[0.4,3.4]$} & {$[3.7,8.7]$} & {$[0.0,0.0]$} & {$[1.4,5.4]$} & {$[3.8,9.2]$} & {$[5.3,11.0]$} & {$[2.7,7.0]$} \\
\hline \multirow[t]{2}{*}{ or } & 2012 & & & & & & & & & & & & & \\
\hline & & & 3.8 & 8.8 & 43.3 & 5.1 & 1.6 & 2.0 & 4.4 & 0.6 & 1.9 & 6.8 & 8.0 & 7.3 \\
\hline \multirow[t]{9}{*}{ widowed } & & male & & & & & & & & & & & & \\
\hline & & & {$[2.0,5.7]$} & {$[4.8,12.9]$} & {$[39.1,47.6]$} & {$[2.1,8.0]$} & {$[0.0,3.9]$} & {$[0.2,3.9]$} & {$[1.4,7.4]$} & {$[0.0,1.9]$} & {$[0.2,3.6]$} & {$[3.1,10.4]$} & {$[4.0,12.0]$} & {$[3.3,11.2]$} \\
\hline & & & 3.2 & 7.7 & 41.1 & 4.7 & 1.5 & 1.3 & 5.7 & 0.0 & 1.9 & 3.9 & 6.0 & 2.5 \\
\hline & & female & & & & & & & & & & & & \\
\hline & & & {$[2.0,4.3]$} & {$[4.9,10.5]$} & {$[38.7,43.4]$} & {$[2.6,6.9]$} & {$[0.2,2.8]$} & {$[0.3,2.2]$} & {$[3.2,8.2]$} & {$[0.0,0.1]$} & {$[0.4,3.3]$} & {$[2.0,5.8]$} & {$[3.4,8.6]$} & {$[1.5,3.5]$} \\
\hline & 2014 & & & & & & & & & & & & & \\
\hline & & & 3.0 & 7.1 & 41.7 & 3.7 & 1.2 & 1.7 & 5.8 & 0.0 & 2.9 & 4.4 & 5.3 & 0.8 \\
\hline & & male & & & & & & & & & & & & \\
\hline & & & {$[1.5,4.5]$} & {$[3.6,10.6]$} & {$[38.5,45.0]$} & {$[1.1,6.2]$} & {$[0.0,2.6]$} & {$[0.4,3.1]$} & {$[2.4,9.3]$} & {$[0.0,0.0]$} & {$[0.6,5.2]$} & {$[1.3,7.6]$} & {$[2.0,8.6]$} & {$[0.2,1.4]$} \\
\hline
\end{tabular}

\section{Appendix E: Poverty Comparison: Gender Differences under Different Migration Actions}

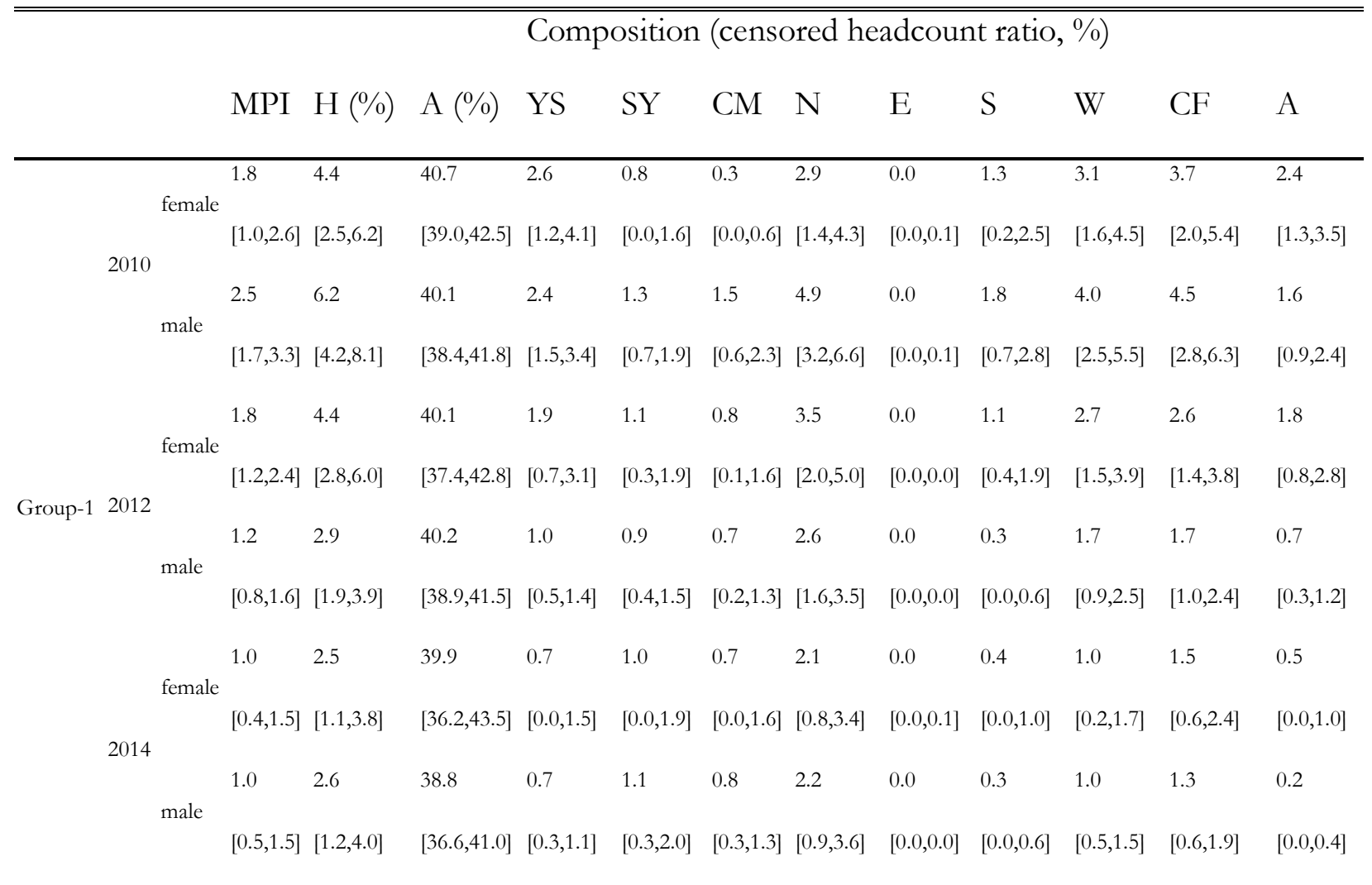




\begin{tabular}{|c|c|c|c|c|c|c|c|c|c|c|c|c|c|c|}
\hline & & & 5.5 & 12.9 & 42.5 & 8.1 & 1.9 & 0.8 & 8.9 & 0.0 & 4.5 & 11.3 & 11.7 & 5.5 \\
\hline & & female & & & & & & & & & & & & \\
\hline & & & {$[3.9,7.1]$} & {$[9.4,16.5]$} & {$[39.9,45.1]$} & {$[5.2,11.1]$} & {$[0.6,3.2]$} & {$[0.0,1.9]$} & {$[6.2,11.5]$} & {$[0.0,0.1]$} & {$[2.3,6.8]$} & {$[7.9,14.7]$} & {$[8.2,15.3]$} & {$[2.8,8.1]$} \\
\hline & 2010 & & & & & & & & & & & & & \\
\hline & & & 5 & 11.5 & 43.2 & 5.4 & 2.0 & 2.2 & 8.1 & 0.1 & 6.6 & 8.1 & 10.7 & 4.8 \\
\hline & & male & & & & & & & & & & & & \\
\hline & & & {$[3.6,6.4]$} & {$[8.5,14.5]$} & {$[41.4,45.1]$} & {$[3.5,7.4]$} & {$[0.6,3.3]$} & {$[1.1,3.2]$} & {$[5.9,10.3]$} & {$[0.1,0.3]$} & {$[3.8,9.3]$} & {$[5.9,10.4]$} & {$[7.8,13.7]$} & {$[2.6,7.1]$} \\
\hline & & & 3.8 & 8.7 & 44.3 & 3.1 & 2.9 & 2.4 & 7.3 & 0.0 & 3.9 & 4.8 & 7.6 & 1.9 \\
\hline & & female & & & & & & & & & & & & \\
\hline & & & {$[2.3,5.3]$} & {$[5.4,11.9]$} & {$[40.5,48.0]$} & {$[1.1,5.0]$} & {$[1.0,4.8]$} & {$[0.8,4.0]$} & {$[4.4,10.2]$} & {$[0.0,0.0]$} & {$[1.5,6.4]$} & {$[2.0,7.5]$} & {$[4.4,10.8]$} & {$[0.3,3.5]$} \\
\hline Group-2 & 2012 & & & & & & & & & & & & & \\
\hline & & & 3.2 & 7.2 & 44.1 & 2.2 & 3.6 & 1.9 & 5.1 & 0.0 & 2.6 & 4.7 & 5.7 & 2.9 \\
\hline & & male & & & & & & & & & & & & \\
\hline & & & {$[2.1,4.3]$} & {$[5.0,9.4]$} & {$[40.7,47.5]$} & {$[0.7,3.7]$} & {$[2.0,5.3]$} & {$[1.0,2.9]$} & {$[3.5,6.7]$} & {$[0.0,0.0]$} & {$[1.3,3.9]$} & {$[2.8,6.5]$} & {$[3.7,7.8]$} & {$[1.3,4.5]$} \\
\hline & & & 3.4 & 7.8 & 43.5 & 3.1 & 2.4 & 2.4 & 6.7 & 0.0 & 3.7 & 3.9 & 5.9 & 1.1 \\
\hline & & female & & & & & & & & & & & & \\
\hline & & & {$[1.7,5.1]$} & {$[3.9,11.8]$} & {$[40.8,46.3]$} & {$[0.9,5.3]$} & {$[0.6,4.2]$} & {$[0.0,4.9]$} & {$[3.1,10.4]$} & {$[0.0,0.0]$} & {$[0.4,6.9]$} & {$[1.5,6.4]$} & {$[2.3,9.5]$} & {$[0.1,2.0]$} \\
\hline & 2014 & & & & & & & & & & & & & \\
\hline & & & 2.7 & 6.4 & 42.3 & 1.4 & 2.3 & 2.4 & 5.5 & 0.0 & 2.4 & 2.9 & 5.3 & 1.3 \\
\hline & & male & & & & & & & & & & & & \\
\hline & & & {$[1.7,3.7]$} & {$[4.1,8.6]$} & {$[40.8,43.9]$} & {$[0.5,2.2]$} & {$[1.2,3.4]$} & {$[1.0,3.7]$} & {$[3.5,7.4]$} & {$[0.0,0.0]$} & {$[0.6,4.3]$} & {$[1.7,4.0]$} & {$[3.2,7.4]$} & {$[-0.0,2.5]$} \\
\hline & & & 6.2 & 15 & 41.5 & 8.9 & 1.7 & 1.7 & 9.0 & 1.1 & 7.0 & 10.8 & 14 & 7.2 \\
\hline & & female & & & & & & & & & & & & \\
\hline & & & {$[4.8,7.6]$} & {$[11.6,18.3]$} & {$[39.8,43.2]$} & {$[6.7,11.2]$} & {$[0.6,2.7]$} & {$[0.5,2.9]$} & {$[6.0,12.1]$} & {$[0.0,2.8]$} & {$[4.2,9.8]$} & {$[7.7,13.8]$} & {$[10.6,17.4]$} & {$[5.3,9.1]$} \\
\hline & 2010 & & 5.5 & 12.5 & 43.6 & 5.9 & 2.7 & 1.8 & 7.6 & 0.8 & 8.0 & 10.2 & 11.6 & 6.0 \\
\hline & & male & & & & & & & & & & & & \\
\hline & & & {$[3.6,7.3]$} & {$[8.6,16.4]$} & {$[42.1,45.0]$} & {$[3.9,7.9]$} & {$[1.5,3.9]$} & {$[1.1,2.6]$} & {$[5.9,9.3]$} & {$[-0.5,2.2]$} & {$[3.9,12.0]$} & {$[6.3,14.1]$} & {$[7.7,15.6]$} & {$[3.1,8.9]$} \\
\hline & & & 3.4 & 8.4 & 40.3 & 4.5 & 2.1 & 1.0 & 5.3 & 0.0 & 2.0 & 6.2 & 6.8 & 3.5 \\
\hline & & female & & & & & & & & & & & & \\
\hline & & & {$[2.3,4.4]$} & {$[5.7,11.1]$} & {$[38.6,42.0]$} & {$[2.9,6.0]$} & {$[0.7,3.6]$} & {$[0.0,2.4]$} & {$[3.0,7.5]$} & {$[0.0,0.0]$} & {$[1.0,3.0]$} & {$[4.2,8.2]$} & {$[4.6,9.1]$} & {$[1.9,5.1]$} \\
\hline Group-3 & 2012 & & & & & & & & & & & & & \\
\hline & & & 4.2 & 9.4 & 44.9 & 5.5 & 2.5 & 1.1 & 6.7 & 0.6 & 3.6 & 7.5 & 8.4 & 4.0 \\
\hline & & male & & & & & & & & & & & & \\
\hline & & & {$[2.2,6.2]$} & {$[5.7,13.2]$} & {$[40.8,48.9]$} & {$[2.4,8.6]$} & {$[0.9,4.1]$} & {$[0.5,1.7]$} & {$[4.5,8.9]$} & {$[0.0,1.7]$} & {$[2.2,5.0]$} & {$[3.8,11.2]$} & {$[4.6,12.1]$} & {$[0.9,7.2]$} \\
\hline & & & 2.1 & 5.3 & 39.5 & 4.1 & 0.4 & 0.6 & 3.5 & 0.0 & 0.7 & 2.4 & 4.1 & 2.4 \\
\hline & & female & & & & & & & & & & & & \\
\hline & & & {$[1.4,2.8]$} & {$[3.5,7.0]$} & {$[38.2,40.8]$} & {$[2.5,5.6]$} & {$[0.0,0.8]$} & {$[0.1,1.3]$} & {$[2.0,5.1]$} & {$[0.0,0.0]$} & {$[0.0,1.4]$} & {$[1.4,3.3]$} & {$[2.5,5.8]$} & {$[1.4,3.5]$} \\
\hline & 2014 & & & & & & & & & & & & & \\
\hline & & & 3.0 & 7.2 & 42.3 & 3.8 & 2.0 & 1.9 & 5.7 & 0.1 & 1.8 & 3.6 & 5.4 & 1.3 \\
\hline & & male & & & & & & & & & & & & \\
\hline & & & {$[2.1,4.0]$} & {$[5.2,9.2]$} & {$[40.2,44.5]$} & {$[2.1,5.5]$} & {$[0.8,3.3]$} & {$[1.1,2.6]$} & {$[4.0,7.3]$} & {$[0.0,0.2]$} & {$[0.8,2.7]$} & {$[2.6,4.6]$} & {$[3.6,7.1]$} & {$[0.7,1.8]$} \\
\hline & & & 0.6 & 1.6 & 37.9 & 0.5 & 0.4 & 0.3 & 1.2 & 0.0 & 1.0 & 0.8 & 0.9 & 0.5 \\
\hline & & female & & & & & & & & & & & & \\
\hline & & & {$[0.2,1.0]$} & {$[0.6,2.6]$} & {$[35.0,40.8]$} & {$[0.1,0.9]$} & {$[-0.1,0.9]$} & {$[0.0,0.8]$} & {$[0.4,2.1]$} & {$[0.0,0.0]$} & {$[0.1,1.8]$} & {$[0.1,1.5]$} & {$[0.1,1.7]$} & {$[0.1,0.9]$} \\
\hline & 2010 & & 0.5 & 1.4 & 37.1 & 0.4 & 0.2 & 0.6 & 1.3 & 0.0 & 0.4 & 0.3 & 0.5 & 0.1 \\
\hline Group-3 & & male & & & & & & & & & & & & \\
\hline & & & {$[0.3,0.7]$} & {$[0.7,2.0]$} & {$[34.8,39.4]$} & {$[0.1,0.6]$} & {$[0.0,0.4]$} & {$[0.2,1.1]$} & {$[0.7,1.9]$} & {$[0.0,0.0]$} & {$[0.1,0.7]$} & {$[0.0,0.6]$} & {$[0.1,0.9]$} & {$[0.0,0.1]$} \\
\hline & & & 0.3 & 0.8 & 38.9 & 0.4 & 0.2 & 0.2 & 0.7 & 0.0 & 0.2 & 0.2 & 0.4 & 0.2 \\
\hline & $2012 \mathrm{f}$ & female & & & & & & & & & & & & \\
\hline & & & {$[0.1,0.6]$} & {$[0.2,1.5]$} & {$[33.9,43.8]$} & {$[0.1,0.7]$} & {$[0.0,0.6]$} & {$[0.0,0.6]$} & {$[0.2,1.2]$} & {$[0.0,0.0]$} & {$[-0.2,0.7]$} & {$[-0.0,0.4]$} & {$[0.0,0.9]$} & {$[0.0,0.5]$} \\
\hline
\end{tabular}




\begin{tabular}{|c|c|c|c|c|c|c|c|c|c|c|c|c|c|}
\hline \multirow{2}{*}{\multicolumn{2}{|c|}{ male }} & 0.6 & 1.6 & 35.1 & 0.2 & 0.8 & 0.5 & 1.3 & 0.0 & 0.3 & 0.4 & 0.5 & 0.1 \\
\hline & & {$[0.3,0.9]$} & {$[0.8,2.5]$} & {$[33.9,36.4]$} & {$[0.1,0.4]$} & {$[0.1,1.5]$} & {$[0.0,1.0]$} & {$[0.5,2.1]$} & {$[0.0,0.0]$} & {$[0.0,0.6]$} & {$[0.1,0.7]$} & {$[0.1,0.8]$} & {$[0.0,0.2]$} \\
\hline \multirow{3}{*}{\multicolumn{2}{|c|}{ female }} & 0.8 & 1.8 & 41.8 & 0.4 & 1.0 & 0.4 & 1.7 & 0.0 & 0.7 & 0.8 & 0.5 & 0.3 \\
\hline & & & & & & & & & & & & & \\
\hline & & {$[0.0,1.5]$} & {$[0.1,3.5]$} & {$[39.4,44.2]$} & {$[0.0,0.8]$} & {$[0.0,2.7]$} & {$[0.1,0.8]$} & {$[0.0,3.5]$} & {$[0.0,0.1]$} & {$[0.0,1.7]$} & {$[0.0,1.7]$} & {$[0.0,1.2]$} & {$[0.0,0.6]$} \\
\hline \multirow{2}{*}{\multicolumn{2}{|c|}{2014}} & & & & & & & & & & & & \\
\hline & & 0.5 & 1.2 & 37.6 & 0.3 & 0.3 & 0.6 & 1.2 & 0.0 & 0.1 & 0.3 & 0.6 & 0.0 \\
\hline \multirow{2}{*}{\multicolumn{2}{|c|}{ male }} & & & & & & & & & & & & \\
\hline & & {$[0.2,0.7]$} & {$[0.6,1.9]$} & {$[35.6,39.5]$} & {$[0.1,0.6]$} & {$[0.1,0.7]$} & {$[0.1,1.1]$} & {$[0.5,1.8]$} & {$[0.0,0.1]$} & {$[0.0,0.2]$} & {$[0.0,0.6]$} & {$[0.2,1.0]$} & {$[0.0,0.1]$} \\
\hline
\end{tabular}

\section{Appendix F: National Poverty Comparisons over Time}

\begin{tabular}{|c|c|c|c|c|c|c|c|c|c|}
\hline \multirow{2}{*}{\multicolumn{2}{|c|}{$\begin{array}{ll} & \begin{array}{l}\text { Absolute } \\
\text { annualized } \\
\text { change }\end{array} \\
2010-2012\end{array}$}} & \multicolumn{2}{|c|}{$\begin{array}{l}\text { t-statistics } \\
\text { for } \\
\text { difference }\end{array}$} & \multirow{2}{*}{$\begin{array}{l}\text { Absolute } \\
\text { annualized } \\
\text { change }\end{array}$} & \multicolumn{2}{|c|}{$\begin{array}{l}\text { t-statistics } \\
\text { for } \\
\text { difference }\end{array}$} & \multirow{2}{*}{$\begin{array}{l}\begin{array}{l}\text { Absolute } \\
\text { annualized } \\
\text { change }\end{array} \\
2010-2014\end{array}$} & \multicolumn{2}{|c|}{$\begin{array}{l}\text { t-statistics } \\
\text { for } \\
\text { difference }\end{array}$} \\
\hline & & & & & & & & & \\
\hline$\overline{\mathrm{MPI}}$ & 0.006 & 2.25 & $* * *$ & 0.003 & 1.65 & & 0.005 & 4.44 & $* * *$ \\
\hline $\mathrm{H}$ & 1.4 & 2.68 & $* * *$ & 0.7 & 1.73 & $*$ & 1.0 & 4.69 & $* * *$ \\
\hline A & -0.3 & 0.41 & & 0.8 & 1.07 & & 0.3 & 1.26 & \\
\hline \multicolumn{10}{|l|}{$\overline{\mathrm{RHR}}$} \\
\hline $\begin{array}{l}\text { Years of } \\
\text { schooling }\end{array}$ & 1.4 & 3.44 & $* * *$ & 0.2 & 0.67 & & 0.8 & 4.58 & $* * *$ \\
\hline $\begin{array}{l}\text { Child School } \\
\text { Attendance }\end{array}$ & -0.3 & 1.05 & & 0.3 & 1.31 & & 0.0 & 0.35 & \\
\hline $\begin{array}{l}\text { Child } \\
\text { Mortality }\end{array}$ & 0.0 & 0.10 & & -0.1 & 0.3 & & 0.0 & .42 & \\
\hline Nutrition & -.07 & 1.20 & & 1.8 & 3.25 & $* * *$ & 0.6 & 2.12 & $* *$ \\
\hline Electricity & 0.1 & 0.77 & & 0.1 & 1.06 & & 0.1 & 1.53 & \\
\hline $\begin{array}{l}\text { Improved } \\
\text { Sanitation }\end{array}$ & 1.7 & 2.22 & ** & 2.1 & 4.13 & $* * *$ & 1.9 & 5.42 & $* * *$ \\
\hline $\begin{array}{l}\text { Safe } \\
\text { Drinking } \\
\text { Water }\end{array}$ & 2.1 & 1.61 & & 3.0 & 2.57 & $* *$ & 2.6 & 4.13 & $* * *$ \\
\hline
\end{tabular}




\begin{tabular}{|c|c|c|c|c|c|c|c|c|c|}
\hline $\begin{array}{l}\text { Cooking } \\
\text { Fuel }\end{array}$ & 2.2 & 4.83 & $* * *$ & 1.0 & 3.33 & $* * *$ & 1.6 & 8.99 & $* * *$ \\
\hline Assets & -2.0 & 4.48 & $* * *$ & -2.0 & 4.48 & $* * *$ & -2.0 & 4.48 & $* * *$ \\
\hline \multicolumn{10}{|l|}{$\overline{\mathrm{CHR}}$} \\
\hline $\begin{array}{l}\text { Years of } \\
\text { schooling }\end{array}$ & 0.8 & 2.19 & $* *$ & 0.4 & 1.33 & & 0.6 & 4.50 & $* * *$ \\
\hline $\begin{array}{l}\text { Child School } \\
\text { Attendance }\end{array}$ & -0.1 & 0.60 & & 0.3 & 1.20 & & 0.1 & 0.70 & \\
\hline $\begin{array}{l}\text { Child } \\
\text { Mortality }\end{array}$ & 0.2 & 1.43 & & -0.1 & .88 & & 0.0 & 0.52 & \\
\hline Nutrition & 0.7 & 2.40 & $* *$ & 0.3 & 1.24 & & 0.5 & 3.71 & $* * *$ \\
\hline Electricity & 0.1 & .63 & & 0.1 & .82 & & 0.1 & 1.41 & \\
\hline $\begin{array}{l}\text { Improved } \\
\text { Sanitation }\end{array}$ & 1.2 & 3.04 & $* * *$ & 0.4 & 2.02 & $* *$ & 0.8 & 4.09 & $* * *$ \\
\hline $\begin{array}{l}\text { Safe } \\
\text { Drinking } \\
\text { Water }\end{array}$ & 1.2 & 2.50 & $* *$ & 0.9 & 2.79 & $* * *$ & 1.1 & 5.77 & $* * *$ \\
\hline $\begin{array}{l}\text { Cooking } \\
\text { Fuel }\end{array}$ & 0.8 & 2.06 & $* *$ & 0.6 & 2.37 & $* *$ & 0.7 & 5.29 & $* * *$ \\
\hline Assets & -0.7 & 1.92 & $*$ & -0.7 & 1.92 & $*$ & -0.7 & 1.92 & $*$ \\
\hline
\end{tabular}

Note: *** statistically significant at $\alpha=0.01,{ }^{* *}$ statistically significant at $\alpha=0.05, *$ statistically significant at $\alpha=0.10$

\section{Cited References}

沈扬扬. (2012a). 经济增长与不平等对农村贫困的影响. 数量经济技术经济研究, vol. 8(16), p. 19.

沈扬扬. (2012b). 收入增长与不平等对农村贫困的影响——基于不同经济活动类型农户的研 究. 南开经济研究, vol. 2(20), p. 121.

陈辉, and 张全红. (2013). Alkire-Foster 模型测度城市多维贫困的研究——以广东省中山市 为例. 五邑大学学报 (自然科学版), vol. 2, 5 .

陈立中. (2008a). 转型时期我国多维度贫困测算及其分解. 经济评论, vol. 5, 6.

陈立中. (2008b). 收入、知识和健康的三类贫困测算与解析. 改革, vol. 3, 5. 
陈琦. (2012). 连片特困地区农村贫困的多维测量及政策意涵一一武陵山片区为例. 四川师 范大学学报（社会科学版）, vol. 39(3), p. 6.

陈宗胜, 沈扬扬, and 周云波. (2013). 中国农村贫困状况的绝对与相对变动——兼论贫困线 的设定. 管理世界, vol. 1, 11 .

丁建军. (2014). 多维贫困的理论基础、测度方法及实践进展. 西部论坛 (West Forum), vol. 24(1), p. 10.

范晨辉, 薛东前, and 马蓓蓓. (2015). Rasch 模型在多维贫困测度中的应用. 统计与决策, vol. 6, 3.

方迎风. (2012). 中国贫困的多维测度. 当代经济科学, vol. 34(4), p. 9.

郭建宇. (2012). 农户多维贫困程度与特征分析——基于山西农村贫困监测数据. 农村经济, vol. 3,4 .

郭建宇, and 吴国宝. (2012). 基于不同指标及权重选择的多维贫困测量一以山西省贫困县 为例. 中国农村经济, vol. 2, 9.

洪兴建. (2005). 贫困指数理论研究述评. 经济评论, vol. 5, 6 .

候卉, 王娜, and 王丹青. (2012). 中国城镇多维贫困的测度. 城市发展研究, vol. 12, pp. 123128.

蒋翠侠, 许启发, and 李亚琴. (2011). 中国家庭多维贫困的统计测度. 统计与决策, vol. 22, 4.

李飞. (2012). 多维贫困测量的概念、方法和实证分析——基于我国 9 村调研数据的分析. 广 东农业科学, vol. 9, 4.

李佳路. (2010). 农户多维度贫困测量——以 S 省 30 个国家扶贫开发工作重点县为例. 财贸 经济, vol. 10, 6.

李实, 沈扬扬, and 詹鹏. (2015). 清醒认识减贫成绩背后的问题. 国务院扶贫开发领导小组专 家咨询委员会研究交流信息第一期, vol. 1，6.

李小云, 李周, 唐丽霞, 刘永功, 王思斌, and 张春泰. (2005). 参与式扶贫指数的开发与验证. 中国农村经济, vol. 5.

林伯强. (2003). 中国的经济增长、贫困减少与政策选择. 经济研究, vol. 12, 10.

刘泽琴. (2012). 贫困的多维测度研究述评. 统计与决策, vol. 10, pp. 33-36.

罗楚亮. (2010). 农村贫困的动态变化. 经济研究, vol. 5, 16.

尚卫平, and 姚智谋. (2005). 多维贫困测度方法研究. 财经研究, vol. 31(12), p. 7.

世界银行, Ald, A., and ASTAE. (2013). 中国：加快居民清洁炊事和采暖的普及. Retrieved from

万广华, and 张藕香. (2008). 贫困按要素分解 : 方法与例证. 经济学 (季刊), vol. 3, 16.

万广华, and 张茵. (2006). 收入增长与不平等对我国贫困的影响. 经济研究, vol. 6, 12 . 
万广华, and 章元. (2009). 我们能够在多大程度上准确预测贫困脆弱性? . 数量经济技术经 济研究, vol. 6, 11 .

王小林, and Alkire, S. (2009). 中国多维贫困测量 : 估计和政策含义. 中国农村经济, vol. 12, 7. 王艳惠, 钱乐毅, and 段福洲. (2013). 县级多维贫困度量及其空间分布格局研究——以连片 特困区扶贫重点县为例. 地理科学, vol. 33(12), 1489-1497.

王祖祥, 范传强, and 何耀. (2006). 中国农村贫困评估研究. 管理世界, vol. 3, 7.

吴国宝. (1997). 谁是穷人. In 刘文璞 and 吴国宝 (Eds.), 地区经济增长和减缓贫困: 山西经济 出版社.

夏庆杰, 宋丽娜, and Appleton, S. (2010). 经济增长与农村反贫困. 经济学 (季刊), vol. 3, 20. 谢宇, 张晓波, and 李建新. (2014). 中国民生发展报告 2014: 北京大学出版社.

杨文, 孙蚌珠, and 王学龙. (2012). 中国农村家庭脆弱性的测量与分解. 经济研究, vol. 4, 12.

叶初升, and 王红霞. (2010). 多维贫困及其度量研究的最新进展 : 问题与方法. 湖北经济学 院学报, vol. 8(6), p. 6.

叶初升, and 赵锐. (2012). 村级贫困的度量 : 维度与方法. 发展经济学研究, vol. 1, 10.

叶普万. (2005). 贫困经济学研究: 一个文献综述. 世界经济, vol. 9, pp. 70-79.

叶普万. (2006). 贫困概念及其类型研究述评. 经济学动态, vol. 7, 3.

易红梅, and 张林秀. (2011). 农村最低生活保障政策在实施过程中的瞄准分析. 中国人口资 源与环境 (China Population, Resources and Environment), vol. 21(6), p. 8.

张建华, and 陈立中. (2006). 总量贫困测度研究述评. 经济学 (季刊), vol. 2, p. 20.

张林秀, 李强, 罗仁福, 刘承芳, and 罗斯高. (2005). 中国农村公共物品投资情况及区域分布. 中国农村经济, vol. 11, pp. 18-25.

张全红. (2015). 中国多维贫困的动态变化 : 1991-2011. 财经研究, vol. 41(4), p. 11.

张秀玲, 田国英, 潘云, 张振, and 张文丽. (2012). 中国农村居民贫困测度研究一一基于山西 的调查分析. 经济问题, 4, 6. doi:10.16011/j.cnki.jjwt.2012.04.016

中国国际扶贫中心. (2007). 中国农村反贫困政策综述. 见 : 张磊主编, 中国扶贫开发政策演 变：1949-2005 年。北京：中国财政经济出版社.

邹薇, and 方迎风. (2011). 关于中国贫困的动态多维度研究. 中国人口科学, vol. 6, 11.

邹薇, and 方迎风. (2012). 怎样测度贫困 : 从单维到多维. 国外社会科学, vol. 2, 7.

Addabbo, T., Di Tommaso, M. L., and Facchinetti, G. (2004). 'To what extent fuzzy set theory and structural equation modelling can measure functionings? an application to child well being', Materiali di Discussione del Dipartimento di Economia Politica 468, Modena.

Adelman, I., and Morris, C. T. (1973). Economic Growth and Social Equity in Developing Countries. Stanford: Stanford University Press. 
Ahluwalia, M. S. (1976). 'Inequality, poverty and development', Journal of Development Economics, 3(4), pp. 307-342.Ahluwalia, M. S. (2011). 'Prospects and policy challenges in the twelfth plan', Economic and Political Weekly, vol. 46(21), pp. 88-105.

Alkire, S. (2015). 'The capability approach and well-being measurement for public policy', OPHI Working Paper 94, University of Oxford.

Alkire, S., and Foster, J. (2011a). 'Counting and multidimensional poverty measurement', Journal of Public Economics, vol. 95(7), pp. 476-487.

Alkire, S., Foster, J. (2011b). 'Understandings and misunderstandings of multidimensional poverty measurement', Journal of Economic Inequality, vol. 9, pp. 289-314.

Alkire, S., Foster, J., Santos, M.E. (2011). 'Where did identification go?', The Journal of Economic Inequality, vol. 9, pp. 501-505,

Alkire, S., Foster, J., Seth, S., Santos, M. E., Roche, J. M., and Ballon, P. (2015). Multidimensional Poverty Measurement and Analysis. Oxford: Oxford University Press.

Alkire, S., Meinzen-Dick, R., Peterman, A., Quisumbing, A. R., Seymour, G., and Vaz, A. (2013). 'The women's empowerment in agriculture index', World Development, vol. 52, pp. 71-91.

Alkire, S. and Santos, M.E. (2014). 'Measuring Acute poverty in the developing world: robustness and scope of the multidimensional poverty index', (2014). World Development, vol. 259(7), pp. 251-274.

Alkire, S., and Seth, S. (2016). I'dentifying destitution through linked subsets of multidimensionally poor: an ordinal approach', OPHI Working Paper 99, University of Oxford.

Apablaza, N., and Yalonetzky, G. (2013). 'Decomposing multidimensional poverty dynamics', Young Lives Working Paper 101, University of Oxford.

Appleton, S. (1996). Women-headed households and household welfare: an empirical deconstruction for Uganda', World Development, vol. 24(12), 1811-1827.

Atkinson, A. B. (1992). 'Measuring poverty and differences in family composition', Economica, vol. 59(233), 1-16.

Azariadis, C., and Stachurski, J. (2005). 'Poverty traps', Handbook of Economic Growth, vol. 1, 295-384.

Bane, M. J., and Ellwood, D. T. (1983). Slipping into and out of Poverty: The Dynamics of Spells, Cambridge, MA: National Bureau of Economic Research.

Barrett, C. R., and Pattanaik, P. K. (1989). 'Fuzzy sets, preference and choice: some conceptual issues', Bulletin of Economic Research, vol. 41(4), pp. 229-254.

Beaulier, S. A., and Subrick, J. R. (2006). 'Poverty traps and the robust political economy of development assistance,' The Review of Austrian Economics, vol. 19(2-3), pp. 217-226.

Becker, G. S. (1995). 'Human capital and poverty alleviation. human resources development and operations policy', HRO Working Paper 52, The World Bank.

Bell, D. A. (2010). China's New Confucianism: Politics and Everyday Life in a Changing Society, Princeton: Princeton University Press.

Berg, S. V. D. (2008). 'Poverty and education', Education Policy Series 10, UNESCO. 
Bhalla, A. S., and Luo, D. (2012). Poverty and Exclusion of Minorities in China and India, New York: Palgrave Macmillan.

Bilenkisi, F., Gungor, M. S., and Tapsin, G. (2015). 'The impact of household heads' education levels on the poverty risk: the evidence from Turkey', Educational Sciences: Theory and Practice, vol. 15(2), pp. 337-348.

Bourguignon, F. (1989). 'Family size and social utility: income distribution dominance criteria', Journal of Econometrics, vol. 42(1), pp. 67-80.

Bourguignon, F. (2003). 'The growth elasticity of poverty reduction: explaining heterogeneity across countries and time-periods', in (T. Eichler and S. Turnovsky eds.), pp. 3-26, Growth and Inequality, Cambridge, MA: MIT Press.

Brown, P. H., and Park, A. (2002). 'Education and poverty in rural China', Economics of Education Review, vol. 21(6), pp. 523-541.

Buvinić, M., and Gupta, G. R. (1997). Female-headed households and female-maintained families: are they worth targeting to reduce poverty in developing countries?' Economic Development and Cultural Change, vol. 45(2), pp. 259-280.

Cerioli, A., and Zani, S. (1990). 'A fuzzy approach to the measurement of poverty', in (C. Dagum and Michele Zenga, eds.), Income and Wealth Distribution, Inequality and Poverty, pp. 272-284, Berlin and Heidelberg: Springer.

Chan, K. W., and Zhang, L. (1999). The hukou system and rural-urban migration in China: processes and changes', The China Quarterly, vol. 160, pp. 818-855.

Chen, S., and Ravallion, M. (2004). 'How have the worlds poorest fared since the early 1980s?' The World Bank Research Observer, vol. 19(2), pp. 141-69.

Chen, S., and Ravallion, M. (2008). 'China is Poorer than we thought, but no less successful in the fight against poverty', World Bank Policy Reseach Working Paper 5, The World Bank.

Chen, S., Ravallion, M., Galasso, E., Piazza, A., and Tidrick, G. (2005). 'Hidden impact? ex-post evaluation of an antipoverty program', Journal of Public Economics, vol. 89(11-12), p. 12.

Chenery, H. B., Ahluwalia, M. S., Bell, C. L. G., Duloy, J. H., and Jolly, R. (1974). Redistribution with Growth: An Approach to Policy, Oxford: Oxford University Press.

Cherng, H.-Y. S., and Hannum, E. (2013). 'Community poverty, industrialization, and educational gender gaps in rural China', Social Forces, vol. 92(2), p. 32.

Collicelli, C., and Valerii, M. (2000). 'A new methodology for comparative analysis of poverty in the Mediterranean: a model for differential analysis of poverty at a regional level', Economic Research Forum Working Paper 2023.

Corcoran, M., Duncan, G., Gurin, G., and Gurin, P. (1985). 'Myth and reality: the causes and persistence of poverty', Journal of Policy Analysis and Management, vol. 4(4), pp. 516-536.

Decancq, K., and Lugo, M. A. (2013). 'Weights in multidimensional indices of wellbeing: an overview', Econometric Reviews, vol. 32(1), pp. 7-34.

Deininger, K., and Squire, L. (1998). 'New ways of looking at old issues: inequality and growth', Journal of Development Economics, vol. 57(2), 259-287. 
Dellaportas, G. (1980). 'The effectiveness of public assistance payments in reducing poverty', American Journal of Economics and Sociology, vol. 39(2), pp. 113-121.

Demery, L., and Squir, L. (1996). 'Macroeconomic adjustment and poverty in Africa: an emerging picture', World Bank Research Observer, vol. 11, p. 21.

Deutsch, J., and Silber, J. (2005). 'Measuring multidimensional poverty: an empirical comparison of various approaches', Review of Income and Wealth, vol. 51(1), pp. 145-174.

Di Tommaso, M. L. (2007). 'Children capabilities: a structural equation model for India', The Journal of Socio-Economics, vol. 36(3), pp. 436-450.

Dollar, D., and Kraay, A. (2002). 'Growth is good for the poor', Journal of Economic Growth, vol. 7(3), p. 31.

Dollar, D., and Kraay, A. (2004). 'Trade, growth, and poverty', The Economic Journal, vol. 114(493), F22-F49.

Du, Y., Park, A., and Wang, S. (2005). 'Migration and rural poverty in China', Journal of Comparative Economics, vol. 33, p. 22.

Duclos, J.-Y., Araar, A., and Giles, J. (2010). 'Chronic and transient poverty: measurement and estimation, with evidence from China', Journal of Development Economics, vol. 91(2), pp. 12.

Duclos, J.-Y., and Tiverti, L. (2014). Multidimensional Poverty Indices: A Critical Assessment.

Efron, B. (1979).'Bootstrap methods: another look at the jackknife', Annals of Statistics, vol. 7(1), pp. $1-26$.

Filmer, D. (2000). 'The structure of social disparities in education: gender and wealth', Worldbank Policy Reseach Working Paper, The World Bank.

Filmer, D. (2005). 'Disability, poverty, and schooling in developing countries: results from 11 household surveys', World Bank Policy Research Working Paper 3794, The World Bank.

Gao, Q., Garfinkel, I., and Zhai, F. (2009). 'Anti-poverty effectiveness of the minimum living standard assistance policy in urban China', The Review of Income and Wealth, vol. 55(1), p. 26.

Ge, J., and Lei, Y. (2013). 'Mining development, income growth and poverty alleviation: a multiplier decomposition technique applied to China', Resources Policy, vol. 38(3), p. 10.

Gottschalk, P., and Danziger, S. (1993). 'Family structure, family size, and family income: accounting for changes in the economic well-being of children, 1968-1986' in (S. Danziger and P.Gottschalk, eds.), Uneven Tides: Rising Inequality in America.

Gustafsson, B., and Sai, D. (2009). 'Temporary and persistent poverty among ethnic minorities and the majority in rural China', Review of Income and Wealth, vol. 55(s1), pp. 588-606.

Gustafsson, B., and Shi, L. (2003). 'The ethnic minority - majority income gap in rural China during transition', Economic Development and Cultural Change, vol. 51(4), pp. 805-822.

Hannum, E. (2005). 'Market transition, educational disparities, and family strategies in rural China: new evidence on gender stratification and development', Demography, vol. 42(2), 275-299.

Hannum, E., and Xie, Y. (1998). 'Ethnic stratification in Northwest China: occupational differences between Han Chinese and national minorities in Xinjiang, 1982-1990', Demography, vol. 35(3), pp. 323-333. 
Iceland, J. (2003). 'Why poverty remains high: the role of income growth, economic inequality, and changes in family structure, 1949-1999', Demography, vol. 40(3), pp. 499-519.

Jackson, C. (1996). 'Rescuing gender from the poverty trap', World Development, vol. 24(3), pp. 489504.

Jalan, J., and Ravallion, M. (1998). Transient Poverty in post-reform rural China', Journal of Comparative Economics, vol. 26(2), p. 20.

Jalan, J., and Ravallion, M. (2002). 'Geographic poverty traps? a micro model of consumption growth in rural China', Journal of Applied Econometrics, vol. 17(4), p. 18.

Keister, L. A. (2008). 'Conservative Protestants and wealth: how religion perpetuates asset poverty', American Journal of Sociology, vol. 113(5), pp. 1237-1271.

Knight, J., Lina, S., and Gunatilaka, R. (2009). 'Subjective well-being and its determinants in rural China', China Economic Review, vol. 20(4), pp. 635-649.

Knight, J., and Song, L. (2000). 'Differences in educational access in rural China', mimeo, Department of Economics, University of Oxford.

Kuang, L., and Liu, L. (2012). 'Discrimination against rural-to-urban migrants: the role of the Hukou system in China', PloS one, vol. 7(11).

Kyereme, S. S., and Thorbecke, E. (1991). 'Factors affecting food poverty in Ghana', The Journal of Development Studies, vol. 28(1), pp. 39-52.

Lelli, S. (2001). 'Factor analysis vs. fuzzy sets theory: assessing the influence of different techniques on sen's functioning approach', Public Economics Working Series, Catholic University, Leuven.

Lewis, O. (1966). La Vida: A Puerto Rican Family in the Culture of Poverty-San Juan and New York (Vol. 13), New York: Random House.

Li, S. (2014). 'Poverty reduction and effects of pro-poor policies in rural China', China and World Economy, vol. 22(2), p. 20.

Li, S., and Sicular, T. (2014). 'The distribution of household income in China: inequality, poverty and policies', The China Quarterly, vol. 217(1), pp. 1-41..

Liu, Z. (2005). 'Institution and inequality: the hukou system in China', Journal of Comparative Economics, vol. 33(1), pp. 133-157.

Lusting, N. (2011). 'Multidimensional indices of achievements and poverty: what do we gain and what do we lose?', Journal of Economic Inequality, vol. 9(2), pp. 227-234.

Luzzi, G. F., Flückiger, Y., and Weber, S. (2008). A Cluster Analysis of Multidimensional Poverty in Switzerland. Berlin: Springer.

McLanahan, S. (1985). 'Family structure and the reproduction of poverty', American Journal of Sociology, vol. 90(4), pp. 873-901.

Meng, L. (2013). 'Evaluating China's poverty alleviation program: a regression discontinuity approach', Journal of Public Economics, vol. 101, pp. 1-11.

Montalvo, J. G., and Ravallion, M. (2010). 'The pattern of growth and poverty reduction in China', Journal of Comparative Economics, vol. 38(1), 15. 
Montgomery, J. L. (2012). 'Inheritance of inequality: hukou and related barriers to compulsory education for China's migrant children', Pacific Rim Law and Policy Journal., vol. 21, 591-622.

Naga, R. A., and Bolzani, E. (2008). 'Income, consumption and permanent income: a mimic approach to multidimensional poverty measurement' in (N. Kakwani and J. Silber, eds.), Quantitative Approaches to Multidimensional Poverty Measurement, pp. 104-117, Basingstoke: Palgrave-Macmillan.

Narayan, D., Pritchett, L., and Kapoor, S. (2009). Moving Out of Poverty: Success from the Bottom Up: Palgrave and World Bank.

Okojie, C. E. (2002). Gender and Education as Determinants of Housebold Poverty in Nigeria: WIDER Discussion Papers//World Institute for Development Economics (UNU-WIDER).

Park, A., and Wang, D. (2010). Migration and Urban Poverty and Inequality in China. China Economic Journal, 3(1), 19.

Park, A., and Wang, S. (2010). Community-based Development and Poverty Alleviation: An Evaluation of China's Poor Village Investment Program. Journal of Public Economics, 94(9), 10.

Park, A., Wang, S., and Wu, G. (2002). Regional Poverty Targeting in China. Journal of Public Economics, 86(1), 31.

Pearce, D. (1978). The Feminization of Poverty: Women, Work, and Welfare. The Urban and Social Change Review, 11(1-2), 11.

Perry, E. J., and Selden, M. (2003). Chinese Society: Change, Conflict and Resistance: Routledge.

Pogge, T., and Wisor, S. (Eds.). (2014). Measuring Poverty: A Proposal.

Ram, R. (1982). Composite Indices of Physical Quality of Life, Basic Needs Fulfilment, and Income: A 'Principal Component' Representation. Journal of Development Economics, 11(2), 227-247.

Ravallion, M. (2005). Evaluating Anti-poverty Programs. Handbook of Development Economics, 4, 59.

Ravallion, M. (2011a). A Comparative Perspective on Poverty Reduction in Brazil, China, and India. The World Bank Research Observer, 26(1), 34.

Ravallion, M. (2011b). On Multidimensional Indices of Poverty. The Journal of Economic Inequality, 9(2), 235-348.

Ravallion, M., and Chen, S. (2007). China's (uneven) Progress Against Poverty. Journal of Development Economics, 82, 42.

Ravallion, M., and Jalan, J. (1999). China's Lagging Poor Areas. American Economic Review, 89(2), 5.

Ravallion, M., and Jalan, J. (2000). Is Transient Poverty Different? Evidence for Rural China. Journal of Development Studies, 36(6), 18.

Ren, Q., and Treiman, D. J. (2013). The Consequences of Parental Labor Migration in China for Children's Emotional Well-being. Paper presented at the Poster presented at the annual meeting of the Population Association of America, New Orleans, April.

Riskin, C. (1994). Chinese Rural Poverty: Marginalized or Dispersed? The American Economic Review, 84(2), 4.

Rozelle, S., Park, A., Benziger, V., and Changqi, R. (1998). Targeted Poverty Investments and Economic Grwoth in China. World Development, 26(12), 15. 
Sen, A. (1989). Development as Capability Expansion. Journal of Development Planning, 19, 18.

Sen, A. (1999). Development as Freedom (1 ${ }^{\text {st }}$ ed.), Oxford University Press.

Seth, S., and Alkire, S. (2014). Did Poverty Reduction Reach the Poorest of the Poor? Assessment Methods in the Counting Approach. OPHI Working Paper77.

Smith, J. P. (1988). Poverty and the Family. Divided opportunities: Minorities, poverty, and social policy, 141-172.

Swidler, A. (1986). Culture in Action: Symbols and Strategies. American sociological review, 273-286.

Thorat, S., and Fan, S. (2007). Public Investment and Poverty Reduction: Lessons from China and India. Economic and Political Weekly, 42(8), 7.

Tsui, K.-Y. (2002). Multidimensional Poverty Indices. Social Choice and Welfare, 19, 27.

UNDP. (2013). China's Progress towards the Millennium development Goals 2013 Report. UNDP China 2013 Report.

Varley, A. (1996). Women Heading Households: Some More Equal than Others? World Development, 24(3), 505-520.

Waglé, U. R. (2008). Multidimensional Poverty: An Alternative Measurement Approach for the United States? Social Science Research, 37(2), 559-580.

Wang, S. (2005). Poverty Targeting in the People's Republic of China. In: Weiss, J. (Ed.), Poverty Targeting in Asia. Edward Elgar, Cheltenham, United Kingdom.

Wang, X., Feng, H., Xia, Q., and Alkire, S. (2016). On the Relationship between Income Poverty and Multidimensional Poverty in China. OPHI Working Paper No.101.

Whitehead, A., and Kabeer, N. (2001). Living with Uncertainty: Gender, Livelihoods and Pro-poor Growth in Rural Sub-Saharan Africa. Brighton: Brighton : Institute of Development Studies, University of Sussex.

WorldBank. (1999). Strategic Goals for Chinese Education in the 21st Century. The World Bank, Washington, D.C.

WorldBank. (2001). China: Overcoming Rural Poverty. The World Bank, Washington, D.C.

Wu, Q., Dai, L., Cui, Y., Zhang, W., Zhang, C., Chen, J., Xie, Y. (2015). Supplement to the User's Manual for the 2010 CFPS Data.

Xie, Y., and Zhou, X. (2014). Income Inequality in Today's China. PNAS, 111(19), 6.

Xu, H., and Xie, Y. (2013). The Causal Effects of Rural-to-Urban Migration on Children's Wellbeing in China. Paper presented at the 2013 Population Association of America Annual Meeting,, New Orleans (April).

Yang, M. (2003). China's Rural Electrification and Poverty Reduction. Energy Policy, 31(3), 13.

Yao, S. (2000). Economic Development and Poverty Reduction in China over 20 Years of Reforms. Economic Development and Cultural Change, 48(3), 28.

Young, J. (2013). China's Hukou System: Markets, Migrants and Institutional Change: Palgrave Macmillan. 
Yu, J. (2013). Multidimensional Poverty in China: Findings Based on the CHNS. Social Indicators Research, 112(2), 22.

Zhang, C., Xu, Q., Zhou, X., Zhang, X., and Xie, Y. (2013). An Evaluation of Poverty Prevalence in China: New Evidence from Four Recent Surveys. IFPRI Discussion Paper 01293, 28.

Zhang, C., Xu, Q., Zhou, X., Zhang, X., and Xie, Y. (2014). Are Poverty Rates Underestimated in China? New evidence from Four Recent Surveys. China Economic Review, 31(16), 410.

Zhang, D., Li, X., and Xue, J. (2015). Education Inequality between Rural and Urban Areas of the People's Republic of China, Migrants' Children Education, and Some Implications. Asian Development Teview, 32(1), 196-224.

Zhang, H. (2010). The Hukou System's Constraints on Migrant Workers' Job Mobility in Chinese Cities. China Economic Review, 21(1), 51-64.

Zhang, J., and Smith, K. R. (2005). Indoor Air Pollution from Household Fuel Combustion in China: A Review Proceedings of the 10th International Conference on Indoor Air Quality and Climate (pp. 65-83). Beijing: Tsinghua University Press. 